\title{
Pilot Testing of a Geomorphic Landform Design Reclamation Using a Vegetative Layer with Short Paper Fiber Amendment on an Abandoned Coal Refuse Pile in Appalachia
}

Levi Cyphers

Follow this and additional works at: https://researchrepository.wvu.edu/etd

\section{Recommended Citation}

Cyphers, Levi, "Pilot Testing of a Geomorphic Landform Design Reclamation Using a Vegetative Layer with Short Paper Fiber Amendment on an Abandoned Coal Refuse Pile in Appalachia" (2018). Graduate Theses, Dissertations, and Problem Reports. 5427.

https://researchrepository.wvu.edu/etd/5427

This Thesis is protected by copyright and/or related rights. It has been brought to you by the The Research Repository @ WVU with permission from the rights-holder(s). You are free to use this Thesis in any way that is permitted by the copyright and related rights legislation that applies to your use. For other uses you must obtain permission from the rights-holder(s) directly, unless additional rights are indicated by a Creative Commons license in the record and/ or on the work itself. This Thesis has been accepted for inclusion in WVU Graduate Theses, Dissertations, and Problem Reports collection by an authorized administrator of The Research Repository @ WVU. For more information, please contact researchrepository@mail.wvu.edu. 


\title{
Pilot testing of a Geomorphic Landform Design reclamation using a vegetative layer with short paper fiber amendment on an abandoned coal refuse pile in Appalachia
}

\author{
Levi J. Cyphers \\ Thesis submitted to the \\ Benjamin M. Statler College of Engineering and Mineral Resources \\ West Virginia University \\ in partial fulfillment of the requirements \\ for the degree of \\ Master of Science in \\ Civil and Environmental Engineering \\ Dr. Leslie Hopkinson, Ph.D., Chair \\ Dr. John Quaranta, Ph.D. \\ Dr. Seung Ho Hong, Ph.D. \\ Department of Civil and Environmental Engineering \\ Morgantown, West Virginia \\ 2018
}

Keywords: Surface mine reclamation, land reclamation, coal refuse reclamation, short paper fiber, establishing vegetation

Copyright 2018 Levi Cyphers 


\section{Abstract
Pilot testing of a Geomorphic Landform Design reclamation using a vegetative layer with short paper fiber amendment on an abandoned coal refuse pile in Appalachia

\section{Levi J. Cyphers}

Over 3,000 abandoned mine lands in the Appalachian regions of West Virginia, Pennsylvania, and Kentucky and are in need of reclamation. This research tested an alternative cap and cover reclamation design using short paper fiber as a soil amendment in a coarse coal refuse vegetation layer. Short paper fiber is the solid residuals extracted from the paper manufacturing process, and treated as waste. Short paper fiber is a nutrient dense material that has been successfully tested as a soil amendment in soils. The intent of the vegetation layer was to support grass growth and persistence, stabilize the site, and reduce acid mine drainage (AMD).

First, a 0.28 acre field site was designed to demonstrate and test geomorphic reclamation features in Appalachia. The field site was composed of three test plots (60\% refuse with $40 \%$ paper fiber, $80 \%$ refuse with $20 \%$ paper fiber, $100 \%$ refuse) that centrally drained into a geomorphic channel. A hydraulic barrier composed of compacted refuse and slopes up to $2 \mathrm{H}: 1 \mathrm{~V}$ were included. Construction was completed September 2017 and the site was monitored (i.e. vegetation ground cover, infiltration of vegetation layer and hydraulic barrier, compaction, surface runoff water quality, and surface temperature). The constructability of the site was also studied to identify suitable construction methods during the final reclamation of the full site.

Vegetation ground cover reached a maximum of $29.4 \%$ in the plot with $20 \%$ paper fiber. Infiltration of the refuse was reduced $30.5 \%$ in the hydraulic barrier of the plots containing paper fiber from the in situ material, despite not meeting the $95 \%$ required compaction density. Surface temperature varied $11^{\circ} \mathrm{C}$ across the plots, affecting grass germination. Though a longer duration of monitoring is needed, preliminary findings show that the mixture ratio containing $20 \%$ short paper fiber outperformed the mixture ratio containing $40 \%$ paper fiber. Reducing short paper fiber for the growth layer means additional savings in the cost of the final reclamation. 


\section{Grant Information}

The work described in this publication was supported by Grant/Cooperative Agreement Number S15AC20020 from the Office of Surface Mining, Reclamation, and Enforcement. Its contents are solely the responsibility of the authors and do not necessarily represent the official views of the OSM. This work is also in collaboration with the West Virginia Department of Environmental protection. 


\section{Acknowledgements}

I would like to take a second to show thanks for the support I have received while completing this master's program. I am appreciative of the help Dr. Leslie Hopkinson, Dr. John Quaranta, and Dr. Seung Ho Hong for the research advising received while serving on my committee. To Iuri, for his help in many days of data collection and hours spent driving, and willingness to help out in any way. To Justin and Russell, for endless advice and assistance on any task. To my family, who provided encouragement when needed, and always made sure I never went without.

Thank you to Nathan Parks and Jeff Johnson, and the rest of the WVDEP for providing this opportunity for research, and their cooperation throughout the duration of this project. 


\section{Table of Contents}

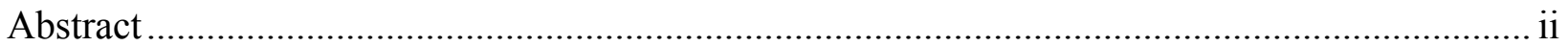

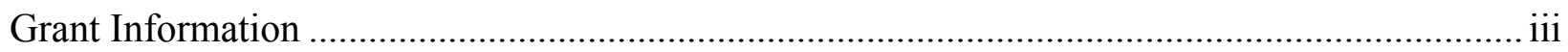

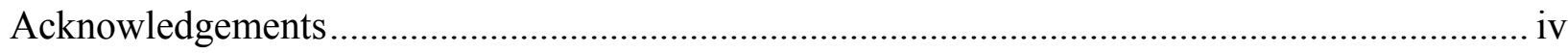

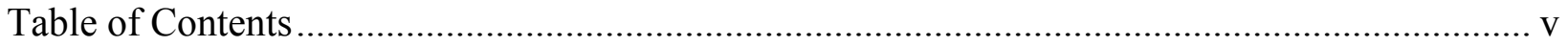

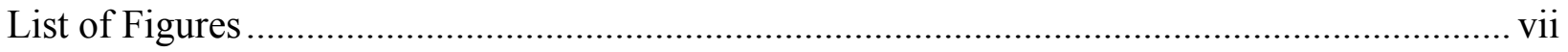

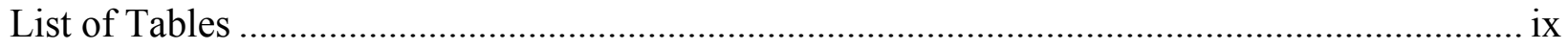

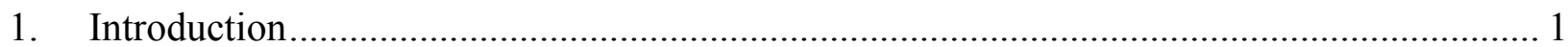

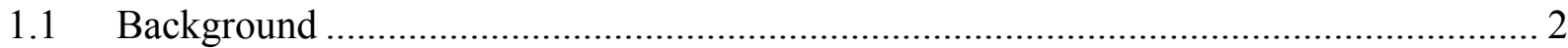

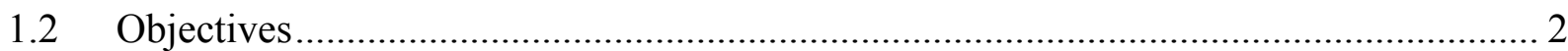

2. Literature Review: Cap and cover systems for mine reclamation ................................... 4

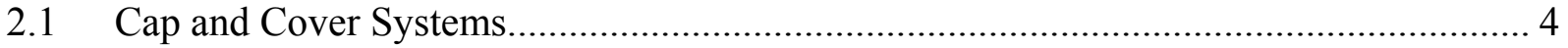

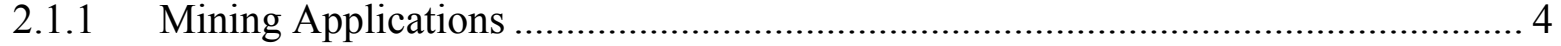

2.1.2 Conventional Waste Disposal .............................................................................. 5

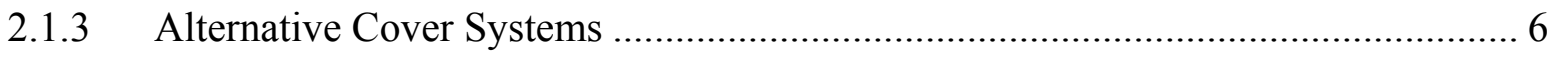

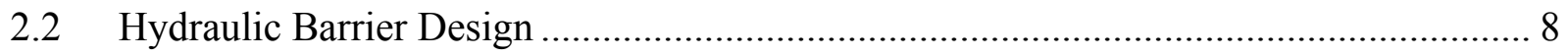

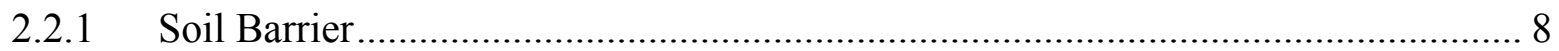

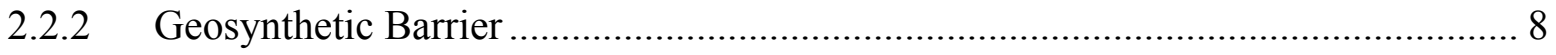

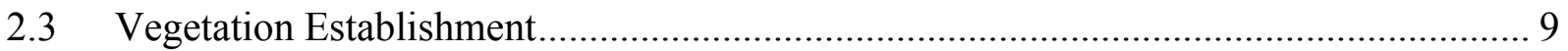

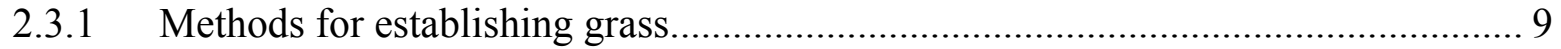

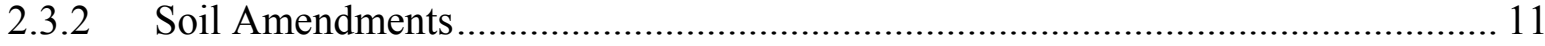

2.3.3 Short Paper Fiber .................................................................................. 12

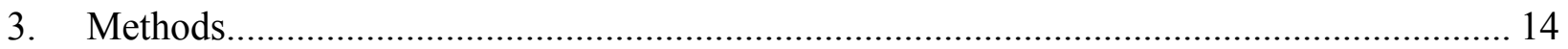

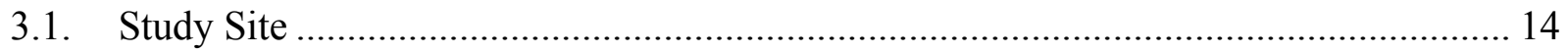

3.2. Features of full-scale design under evaluation................................................. 15

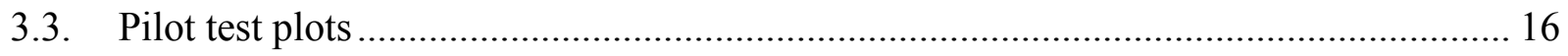

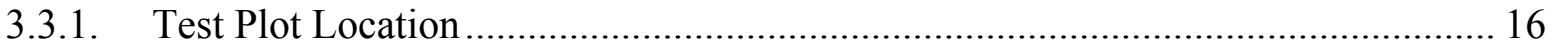

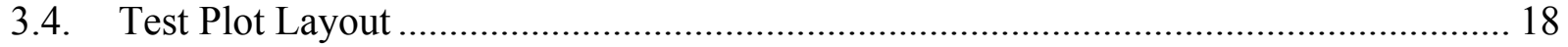

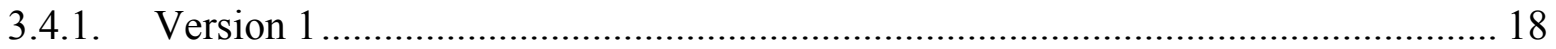

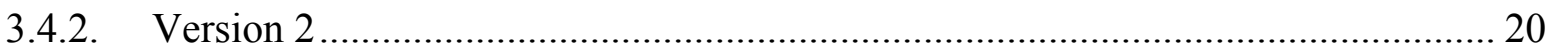




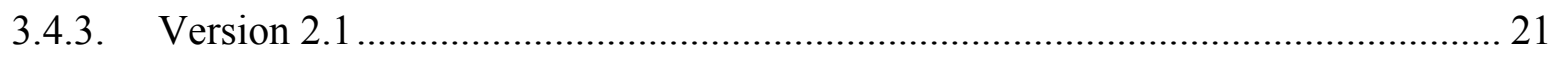

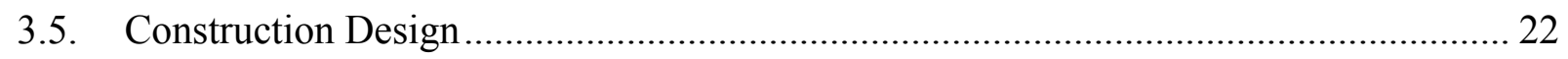

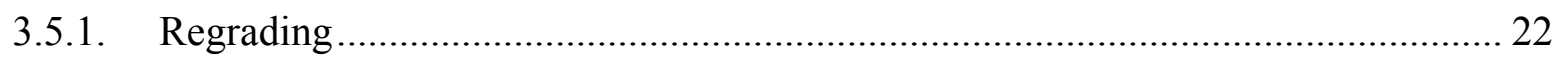

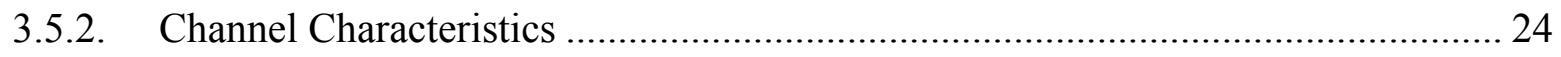

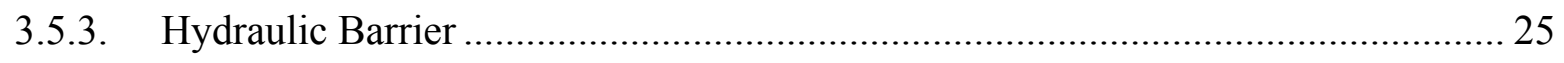

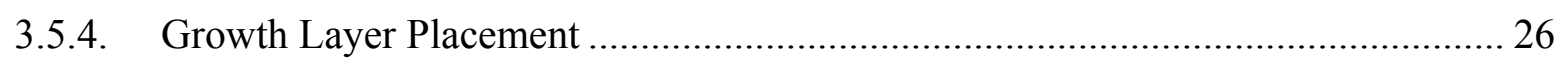

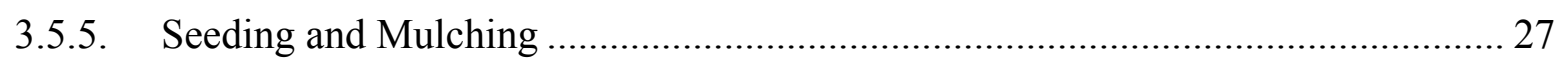

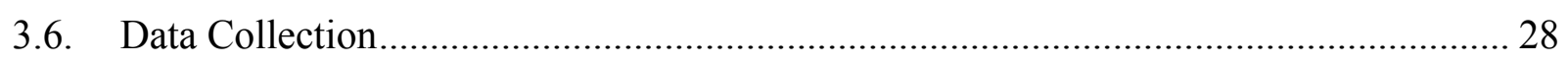

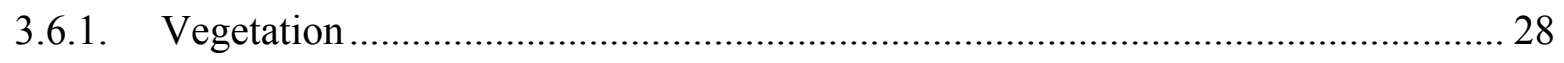

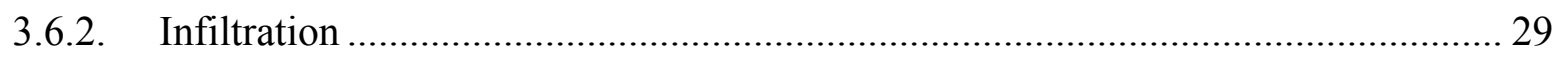

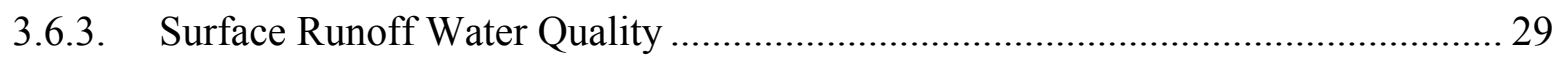

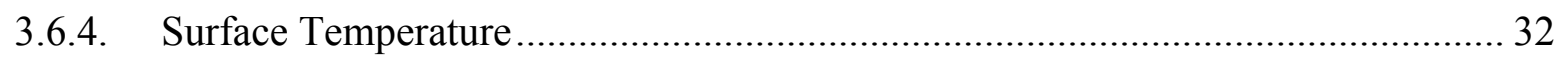

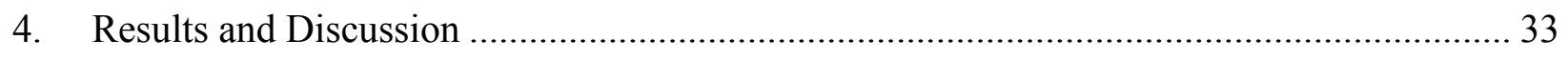

4.1 Field Site Construction and Completion ………………........................................ 33

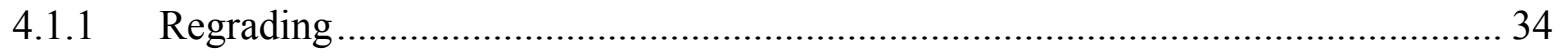

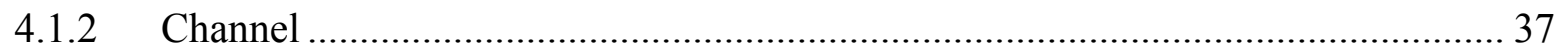

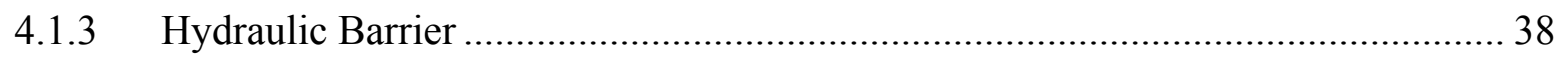

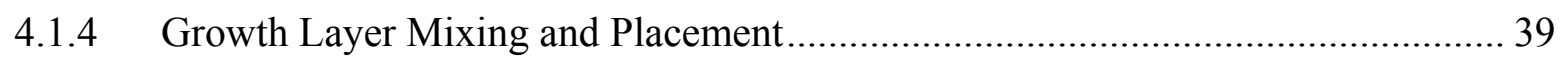

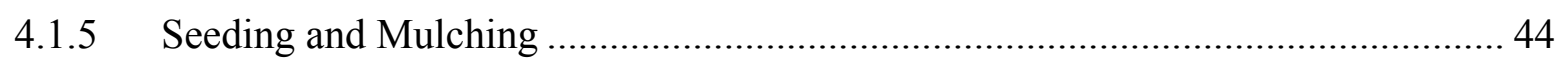

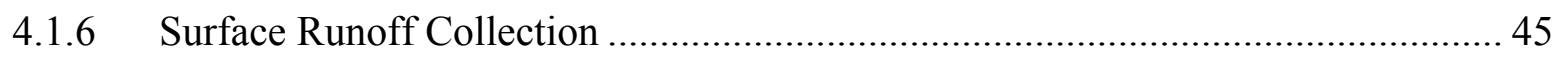

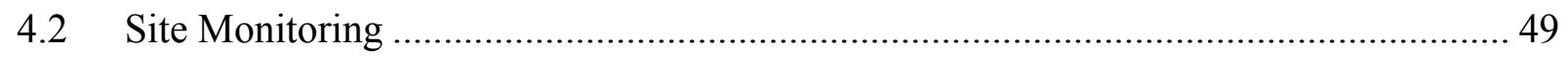

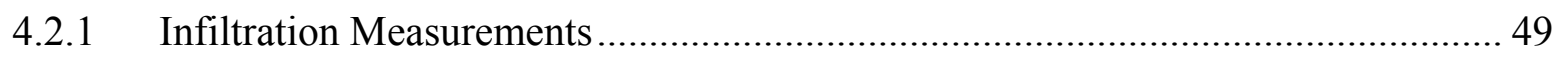

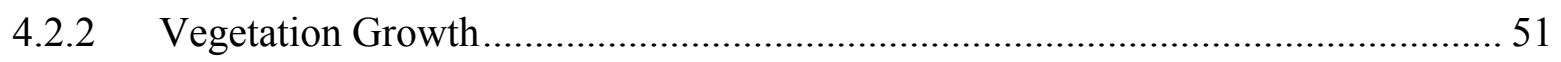

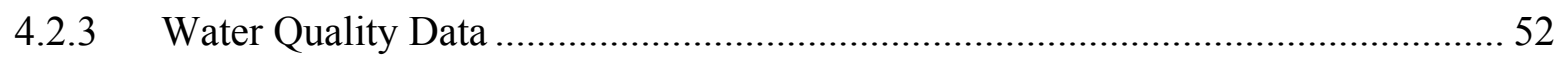

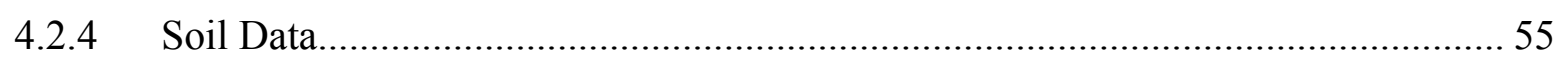

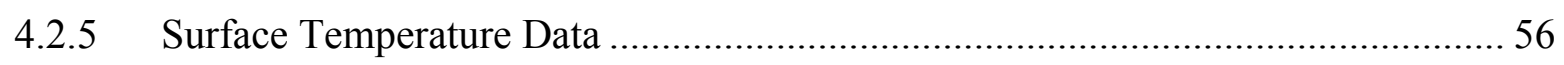

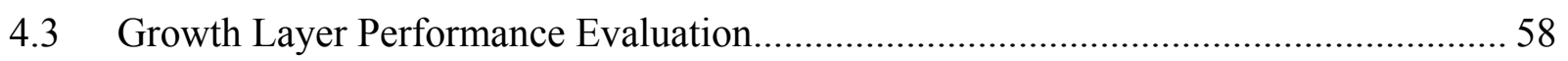

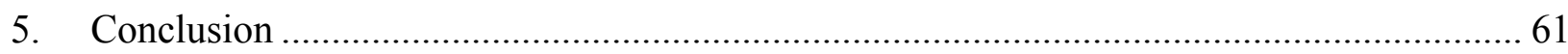

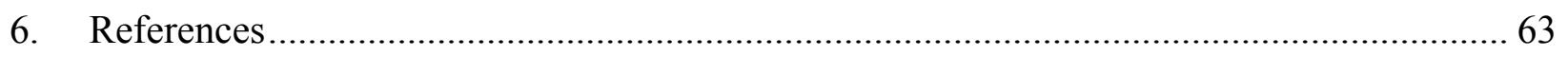

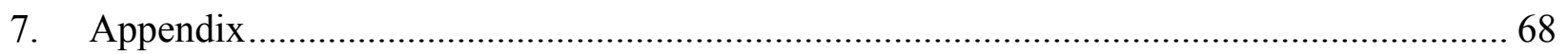

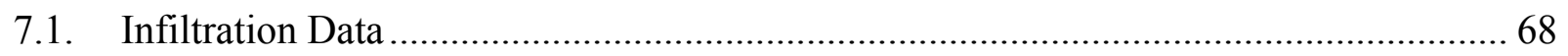

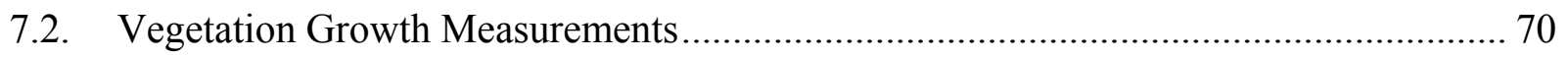

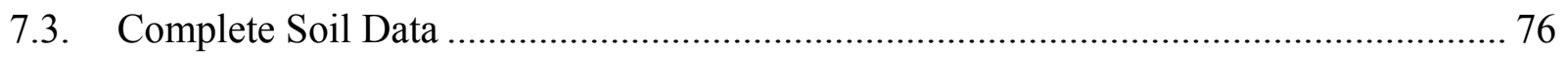




\section{List of Figures}

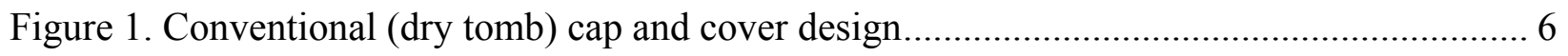

Figure 2. Alternative (water balance) cover design ................................................................. 8

Figure 3. Royal Scot coarse coal refuse pile Greenbrier County, WV ......................................... 15

Figure 4. Test plot location on Royal Scot refuse site ............................................................... 17

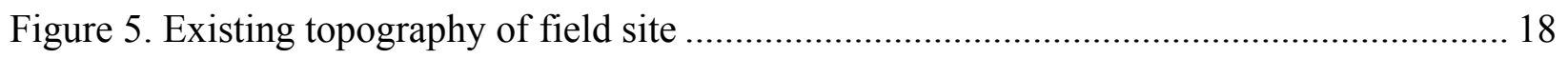

Figure 6. First version of Royal Scot test plot layout ............................................................... 19

Figure 7. Second version of Royal Scot test plot layout............................................................. 21

Figure 8. Test plot layout design chosen for Royal Scot reclamation ........................................ 22

Figure 9. Conceptual 3D layout of proposed test plot surface (no vertical exaggeration) ........... 23

Figure 10. Cut and fill map for proposed test plots ............................................................... 24

Figure 11. Geomorphic channel design (adapted from Hopkinson et al., 2017) .......................... 25

Figure 12. Cross sectional view of layout with hydraulic barrier.............................................. 26

Figure 13. a) device for measuring vegetation ground cover b) double grid design on ground

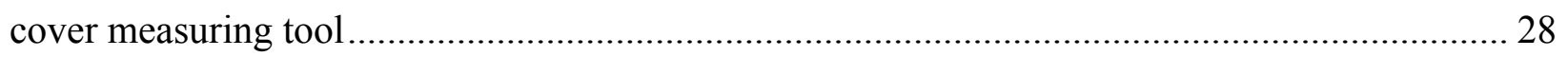

Figure 14. Infiltrometer for determining infiltration rates of soil media ................................... 29

Figure 15. a) Constructing surface runoff collector b) Assembling runoff collector .................... 30

Figure 16. Completed construction of surface runoff collector................................................. 30

Figure 17. 15 surface runoff collectors for field application ..................................................... 31

Figure 18. Screen added to runoff collectors for large particle filtration ...................................... 31

Figure 19. Infrared thermometer for ground surface temperatures........................................... 32

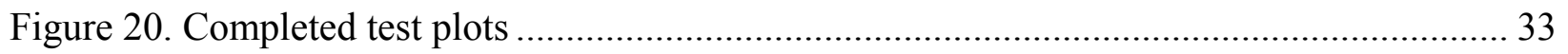

Figure 21. Topographical view of test plots (2-ft contour intervals) ........................................ 34

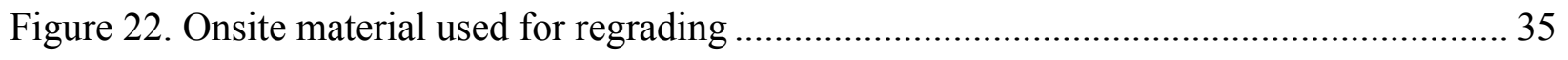

Figure 23. Final survey data modeled in Civil 3D (no vertical exaggeration) ............................. 35

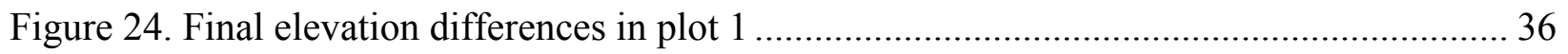

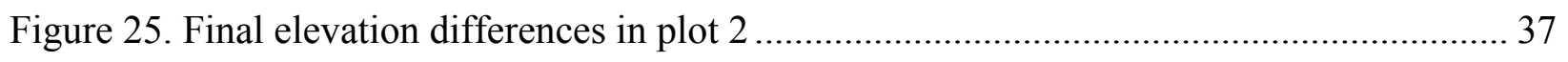

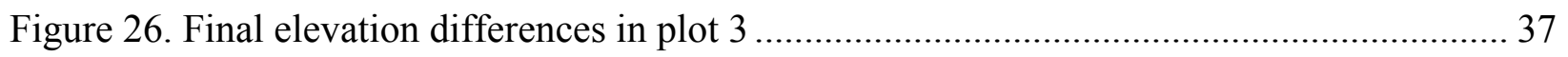

Figure 27. Gravel placement in geomorphic channel ……....................................................... 38

Figure 28. Spreading paper fiber for growth layer ................................................................. 40 
Figure 29. Unsuccessful blending of growth layer materials ...................................................... 41

Figure 30. Scraping the growth layer for better blending ........................................................ 41

Figure 31. Second failed attempt of growth layer mixing ....................................................... 42

Figure 32. Bucket quantities to ensure correct mix ratios ..................................................... 43

Figure 33. Mixing growth layer materials with excavator bucket teeth ...................................... 43

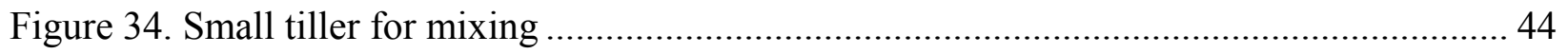

Figure 35. Hydroseeding application of seed and mulch (courtesy of Nathan Parks, WVDEP) . 45

Figure 36. Survey location of each collector (2-ft contour intervals)......................................... 46

Figure 37. Water collectors placed in low areas to maximize sample volume............................... 46

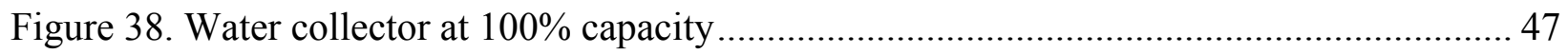

Figure 39. Water collector entirely filled and covered by coal refuse sediment .......................... 48

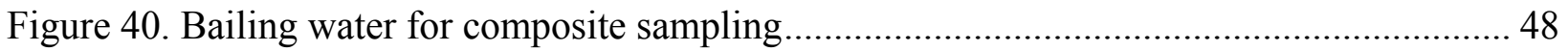

Figure 41. Grab sample from ponding within channel .............................................................. 49

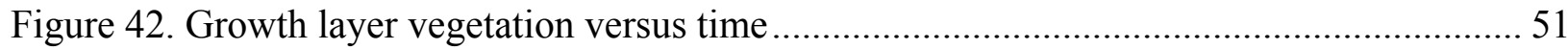

Figure 43. Snow melt showing evidence of unequal surface temperatures .................................. 58

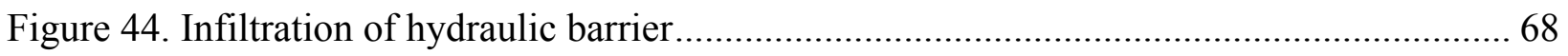

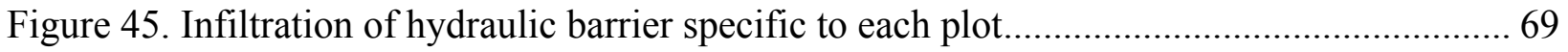

Figure 46. Infiltration of growth layers compared to pre-disturbance refuse ................................ 69 


\section{List of Tables}

Table 1. Summary of layout variants ............................................................................. 20

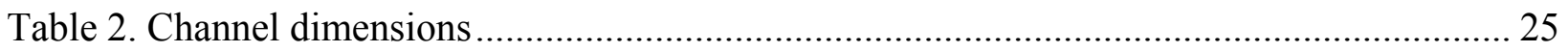

Table 3. Quantities for mixture based on equipment bucket sizes ........................................ 27

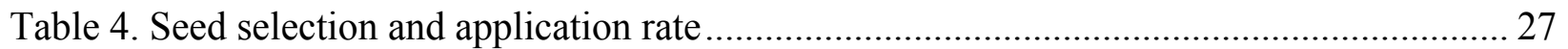

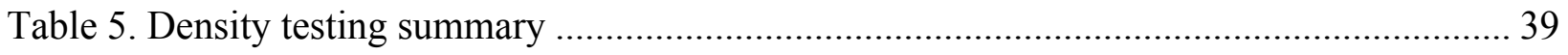

Table 6. Hydraulic barrier infiltration across all plots ........................................................... 50

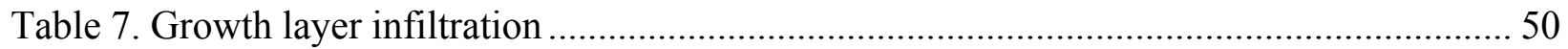

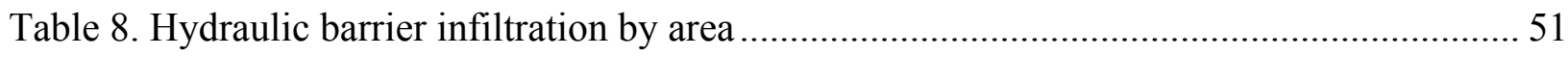

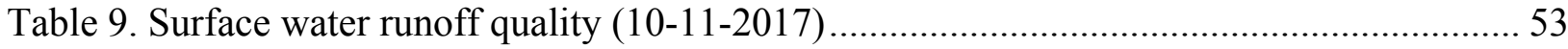

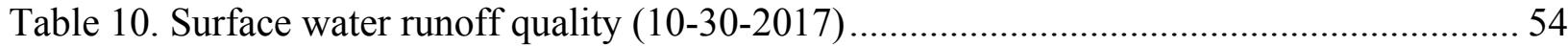

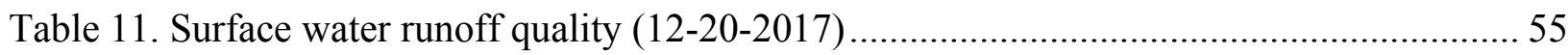

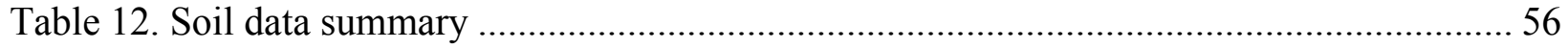

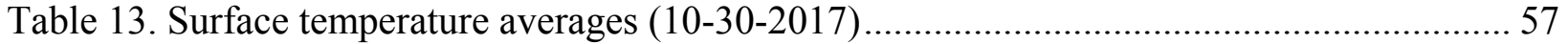

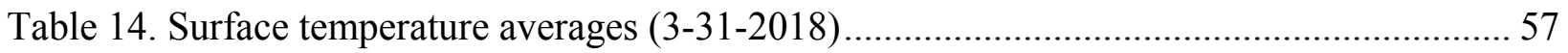




\section{Introduction}

Coal mining is a major economic factor in much of the Appalachian mountain region, providing jobs and support for state funding such as that in West Virginia. As mineral demand may cycle, the need for cleaner removal processes stay constant. As years pass and more coal is extracted through underground or surface mining, water pollution in local streams and rivers becomes increasingly worse. Acid Mine Drainage (AMD) is produced when sulfide bearing material is exposed to oxygen and water. This process occurs naturally but mining increases AMD generation simply by increasing the quantity of sulfides exposed (Akcil and Koldas, 2006).

Surface mining can generate a large amount of unusable material, and overburden, by removal to reach the mineral to be extracted. On some occasions, overburden can be backfilled to replace the void left from mineral extraction as a feasible and desirable part of reclamation requirements (Darling, 2011). Other times the refuse piles are not properly reclaimed after mining. Overburden and spoil piles, and tailings dams have the potential to be extremely acidic and contribute to AMD generation (Akcil and Koldas, 2006).

Reclamation is a necessary step for responsible post-mining activities in an effort to lessen the impact the exposed minerals will have on the environment. Surface mine reclamation in West Virginia must also adhere to additional procedures such as stabilizing all backfilled material for future uses capable to that of conditions prior to mining and of the original contours, to cover all acid forming and other toxic materials, restore initially removed topsoil to cover backfill and to support a diverse and effective permanent vegetation, and to cover all spoil in excess of that needed to restore the land to its original contours to the same standards of the mine itself (Daniels et al., 2004).

The role of vegetation on regraded slopes is to increase slope stability, increase water runoff, and decrease erosion (Novotny, 2003). Because of the large, heavy equipment used in reclamation, soil becomes more compact than in its natural state. This increased compaction results in decreased porosity and infiltration (Chong et al., 1986). With additional absorption of water into plant roots and runoff due to decreased soil surface area combined with the slower infiltration rates of the compacted soil, less AMD will be generated when two of the components of AMD (water and oxygen) are eliminated from the sulfide minerals. 
With the large number of mine lands in Appalachia in need of reclamation, low cost alternatives are needed to increase the number of abandoned mine lands reclaimed each year. An abandoned mine site in southern West Virginia provides an opportunity to test an alternative cap and cover design with possibilities of providing a new mine land reclamation strategy.

\subsection{Background}

The field site chosen for the study is a coal refuse pile in Greenbrier County, West Virginia. The site is home to a former surface mine in operation until 1993 when the Leckie Smokeless Coal Company declared bankruptcy. The land then switched hands when Royal Scot Minerals bought the operation out of bankruptcy before they also went bankrupt (Ward, 2001). The site is now in control of the West Virginia Department of Environmental Protection (WVDEP) who treats the 40+-acre pile for the AMD it generates. In its first few years, treatment cost more than $\$ 220,000$ in chemicals for treatment annually (Ward, 2001). The refuse pile was mostly unable to establish any vegetation which has caused erosion in many areas. The waste was randomly placed with no final grade or compactive effort.

The reclamation effort has been completed by West Virginia University utilizing a method of land reconstruction known as Geomorphic Land Design (GLD or landforming). Landforming is the adoption of curvilinear compound slopes that blend well with the surrounding physiography and represent naturally stabilizing geomorphic process (Michael et al., 2010). Slopes become more resistive to erosive forces increasing the long-term establishment of vegetation. Interest in the Appalachian region has been slow to develop compared to other parts of the country because of the challenges faced in extra-time and skill required for an uneconomical reclamation in steep terrain (Michael et al., 2010)

\subsection{Objectives}

The main objective of this research is to design, implement, and monitor a pilot test design of the GLD cap and cover system on the Royal Scot site in Greenbrier County. The test design and procedure was completed in cooperation with the WVDEP in the following steps:

1. Site selection and surveying,

2. Test plots design,

3. Test plots construction,

4. Vegetation growth, water quality, infiltration, and slope design integrity monitoring of the cap and cover design, and 
5. Find the most effective technique for growth layer placement of the full site reclamation. 


\section{Literature Review: Cap and cover systems for mine reclamation}

\subsection{Cap and Cover Systems}

Cap and cover systems are used in applications such as municipal waste, hazardous waste, and industrious waste where a product or by-product has no other known use and must responsibly be disposed of. The U.S. Environmental Protection Agency (USEPA) regulates waste through a federal law called the Resource Conservation and Recovery Act (RCRA). RCRA outlines management practices to sources that generate waste categorized as hazardous, municipal, or industrial, and the proper procedure to dispose of it. The nature of disposal being generally large volumes of material is that waste can quickly turn hazardous to the environment when improperly handled and introduced to decomposing agents such as air and water. Municipal waste landfills contain a large range of contaminants such as batteries, paint, oils, electrical products, and pharmaceuticals. Improper disposal of these materials provide one of the needs for a cap and cover system to remain totally effective and undamaged (Eggen et al., 2010). Under RCRA, the USEPA developed an approach to designing landfills for proper waste disposal as what is known as the "dry tomb" landfilling approach.

\subsubsection{Mining Applications}

In 1977, congress passed the Surface Mining Control and Reclamation Act that requires a mining company to demonstrate that a full reclamation can be completed before obtaining a mining permit (Henrich, 1994). When companies are unable to do the full reclamation, mining permits are forfeited and the land and waste remains idle. These sites along with sites left unreclaimed before 1977 are called abandoned mine lands (AML) and falls into the responsibility of the state governments. The Bureau of Land Management includes mine waste piles (e.g.. tailings piles, cyanide heaps, overburden piles, rock dumps) into AML (Ford and Walker, 2003). AML are evaluated by mine hazard index and reclamation method to prioritize sites for reclamation (Kubit et al., 2015).

When it is necessary for hazardous mine waste to be relocated, landfills or impoundments are designed as the dry tomb containment described in section 2.1.2. When waste relocation costs are too high, these materials are reclaimed through topographic reconstruction methods that involve regrading and recontouring (Kubit et al. 2015). Mine land reclamation should accomplish tasks of creating vegetation cover to develop into a functional ecosystem and be selfsustaining but from the perspective of environmental protection, prohibiting the release and 
mobilization of contaminants to water is most important (Pandey et al., 2005; Albright et al., 2010). In mine lands, contaminants are in the form of acid mine drainage, or AMD. Production of AMD occurs when resources rich in sulfide minerals, specifically iron sulfides, pyrite, and marcasite, are exposed to air and water during extraction, causing the materials to release sulfuric acid. The water and heavy metals then contaminate ground and surface water and can reach local streams and travel further into rivers, devastating plant and aquatic life (Jacobs et al. 2014).

Conventional reclamation includes topsoil placement above the mine refuse as a media to establish new vegetation. The soil cap can consist of a fine grained material to lower hydraulic conductivity or a more coarse grained soil for easier vegetation growth. Traditionally, vegetation has taken a component in stabilizing soils and preventing erosion, but has increasingly been used as a role in 'water balance cover' systems (Im, 2012).

\subsubsection{Conventional Waste Disposal}

Landfill cap covers are designed from a combination of a compacted clay liner, amended soil, geomembranes, geosynthetic clay liners, and polymer amended sand-bentonite barriers when geological barriers do not meet requirements (Rajesh et al., 2014). When the cover system is properly designed and installed, the material is separated from air and water and provides a more aesthetically pleasing solution to the excess waste material. The dry tomb approach is designed to completely isolate the filled material from water to prevent leachate from forming. Leachate is a highly contaminated landfill effluent and form when rain and part of the undesirable components of landfills pollute ground and surface waters (Ugurlu, 2004; Dajic, 2016). An effective cap cover should minimize the infiltration of rain water and mitigate the emission of green-gases gases carbon-dioxide and methane (Rajesh et al., 2014).

The dry tomb design consists of a composite impermeable layer surrounding the fill entirely. Landfill locations are usually chosen with a geologic structure with low permeability below the landfill to reduce contamination to ground water if leaching would occur. The first constructed layer of the composite liner is the low permeability soil liner. Clay is often the soil type chosen for its low hydraulic conductivity property that is once in place and compacted, will not allow water and contaminants to easily pass. The thickness and hydraulic conductivity of the impermeable layers are given requirements based on the type of waste to be disposed. Municipal waste requires a compacted soil layer of $2 \mathrm{ft}$ (Protection of Environment, 2012a). For hazardous solid waste, the soil component of the composite liner calls for at least $3 \mathrm{ft}$ of compacted soil 
material (Protection of Environment, 2012b). Plastic sheeting made of high density polyethylene is then placed inside of the clay layer. A high permeability drainage layer used as a leachate collection system is then constructed above the plastic liner and is the layer directly surrounding the waste. The leachate easily flows through the drainage layer to collection pipes to transport the leachate out of the landfill to a treatment facility (Lee and Jones-Lee, 2004).

The liner above the waste is constructed slightly differently. The top outermost layer is topsoil vegetated with native grass species. Landfills must have a cap of 18 in soil for an infiltration layer and a 6 in layer capable of plant growth (Protection of Environment, 2012a) Below the topsoil is a high permeability drainage layer with the plastic liner base to divert water that infiltrates the topsoil away from the waste (Lee and Jones-Lee, 2004). The design life of a properly constructed landfill is 30 years, at which point the waste is expected as no longer hazardous (Lee and Jones-Lee, 2004).

Earthen materials that make up layers of the composite cap and cover system are weak under tensile loading that can result from landfill settlement (Schanz, 2007). The heterogeneity of municipal solid waste can lead to differential settlement during decomposition from the reduction of thickness of the waste that produce cracking in the cap increasing hydraulic conductivity. As easily as water can infiltrate cracks in the liners, pollutants in the form of biogas emissions and leachates can escape. The addition of geomembranes and geosynthetic liners to the topsoil layer of the cap can reduce methane and carbon dioxide emissions compared to cracked natural liners (Rejesh et al., 2014).

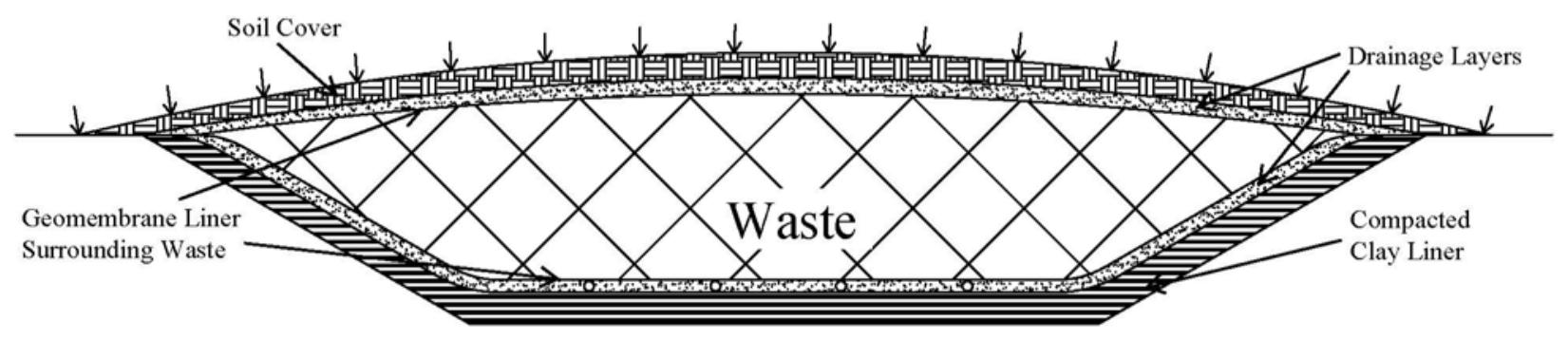

Figure 1. Conventional (dry tomb) cap and cover design

\subsubsection{Alternative Cover Systems}

Rather than eliminating water percolation into waste with the use of geomembranes and plastic liners, water balance cover systems use the vegetative cover and soil system to maintain a 
hydrologic balance withdrawing water from the underlying soil minimizing deep infiltration (Im, 2012). An attractive feature of the water balance covers are the cost savings accrued versus conventional (dry tomb) covers eliminating the purchase, hauling, and placement of the materials for the hydraulic barrier. Regulations in RCRA describe cover requirements attainable by certain design features of conventional covers, while the principles and materials employed in alternative covers require additional approval of final cover designs (Albright et al. 2010).

Water balance covers balance the water in and out of the system using two techniques. The first is water storage within the soil layer of the cap, and the second is water removal from the soil layer through evapotranspiration (Albright et al. 2010). For this, vegetation plays a larger role in alternative covers than conventional covers. In wet seasons, precipitation will require storage within the soil layer when the rate of evapotranspiration is slower than the rate of infiltration. The hydraulic conductivity of the soil layer is required to be low enough $\left(10^{-7} \mathrm{~cm} / \mathrm{s}\right)$ to keep water from passing entirely through the layer in the waste. When precipitation decreases and evapotranspiration increases, the stored water will exit through transpiration with the help of the capillary effect. Capillary rise occurs in fine grained soil when negative pore pressure causes an upward movement in water (Schanz, 2007). The thickness of the soil layer must be designed depending on the hydraulic conductivity and amount of precipitation to be stored, but should be kept at the minimum as increased thickness will lead to an increase in construction cost, and a decrease in rate of evapotranspiration from the increase in travel distance for the upward movement of water. Water balance covers are generally thicker than conventional covers which is associated with increased cost in replacement soil transportation, but reduce placement cost for placing uncompacted soil layers.

Another constraint to the alternative cover designs is a supplement that the USEPA published following the design guidelines of RCRA that state the permeability of the final cover cannot be greater than the permeability of the liner system or natural subsoils beneath the waste. This is to prevent any percolation that unintentionally reaches the waste from filling up the landfill when water cannot escape, creating the bathtub effect (Austin, 1992). 


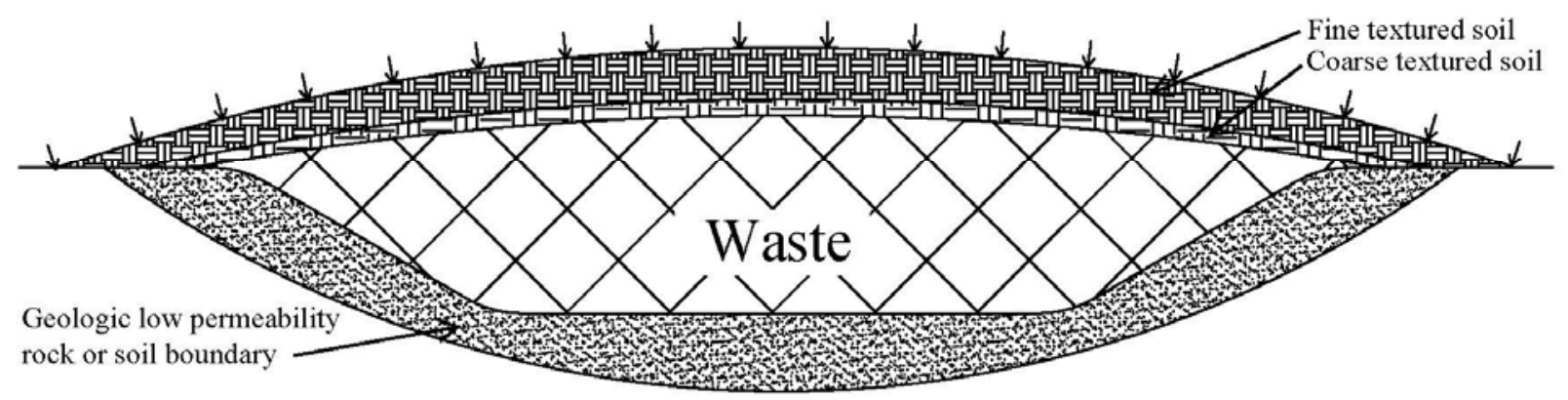

Figure 2. Alternative (water balance) cover design

\subsection{Hydraulic Barrier Design}

The idea of a hydraulic barrier as part of a cap and cover design in waste disposal is for the layer to impede the movement of water through to the waste. Hydraulic barriers can be constructed from compacted soil or geosynthetic material, or a combination thereof. It is common for the layer to have a saturated hydraulic conductivity less than or equal to $10^{-9} \mathrm{~m} / \mathrm{s}$. Challenges ensue from the long term sealing effect of the hydraulic barrier due to the differential settlements and subsidence associated with the body of waste (Rajesh and Viswanadham, 2011).

\subsubsection{Soil Barrier}

Soil mixtures can be of different types of soil: compacted clays, silts, sand and clay (bentonite) mixtures. Bentonite is a naturally occurring clay with high swelling capacity and low permeability due to over $75 \%$ percent of the material being made up of the clay mineral montmorillonite (Egloffstein, 2001). Bentonite content in most containment applications is between $5 \%$ and $15 \%$ of mixture (Gueddouda et al., 2016). When using these mixtures with bentonite as a barrier, it is important to maintain stability of the material when they come in contact with water and that the swelling potential of the material ensures contact with the under lying rock and that cracks existing or developing cracks will be self-filling. It is also good design practice for the mixtures to be a uniform grain size distribution to prevent bentonite leaching and decreasing the performance of the cap (Gueddouda et al., 2016).

\subsubsection{Geosynthetic Barrier}

The use of a classic soil cover prevents challenges after implementation when subsidence begins within the body of waste. Geosynthetics can play a couple of different roles in liners. Soil 
is weak in tension when differential settlement may occur (Schanz, 2007) so materials such as geogrid increase the shear strength of soil and reduce soil strain (Gilbert et al. 1996; Villard and Briancon, 2008; Rajesh and Viswanadham, 2011). Geogrid is a woven synthetic material used to increase the shear strength of soil. The geogrid is placed on top of and used in addition to the soil barrier and provides no decrease in hydraulic conductivity itself, but rather when it keeps cracks from forming in the soil barrier. Geomembranes are produced to be impervious linings. Geomembranes are also placed above the soil barrier and provide an impervious lining with hydraulic conductivity equivalence of $10^{-11} \mathrm{~m} / \mathrm{s}$ (Rowe and Brachman, 2004). Often, no strength increase is observed in the barrier when using a geomembrane, the two layers will act independent of each other (Rajesh and Viswanadham, 2011). Geomembranes are less effective at the liner seams, when it becomes wrinkled, and punctured, which are all inevitable (Rowe, 2005). Despite these small losses, the barriers are still effective and attractive for their relatively low cost to implement (Bouazza, 2002).

\subsection{Vegetation Establishment}

Revegetation is intended to encourage the development of mine soil, produce pleasing landscapes, and increase ecosystem productivity (Skousen, 2010). Vegetation is also important to decrease erosion and increase slope stability (Novotny, 2003) and is always part of the design in a cap and cover system for water balance covers and often conventional covers (Albright et al., 2010).

Many factors must be considered when choosing a revegetation strategy, including existing soil properties, site conditions, and the intended use after reclamation. Sites for vegetating may be of fresh topsoil that is rich in nutrients essential to plant growth, or may be a site regraded in mine spoil that does not provide the conditions needed for plant growth. Given the factors for a specific site, species selection, seeding rate, seeding application, and soil amendments used will vary. A large need for revegetation is at the completion of surface mining to comply with SMCRA's regulations. SMCRA requires the establishment of self-sustaining vegetation as part of the mine land reclamation (Henrich, 1994).

\subsubsection{Methods for establishing grass}

The best practice in establishing new vegetation is to first identify the site conditions and factors that will affect grass and plant growth. A particle size distribution should be performed on the soil to ensure soil media is not too coarse. Coarse textured soils have a very low water 
holding capacity, especially in the rooting zone (upper 24 in) (Daniels et al., 2010). Samples for nutrient analysis should be collected to check at a minimum for $\mathrm{pH}$ level, soluble salts, nitrogen, phosphorous, calcium, magnesium, and potassium (Skousen, 2010; Daniels and Zipper, 2010).

Plant species selection is an important part of both short and long-term establishment of cover. Grasses are generally chosen for cover (over forbs, shrubs, and trees) for the variety of grasses available for seeding, more readily available at reasonable costs, more tolerant of less than ideal conditions, and for large amounts of biomass in a short period of time (Skousen, 2010). Within that, certain grasses are more adapted to certain conditions than others.

A couple of examples for choosing species specific to site conditions can be seen in coal mining applications. In reclamation where mine spoil and overburden are used for topsoil, legumes are a common choice in revegetation seeding mixtures. This soil media is naturally low in nitrogen readily available to plants but essential to the growth of grasses. Legumes extract nitrogen from the air for their own use and store it in the soil which can also be beneficial to other plants and are part of the self-sustaining practices needed for mine land reclamation. Grasses other than legumes such as tall fescue, weeping lovegrass, and timothy are particularly tolerant of acidic soils and can be part of a seeding mixture for mine land reclamation (Skousen, 2010).

More than one species should be chosen for seeding to endure changes throughout seasons and life of the land. Not all species in a mixture are meant to remain long term. Nurse crops when seeded are intended to aid the target species which otherwise may fail to establish (Padilla and Pugnaire, 2006). Nurse crops or nurse plants are annual grasses which only come up when planted and will not naturally reoccur and grow quickly to provide protection to perennial species that are slower to establish, or will provide erosion control faster when necessary. When nurse plants die, the biomass provides a protective mulch and will decompose to return nutrients back to the soil. Common nurse crops are millets, annual ryegrass, oats, winter wheat and rye (Skousen, 2010).

Seed mixtures, mulching, and amendments are applied to soil by hand or by hydroseeding. Hydro-seeding is the placement of seeds, mulching, and fixing by mechanical spraying (Brofas and Varelides, 2000) that is used to cover large areas quickly and for use on steep slopes. It is the most common technique for seeding and improves likelihood of seed germination. Germination and establishment success is also increased with the time of year areas are seeded. 
In the Appalachian region, the best times of the year to seed are March - May and the end of August - October in normal climate conditions (Skousen, 2010). The hydro-seeding application rate can vary. Ranges are given per species, and the higher end of the ranges should be used on harsh sites with poor soil conditions (Skousen, 2010). Increasing the success of germination and plant growth can also be accomplished with the addition of lime and fertilizers.

\subsubsection{Soil Amendments}

Soil nutrient levels vary according to material composition and exposure to air, water, and surrounding biology, and will continue to change throughout the life of the material. When working with materials such a surface mine overburden and spoil for reclamation and revegetation in top-soil replacement, it is important to have the correct nutrients and $\mathrm{pH}$ level available for plant germination in the new soil. As vegetation grows and dies off, the soil nutrients are replenished. When land is disturbed and vegetation is stripped from the soil, it is likely that the soils will become unable to naturally regrow vegetation from the lack of organic matter and nitrogen being introduced back into the soil (Daniels and Zipper, 2010). When replanting, amendments such as lime and fertilizers will need to be added to the soil with the seeding mixture.

In conditions that $\mathrm{pH}$ levels fall below 5.5, reduced forage growth will be observed due to metal toxicities, phosphorus fixation, and reduced populations of nitrogen fixing bacteria. Lime is added to low $\mathrm{pH}$ soils at a rate of 1 to 5 tons per acre, depending on initial acidity, to reach a target $\mathrm{pH}$ of 6.5 for typical grassland forages (Daniels and Zipper, 2010).

Nitrogen is often deficient in soil containing little organic matter where nitrogen is stored. Legumes can be used to introduce nitrogen from the atmosphere into the soil and are a necessary component in a seeding mixture for reclamation success (Daniels and Zipper, 2010). In addition to planting legumes, nitrogen should be initially added to the soil through fertilization. At least 75 pounds per acre is needed to support annual and perennial grasses but should not exceed 150 pounds per acre to avoid suppressing the legume development when present (Daniels and Zipper, 2010).

In soils where minerals have been exposed to air and water for several years, soluble salts (phosphorus, potassium, calcium, and magnesium) are likely at levels toxic to new plants. When soluble salt levels are in the lower range (approaching 0) in soil tests, the soil is likely heavily weathered and depleted, and in need of added fertilizers. Phosphorus should be added at 110 
pounds per acre with potassium added at 55 pounds per acre for minimum plant and biomass production on new vegetation (Daniels and Zipper, 2010).

Organic matter is used for nitrogen storage and becomes more important as reclamations become self-sustaining. As more organic matter is added to the soil through biomass decay, more nitrogen is stored for plant take-up after fixation. Organic matter can be added during seeding in the form of saw dust, bark mulch, or biosolids (Daniels and Zipper, 2010). Biosolids are nutrientdense solid residuals generated from wastewater treatment that can create a cost effective disposal solution for fertilizer substitutes in agricultural and reclamation purposes (McFarland, 2001).

\subsubsection{Short Paper Fiber}

Short paper fiber (SPF or paper fiber) is a biosolid composed of the fibers of paper extracted from the treatment of wastewater produced by the process to make or recycle paper pulp (Laubenstein, 2004). The material is mostly solids of organic matter and microbial growth that contain some nutrients. The paper fiber has been tested as a soil amendment with abundant organic matter to improve soils, and for its clay content to create an impermeable cap on closed landfills (Camberato et al., 2006; Laubenstein, 2004; Daniels et al., 2013). If the paper fiber is not used in an application such as these, the material is transported to a landfill for disposal.

Daniels et al. (2013) evaluated the nutrients in SPF to determine the suitability of the paper fiber waste for use as a topsoil substitute, or for use as a soil amendment. The carbon to nitrogen ratio of the paper fiber is listed as 22.2:1 providing organic matter to the soil during decomposition. The testing determined that that just over $1 \%$ of the material is nitrogen available

for plant uptake, and would need to be supplied in heavy amounts to nitrogen deficient soils. The SPF was a basic material with a $\mathrm{pH}$ value of 8.1 and calcium carbonate equivalence (CCE) of $33.3 \%$ making a suitable material to neutralize the acidity of harsh soils. Another key beneficial value for the SPF is the phosphorous available at $79 \mathrm{ppm}$.

Daniels et al. (2013) also explored using the material as a soil amendment specifically in mine waste. With the extreme acidity and nutrient deficiencies of the low quality coal refuse left behind from surface mining, the soil does not alone provide an adequate growth media, as outlined in section 2.3. It is estimated that when using in mine spoil, 19\% of the total nitrogen applied in the mill sludge would be taken up as plant available nitrogen and therefore the amendment should be applied at a rate of 34 tons/acre in the first year of planting. If grass is able 
to grow, the cap and cover system of waste disposal can be implanted at a lesser cost when the SPF is easily available. 


\section{Methods}

A full-scale reclamation design was developed by Hopkinson et al. (2017) for the reclamation of a coarse coal refuse pile. The design includes features related to geomorphic landforming, geomorphic channel design, and cap design that have not yet been field tested. In this work, major features are evaluated in a pilot ( 0.28 acre) field test. The design of the field test plots went through several iterations, as described in the following sections, to meet the evaluation needs. Both constructability and performance are in consideration in this study.

\subsection{Study Site}

The site is an abandoned coarse coal refuse (CCR or refuse) pile in Greenbrier County, West Virginia, located near the town of Anjean. The site has been under control of WVDEP since 2001. The coal refuse pile spans more than 40 acres in total. There is a highwall along the eastern border where the last of the mining had occurred. An active coal mining operation not a part of this reclamation project is located north of the pile on the opposite side of the mountain.

The site remains unvegetated due to the harsh conditions of minimal quantity, low quality native soil and the large amount of coal refuse. It is unknown what is beneath the pile as far as containment, but with the amount of leaching from the pile, there is thought to be no linings beneath the refuse, only bedrock. Groundwater monitoring wells are also located throughout the site to monitor contamination beneath the pile. Large ditches capture the surface water and large seeps from the pile and divert it to a central on-site treatment location implemented by WVDEP (WVDEP, personal communication).

The treatment system onsite ensures pollutant levels are within permitted levels before discharging into the Meadow River. The treatment facility is an active treatment system utilizing chemicals to produce chemical reactions in which a precipitate will form and settle out of the solution in a series of 4 treatment ponds (Figure 3). A liquid solution of caustic soda $(\mathrm{NaOH})$ is added to the pollutants between ponds 1 and 2. As precipitation increases throughout the rainy seasons, the amount of caustic soda used in treatment can approach 1,000 gallons per day in large precipitation events. Treatment runs 365 days per year because of infiltration and the slow release of water out of the pile (WVDEP, personal communication). 


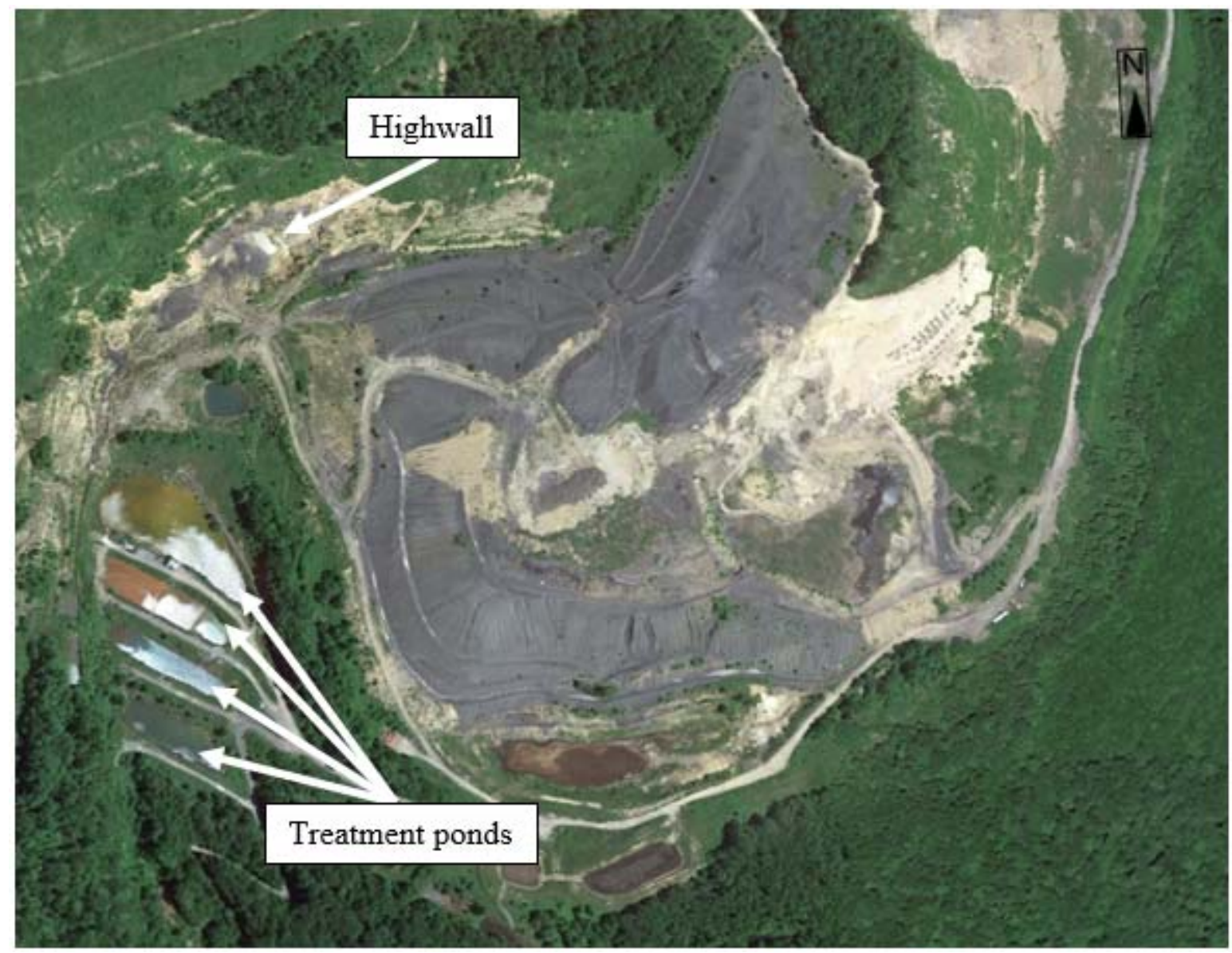

Figure 3. Royal Scot coarse coal refuse pile Greenbrier County, WV

\subsection{Features of full-scale design under evaluation}

The design of the small scale reclamation is based on the full scale geomorphic land design of the full reclamation completed by WVU (i.e., Lorimer, 2016; Hopkinson et al., 2017). The design implements surface reconstruction techniques to maximize long term material stability increasing surface water runoff and minimizing infiltration. The major design features are described briefly in the following paragraphs:

- Geomorphic landforming: The reclamation will consist of an entire site regrade using landforming principles. Final slopes are mainly $3 \mathrm{H}: 1 \mathrm{~V}\left(18.4^{\circ}\right)$. A small portion of 2H:1V $\left(25.6^{\circ}\right)$ slopes exist to maintain cut and fill balance.

- Geomorphic channels: Geomorphic channels were included to remove water from the surface into the existing sediment pond (Figure 3). 
- Cap: A cap is included to minimize infiltration into the pile. The cap is designed to incorporate the maximum use of onsite material in its hydraulic barrier and growth layer.

The cap is designed to incorporate the maximum use of onsite material in its hydraulic barrier and growth layer. The compacted layer will be a 1 to $2 \mathrm{ft}$ thick compacted low permeability layer implemented to lower the hydraulic conductivity of the refuse. On top of the hydraulic barrier will be the growth layer. The layer will be $1 \mathrm{ft}$ thick containing a mixture of refuse and short paper fiber. The blends being tested for use in the full reclamation are proportions of $60 \%$ CCR with $40 \%$ SPF (60/40 plot) and $80 \%$ CCR with $20 \%$ SPF (80/20 plot). This combination of refuse and SPF is intended to act as the base of a manufactured soil to support grass growth.

\subsection{Pilot test plots}

In the test plots, the two refuse/SPF (60/40 and 80/20) mixtures will be tested against a control plot of only refuse (refuse plot). Earlier versions of the test plot design included a varying thickness of the hydraulic barrier with the slope. The implemented plot designs include varying slopes but a constant barrier thickness. All other factors remained constant for testing including seed mixtures, mulching, weather and precipitation.

\subsubsection{Test Plot Location}

The location of the test plots are on the northern portion of pile, at an elevation of 3650 feet above mean sea level (Figure 4). The location is a relatively large, flat area with an abundance of refuse available for regrading to the final test plot design.

The project site has limited vehicle access set to be upgraded during plot construction to accompany the delivery of the paper fiber for the test plot construction and the eventual reclamation of the full site. 


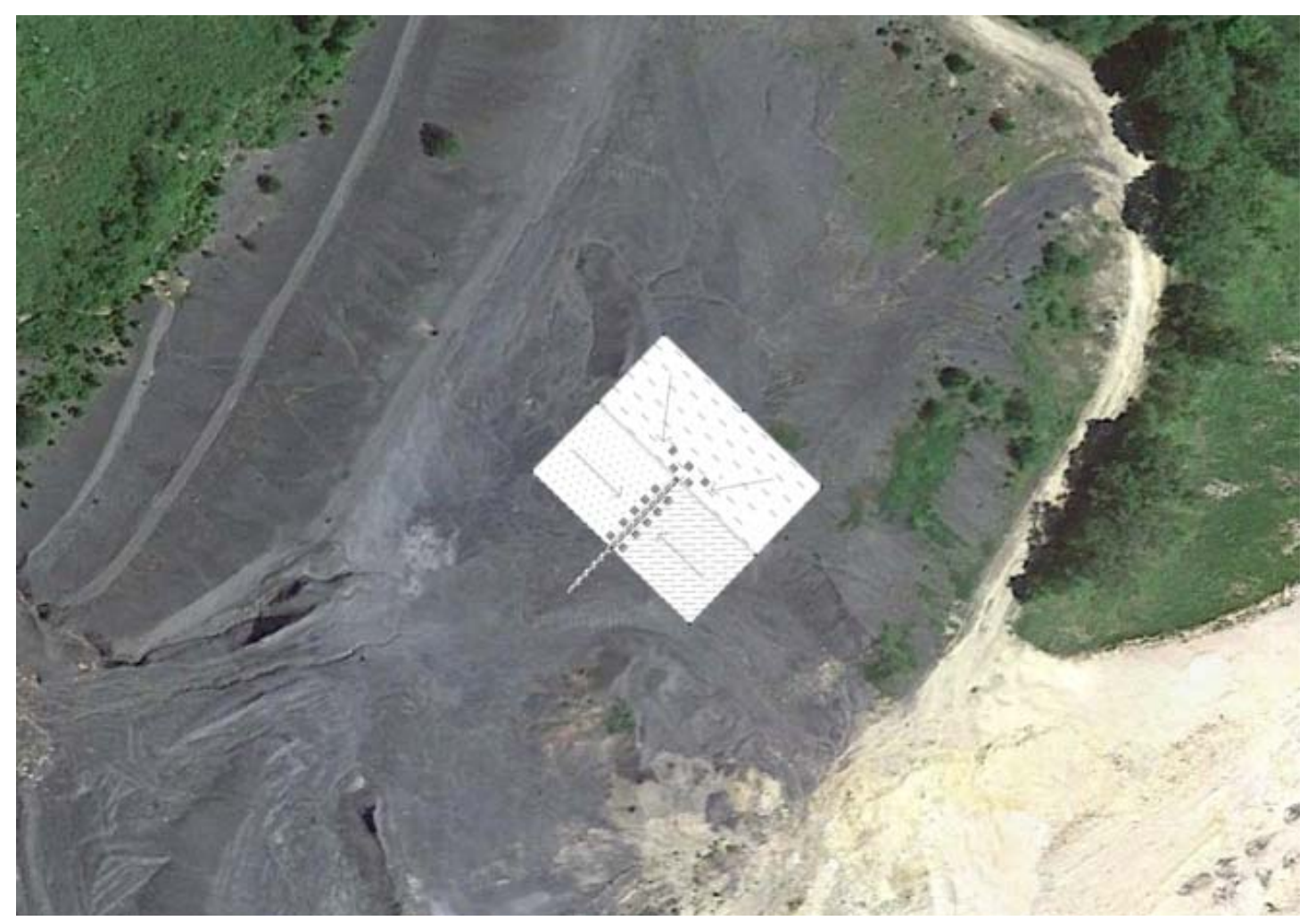

Figure 4. Test plot location on Royal Scot refuse site

The location proposed for the test plots are outlined in Figure 5. The rough location was decided by WVDEP, and final location was to be chosen based on minimum cut and fill volumes of the regrading. The area has an average slope of $10.8^{\circ}$ but this slope is misleading. As the survey results show in Figure 5, the area has two flat portions separated by a steep drop off (maximum slope $47.2^{\circ}$ ). The grade changes would prove beneficial to earthwork operations to construct part of the test plots on the higher elevation flat area and have the channel exit at the lower elevation flat for lower construction time and cost. 


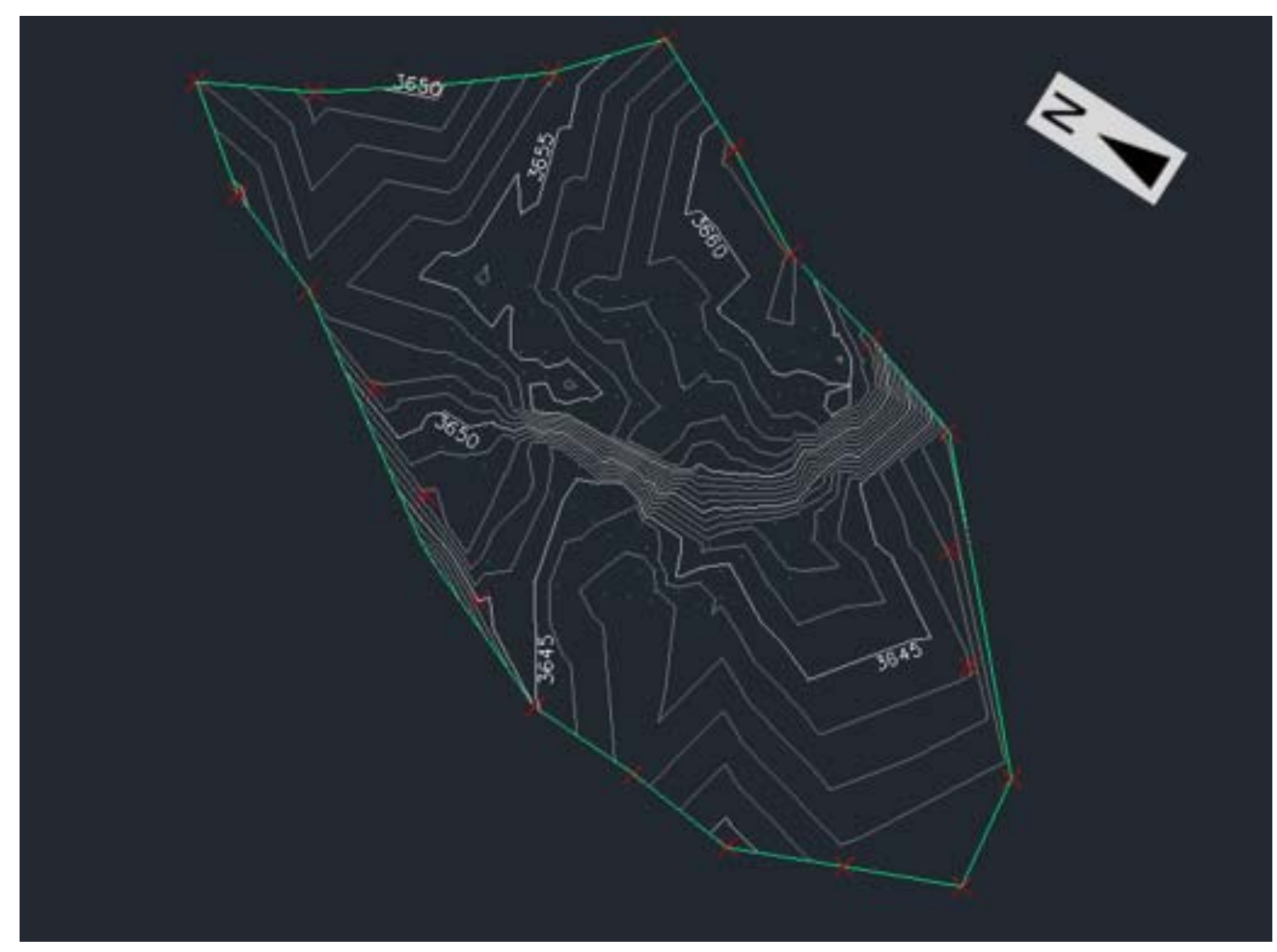

Figure 5. Existing topography of field site

\subsection{Test Plot Layout}

The test plot sizes were initially designed on maximum area and volume quantities set by the $350 \mathrm{yd}^{3}$ of paper fiber donated for the study: $300 \mathrm{yd}^{3}$ of paper fiber was to be used for test plots, and the remaining $50 \mathrm{yd}^{3}$ was to be used for field observation of degradation and material integrity during storage that may occur before placement. Plots were placed adjacent to each other to ensure the minimal inconsistencies that would alter results, but are also positioned that the differences in the growth layer mixing proportions would likely not have influence on another plot. Three versions were considered. The final design tests major design features and represents a small-scale geomorphic type watershed.

\subsubsection{Version 1}

Six individual plots would be placed next to one another with only enough space to allow a grade change from 3H:1V to 2H:1V (Figure 6). A diversion ditch would be placed upslope of the plots to avoid contamination of sediment moving into the plots during the study. The geomorphic channel downgrade of the plots would mimic that of the reclamation design by 
Lorimer (2016) to monitor performance of the channel, and to collect water leachate from the paper fiber for analysis.

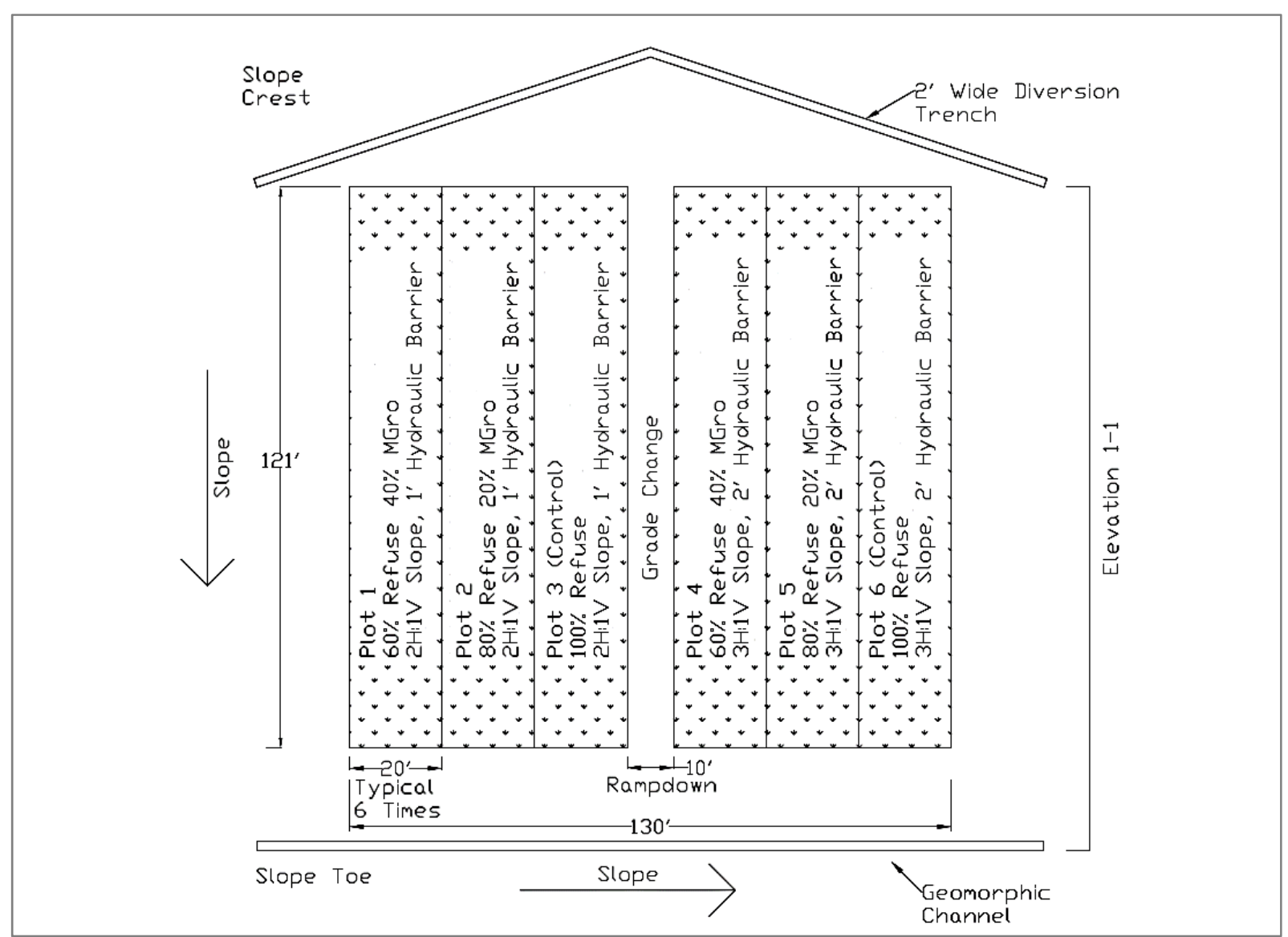

Figure 6. First version of Royal Scot test plot layout

The plots were to be placed on a portion of the site with a similar slope to those called for to minimize excavation and regrading. The optimum choice in location would mean no cut or fill material would be needed other than for mixing and placing the growth layer. For monitoring water runoff and erosion, the plots were to be much longer rather than wider. Based on a nominal width of $20 \mathrm{ft}$, the plots would be $121 \mathrm{ft}$ in length and use $163 \mathrm{yd}^{3}$ of paper fiber. Later designs would favor a more accurate representation of the reclamation, with the plots surrounding the channel on both sides. Total area of plot growth testing would be was 14,520 $\mathrm{ft}^{2}$. Version 1 required the least amount of earth movement to obtain final grade and construct the hydraulic barrier (Table 1). 
Table 1. Summary of layout variants

\begin{tabular}{|c|c|c|c|c|c|}
\hline Design & $\begin{array}{c}\text { Fill Volume } \\
\left(\mathrm{yd}^{3}\right)\end{array}$ & $\begin{array}{c}\text { Cut Volume } \\
\left(\mathrm{yd}^{3}\right)\end{array}$ & $\begin{array}{c}\text { Max. Fill } \\
\text { Height } \\
(\mathrm{ft})\end{array}$ & $\begin{array}{c}\text { Paper Fiber } \\
\text { Used } \\
\left(\mathrm{yd}^{3}\right)\end{array}$ & $\begin{array}{c}\text { Study } \\
\text { Surface Area } \\
\left(\mathrm{ft}^{2}\right)\end{array}$ \\
\hline Version 1 & 0 & 0 & 0 & 163 & 14,520 \\
\hline Version 2 & 3,844 & 10 & 38 & 300 & 32,640 \\
\hline Version 2.1 & 688 & 38 & 18 & 102 & 12,000 \\
\hline
\end{tabular}

\subsubsection{Version 2}

Version 2 (Figure 7) displayed a design layout with the plots completely surrounding and immediately bordering the channel. This version also utilized the $300 \mathrm{yd}^{3}$ of paper fiber available for the testing, setting the dimensions in Figure 7. The plots were then only testing a hydraulic barrier at $2 \mathrm{ft}$ compacted thickness and the slope at $3 \mathrm{H}: 1 \mathrm{~V}$. These parameters were chosen to represent the majority of the full-scale reclamation properties. Elevations of each plot corner were adjusted individually to maintain a constant slope. Total area for growth testing more than doubles that of version 1 at 32,640 $\mathrm{ft}^{2}$. Version 2 utilized the full quantity of paper fiber but most likely would have exceeded the budget of the test plot construction due to the cost of regrading a large amount of refuse material (Table 1). 


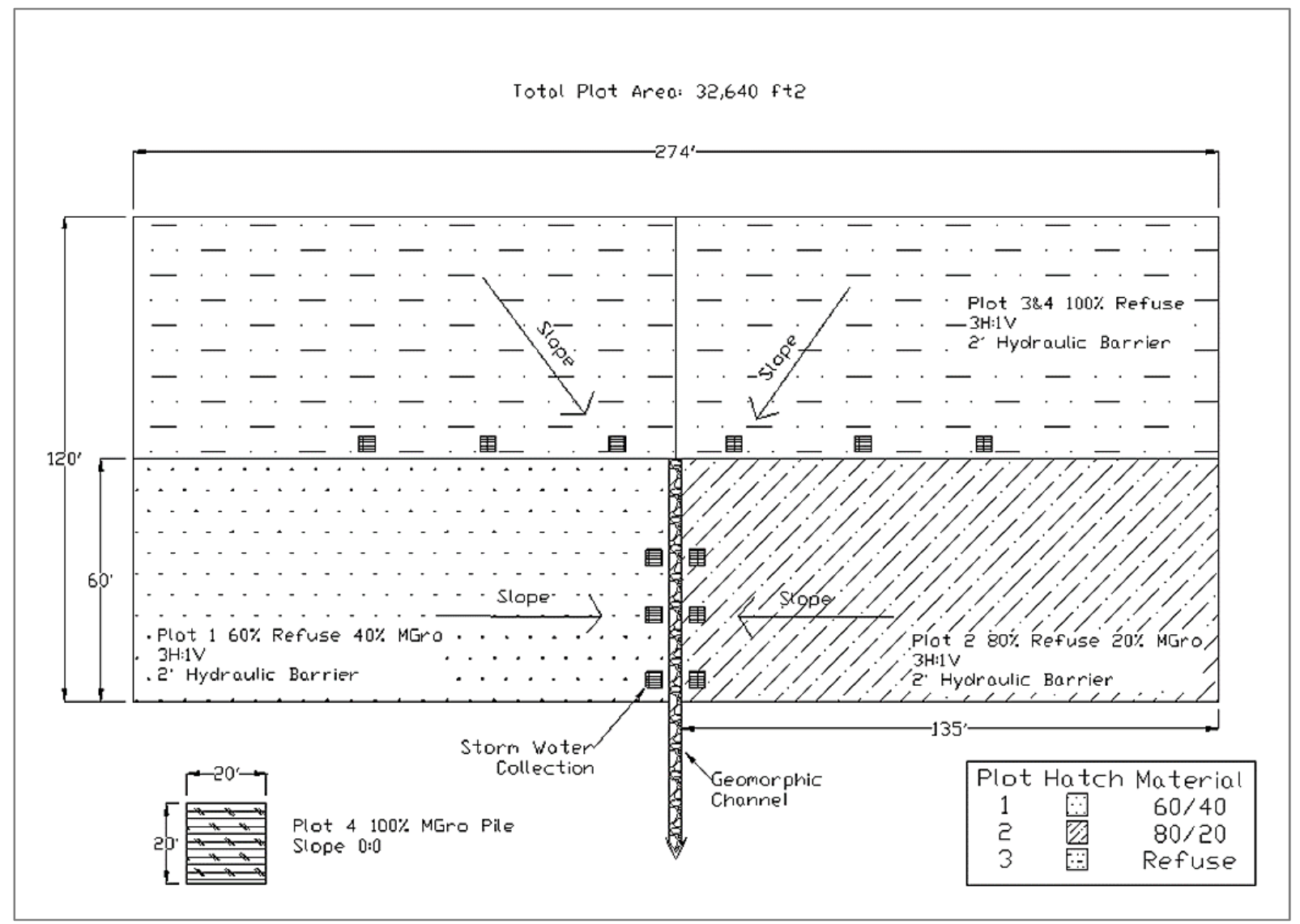

Figure 7. Second version of Royal Scot test plot layout

\subsubsection{Version 2.1}

This version (Figure 8) only contains a few variations from the previous version and is that chosen for the final design. The plots border the channel and test the same proportions of paper fiber and refuse. For ease of construction, final elevations of each corner plot would be constant. With that comes a varying slope angle with the length of each slope. Slope of the surface varies from $12.1^{\circ}$ to $24.4^{\circ}$, which gives the opportunity to study surface stability on a wide range of gradations. In the reduced study area of $12,000 \mathrm{ft}^{2}$, paper fiber use will be less at $102 \mathrm{yd}^{3}$.

Another limiting factor of the size and placement of the plots other than the amount of paper fiber available and useable land is the construction budget. With the smaller plots and overall footprint, version 2 required more than five times more fill volume than version 2.1. Dimensions were decreased from version 2 for a smaller study surface area and fill volume resulting in less overall construction costs for the design of version 2.1 (Table 1). 


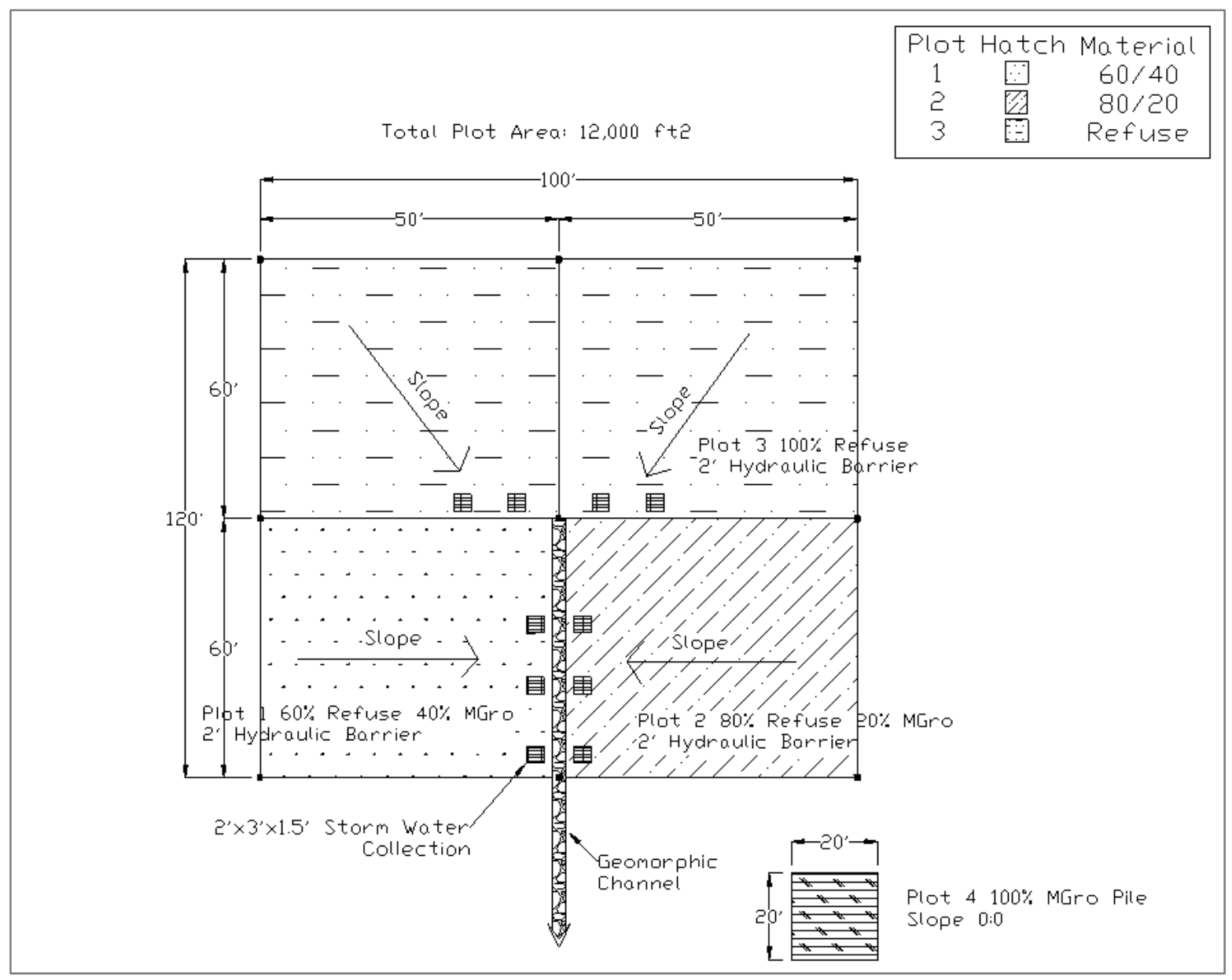

Figure 8. Test plot layout design chosen for Royal Scot reclamation

\subsection{Construction Design}

A series of tasks were completed over several weeks in order to complete all portions of the test plots study. Construction began with earthwork shaping and channel construction, followed by the hydraulic barrier and growth layer placement. The test plots were then completed with seeding and mulching.

\subsubsection{Regrading}

The existing topography survey data was analyzed using AutoCAD Civil 3D. The first surface was created as existing ground. From there, the proposed surface was created in reference to the original ground. The point of no elevation change was set at the exit point of the channel. With plot dimensions at $50 \mathrm{ft}$ long and $60 \mathrm{ft}$ wide for the $80 / 20$ and $60 / 40$ plots, new elevations were calculated at the top of the channel, directly upslope and perpendicular, to be regraded and filled to a slope of $3 \mathrm{H}: 1 \mathrm{~V}$. All of the outer corners away from the channel were set 
at the same elevation, $3665.49 \mathrm{ft}$. This gave reduced slopes on the eastern side of the refuse plot (plot 3, Figure 8), and a steeper slope on the western side of the SPF plots (plots 1 and 2, Figure 8). The points could were then joined in a TIN surface (Figure 9).

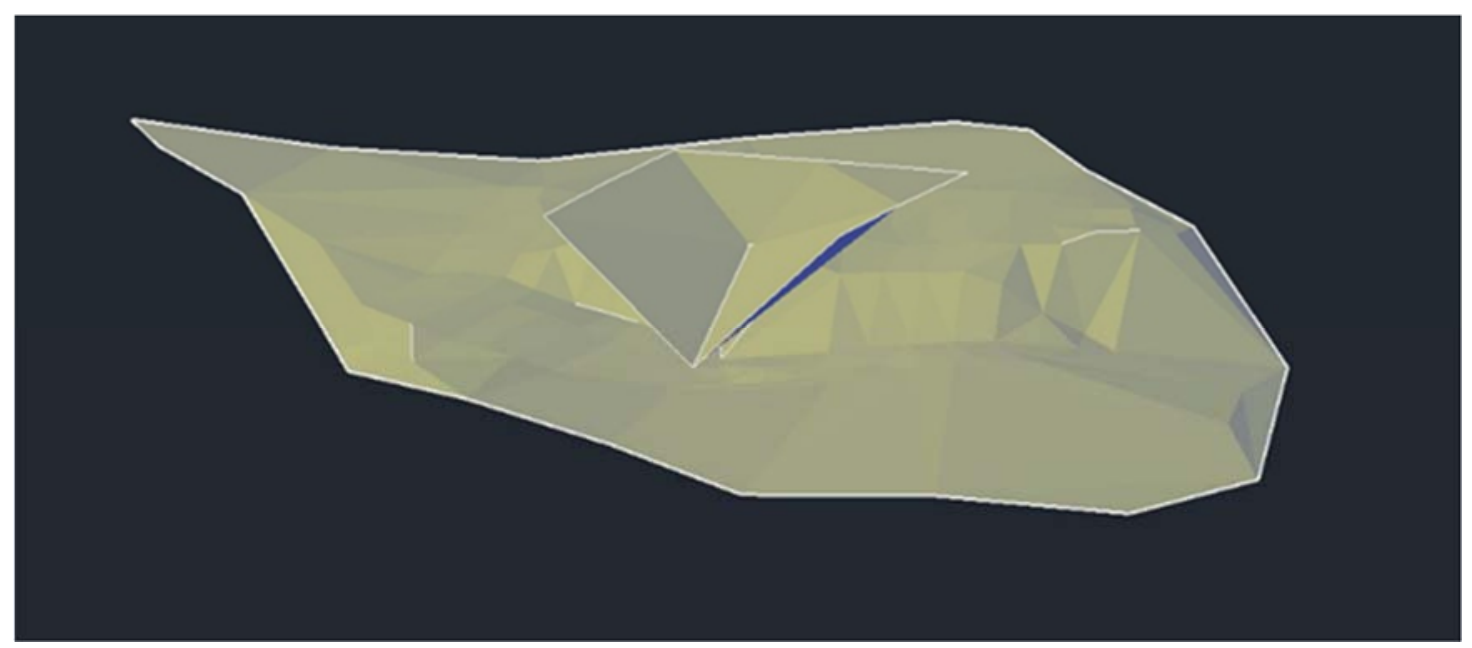

Figure 9. Conceptual 3D layout of proposed test plot surface (no vertical exaggeration)

Volume was calculated as earthwork quantities needed to construct the surface in the field. As Table 1 shows, net fill volume for construction was $650 \mathrm{yd}^{3}$. The area cut and fill map is shown in Figure 10. The outer boundaries required the most fill volume. The areas of cut were around the start of the channel, to slope the surfaces into the channel for collection. 


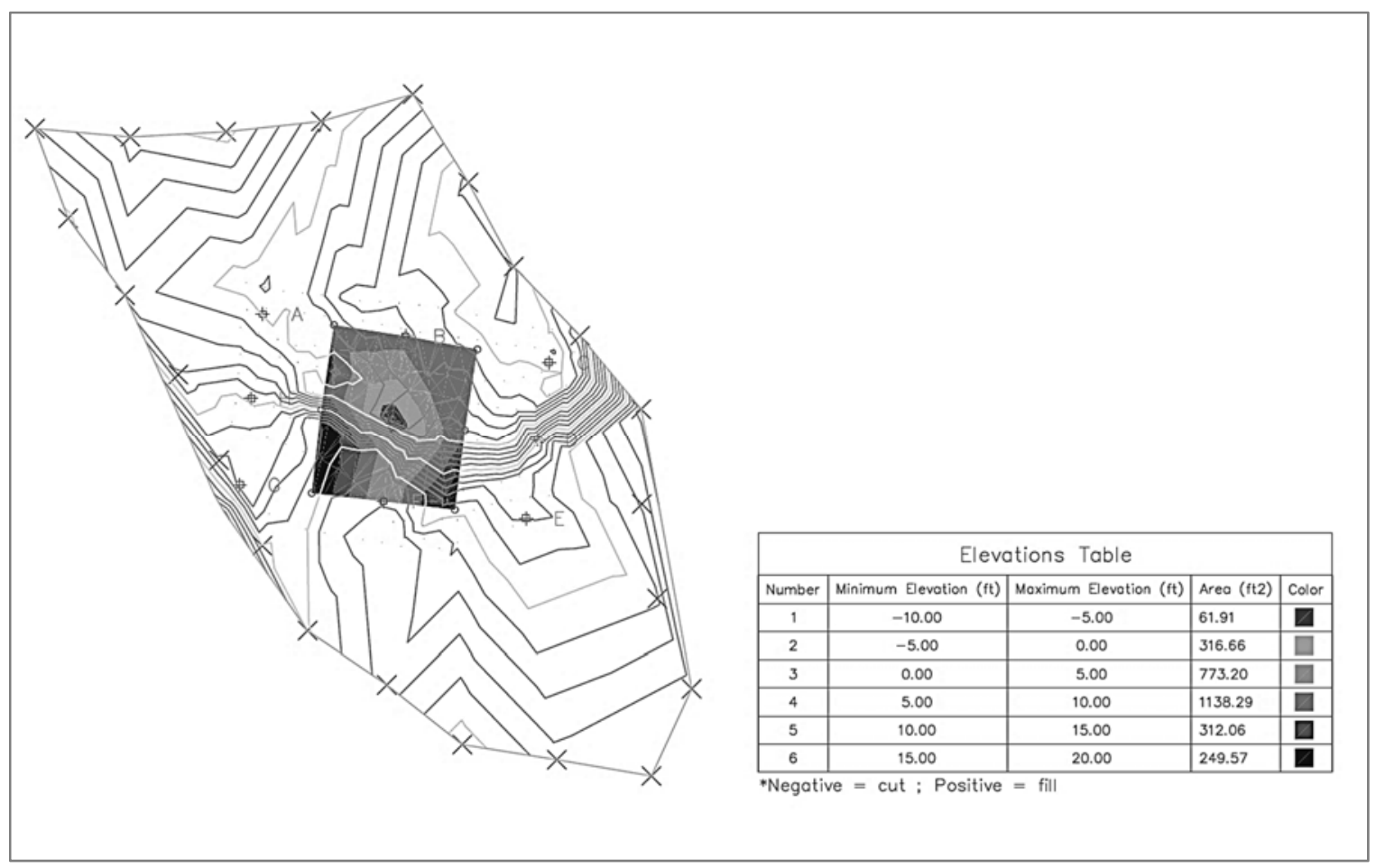

Figure 10. Cut and fill map for proposed test plots

\subsubsection{Channel Characteristics}

The channel implemented in the test plot design is that of the final design completed by Lorimer (2016) (Figure 11). The length is equal to the width of plots 1 and 2, at $60 \mathrm{ft}$. Facing upslope, the $60 / 40$ blend plot runoff will enter from the left, and 80/20 plot from the right. The refuse plot runoff will enter at the beginning of the channel. The slope is a constant $10 \%$, classifying it as a steep channel. The bottom and top widths of the channel are $4 \mathrm{ft}$ and $6.5 \mathrm{ft}$, respectively. The channel is to be lined with sandstone gravel with $\mathrm{D}_{50}$ equal to $9 \mathrm{in}$. The hydraulic barrier is $2 \mathrm{ft}$ of compacted refuse beneath the filter layer and riprap liner. Channel characteristics were designed in SedCad based on the 10\% slope of the channel. 


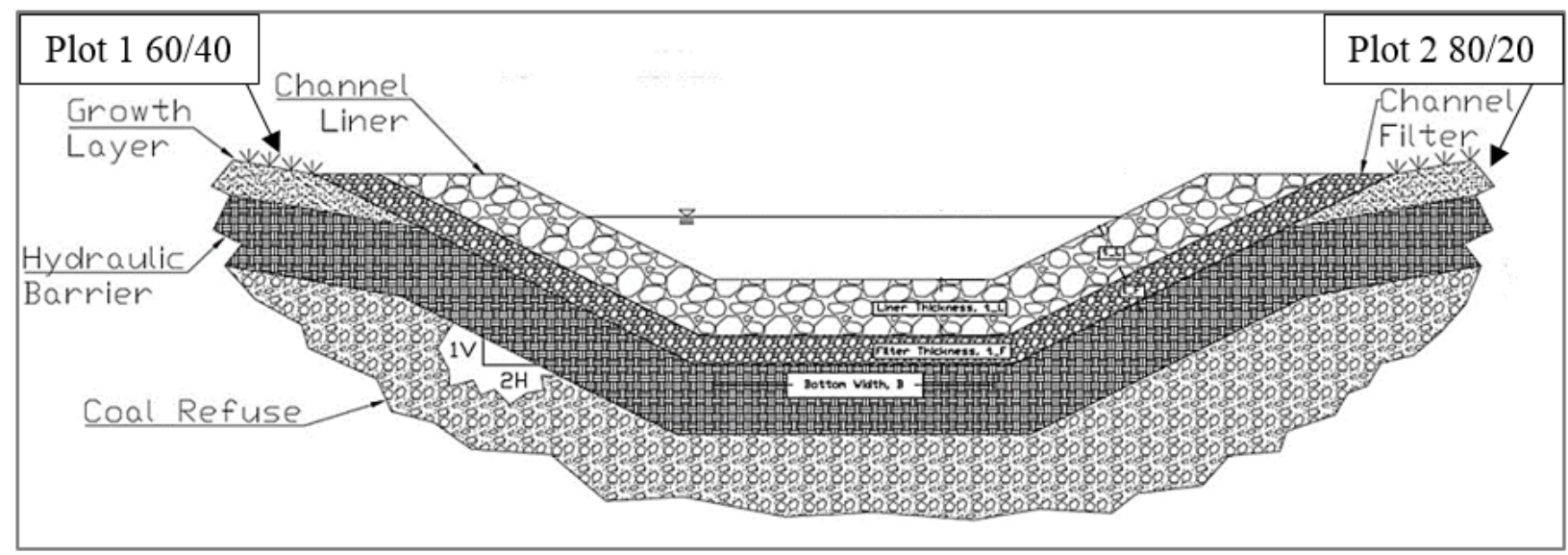

Figure 11. Geomorphic channel design (adapted from Hopkinson et al., 2017)

Table 2. Channel dimensions

\begin{tabular}{|l|l|}
\hline \multicolumn{2}{|c|}{ Channel dimensions } \\
\hline Depth (ft) (with freeboard) & 0.65 \\
\hline Bottom width (ft) & 4 \\
\hline Top width (ft) & 6.5 \\
\hline D $_{50}$ (in) & 9 \\
\hline Filter $\mathrm{D}_{50}$ (in) & 3 \\
\hline
\end{tabular}

\subsubsection{Hydraulic Barrier}

The hydrauluic barrier is design as the low permeability barrier between the growth layer and the in-situ refuse (Figure 12). The layer thickness is $2 \mathrm{ft}$ after compaction. 


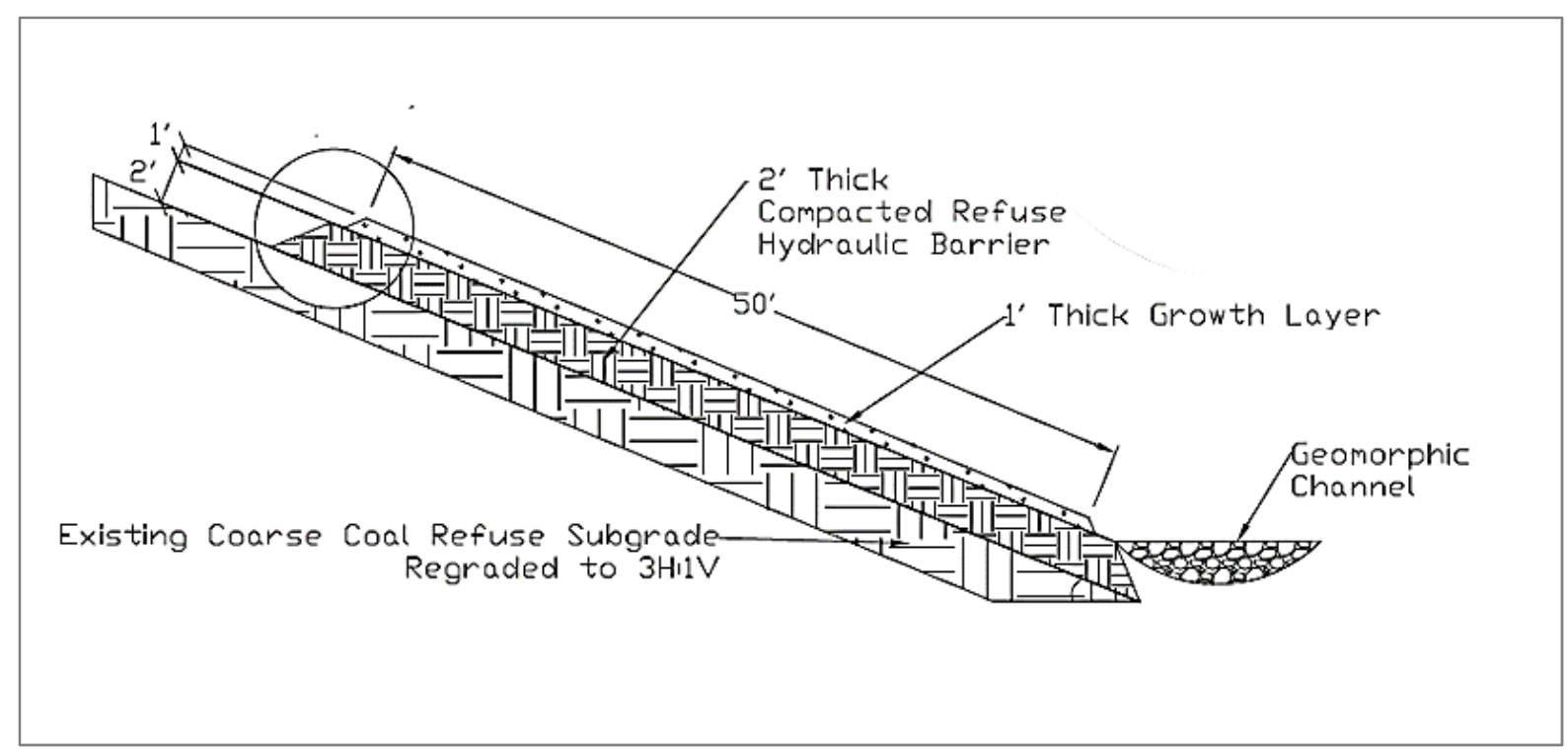

Figure 12. Cross sectional view of layout with hydraulic barrier

According to Stevens (2016), the maximum dry density of the refuse compacted at 100\% standard Proctor energy is 100.7 pcf and an optimum moisture content of $14.2 \%$. To receive the low hydraulic conductivity required for the design, 95\% of max dry density (95.7 pcf) needs to be achieved during placement, along with a moisture content within $2 \%$ of optimum $(12.2 \%$ $16.2 \%)$.

\subsubsection{Growth Layer Placement}

The growth layer is the outermost portion of the cap design. The layer consists of a blend of SPF and coal refuse in two areas with different proportions. Plot 1 will have $60 \%$ refuse with $40 \%$ SPF and plot 2 will have $80 \%$ refuse with 20\% SPF. Materials are to be mixed thoroughly before placing on top of the hydraulic barrier. Based on the area of each plot and the blends specific to each, growth layers can be mixed with excavator buckets to ensure correct quantities. Table 3 gives placement quantities for each plot based on standard bucket sizes, which can vary based on equipment choice. 
Table 3. Quantities for mixture based on equipment bucket sizes

\begin{tabular}{|c|c|c|c|c|c|c|c|c|}
\hline \multicolumn{2}{|c|}{} & Bucket Width (in): & \multicolumn{2}{c|}{36} & \multicolumn{2}{c|}{42} & \multicolumn{2}{c|}{48} \\
\cline { 3 - 9 } & Capacity (yd $\left.\mathbf{( y y}^{3}\right)$ & \multicolumn{2}{c|}{0.68} & \multicolumn{2}{c|}{0.82} & \multicolumn{2}{c|}{0.97} \\
\hline $\begin{array}{c}\text { Plot } \\
\text { Number }\end{array}$ & $\begin{array}{c}\text { Growth } \\
\text { Layer }\end{array}$ & $\begin{array}{c}\text { Mixture Ratio } \\
\text { Refuse:SPF }\end{array}$ & \multicolumn{2}{|c|}{ Buckets / Plot } & \multicolumn{2}{c|}{ Buckets / Plot } & \multicolumn{2}{c|}{ Buckets / Plot } \\
\cline { 4 - 9 } & Refuse & SPF & Refuse & SPF & Refuse & SPF \\
\hline 1 & $\begin{array}{c}60 \% \text { Refuse } \\
40 \% \text { SPF }\end{array}$ & $3: 2$ & 163 & 109 & 135 & 90 & 115 & 77 \\
\hline 2 & $\begin{array}{c}80 \% \text { Refuse } \\
20 \% \text { SPF }\end{array}$ & $4: 1$ & 163 & 41 & 135 & 34 & 115 & 29 \\
\hline 3 & $100 \%$ Refuse & $1: 0$ & 327 & 0 & 271 & 0 & 229 & 0 \\
\hline
\end{tabular}

\subsubsection{Seeding and Mulching}

Shortly after placement of both of growth layers, the site is to be seeded according to WVDEP specifications and scheduling of permanent seeding (3.11) (WVDEP, 2006). Seeding should occur in spring (March - May) or fall (August - October). The mixture was composed of six grass varieties added at different application rates. Orchardgrass (dactylis glomerata) at 15 lb/acre, birdsfoot trefoil (lotus corniculatus) $15 \mathrm{lb} / \mathrm{acre}$, red clover (trifolium pretense) $10 \mathrm{lb} / \mathrm{acre}$, annual ryegrass (lolium multiflorum) $15 \mathrm{lb} / \mathrm{acre}$, bicolor lespedeza (lotus corniculatus) $1 \mathrm{lb} / \mathrm{acre}$, and either foxtail millet (setaria italica) $12 \mathrm{lb} /$ acre or winter wheat (tritcum aestivum) at 20 lb/acre. Specifications also require the use of only plants from certified "blue tag" seeds. Seed and mulch will be combined and then applied on test plots via hydroseeding method (Table 4).

Table 4. Seed selection and application rate

\begin{tabular}{|c|c|}
\hline Variety of Seed & Application Rate (lb/acre) \\
\hline Orchardgrass & 15 \\
\hline Birdsfoot Trefoil & 15 \\
\hline Red Clover & 15 \\
\hline Annual Ryegrass & 1 \\
\hline Bicolor Lespedeza & 12 or 20 \\
\hline Foxtail Millet or Winter Wheat & \\
\hline
\end{tabular}




\subsection{Data Collection}

After completion of the test plot construction, performance of the test plots were monitored through vegetation ground cover, infiltration, post construction surveying, erosion observations, surface water runoff quality, and surface temperature.

\subsubsection{Vegetation}

Ground cover vegetation was measured each month throughout the growing season. Five points are selected on each plot for measurement. The five points on each plot are upper left, upper right, middle, lower left, and lower right. Exact locations are not marked for measurements to help get a wider range of area monitored throughout the length of the data collection.

Ground cover was measured using a grid placed above the vegetation (Calloudon et al.,1996; Elzinga et al., 1998). The grid has 100 intersections, which marks specific areas on the ground surface (Figure 13). A second grid which is a copy of the first, is below the first to ensure a true perpendicular view to improve accuracy (Figure 13). If live vegetation is present directly under the intersection, the area is counted for $1 \%$ cover of the sample. The mean of the five sample locations will recorded for the ground cover of each plot.

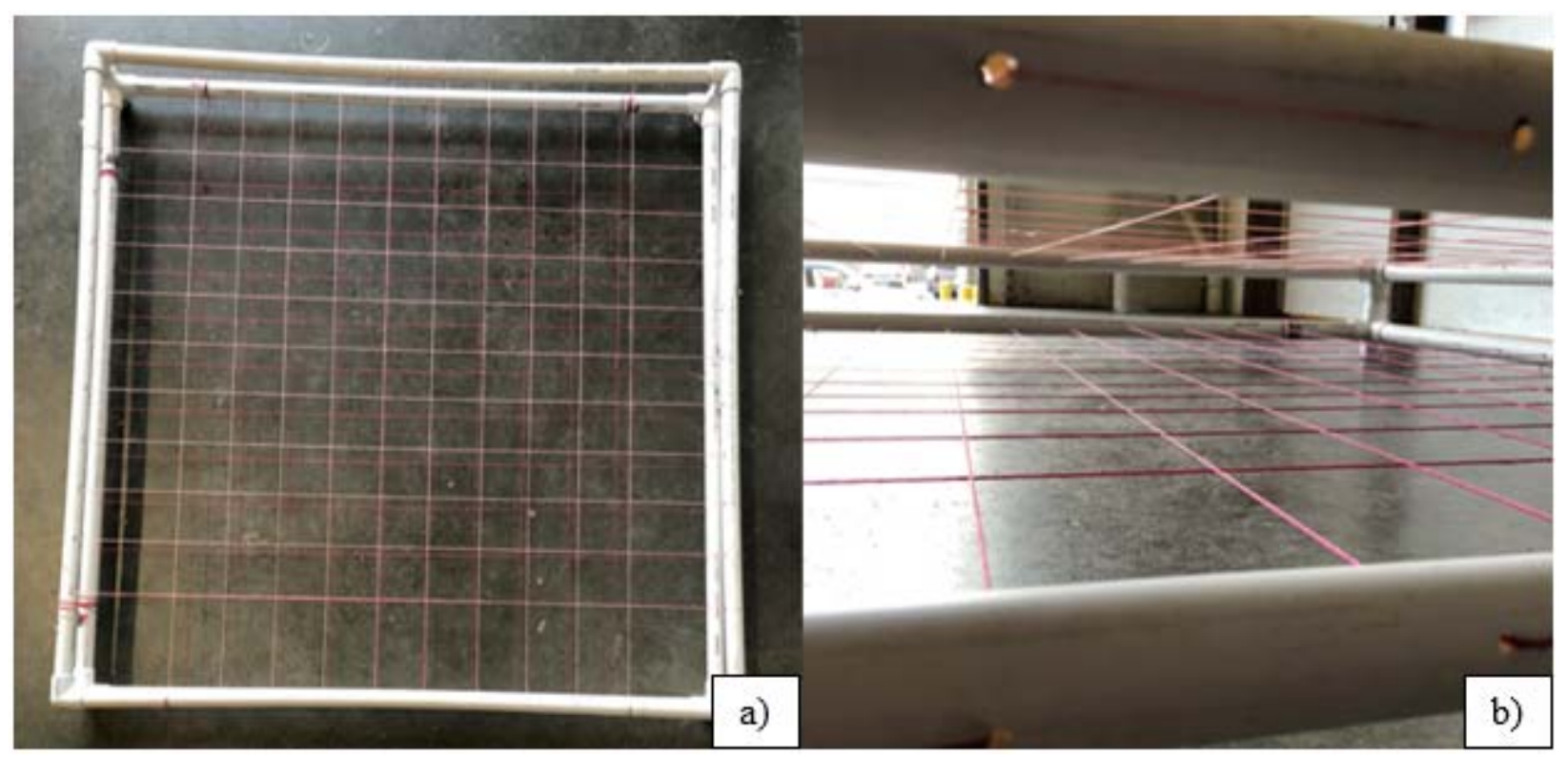

Figure 13. a) device for measuring vegetation ground cover b) double grid design on ground cover measuring tool 


\subsubsection{Infiltration}

Infiltration of both the hydraulic barrier and growth layer were measured. Saturated hydraulic conductivity will be measured through several infiltration measurements until results become steady. Hydraulic conductivity will be measured as the site exists before regrading, upon completion, and periodically through site monitoring.

Infiltration was measured with Turf-Tec International 6-inch infiltrometer (Figure 14) following standard methods.

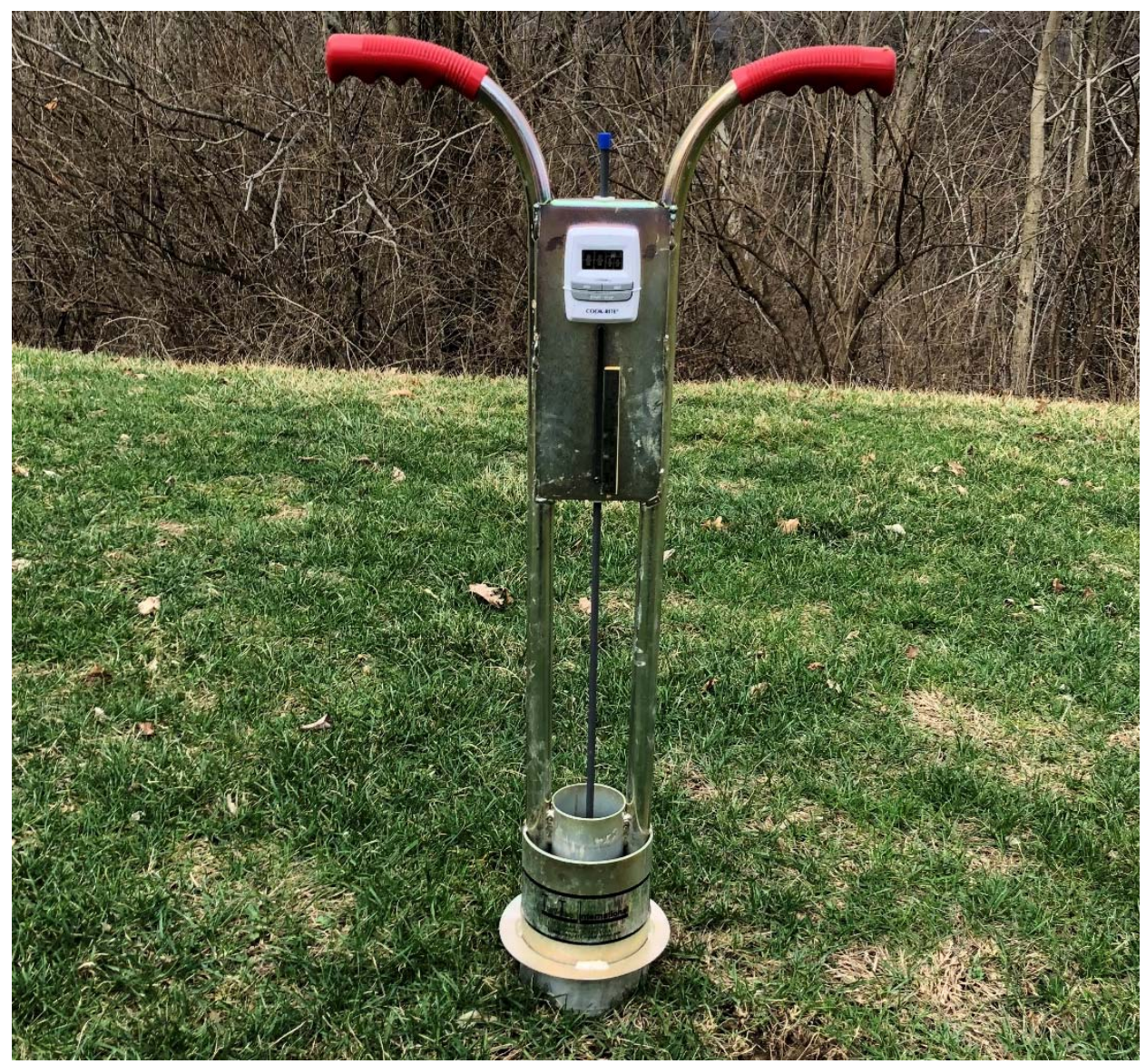

Figure 14. Infiltrometer for determining infiltration rates of soil media

\subsubsection{Surface Runoff Water Quality}

Water runoff from the cap will be monitored on each plot, before reaching the channel.

Fifteen collectors were placed throughout the test plots (five on each plot). They were constructed from 6-in diameter PVC pipe cut to 8 in and capped on the bottom (Figure 16). The top end was left open allowing water to flow from the surface for storage of 0.98 gal of water in 
each. A hook is added to the end of the design that will be attached to a rod driven into the ground below the collector approximately $12 \mathrm{in}$. This helped to minimize vertical displacement when pore pressure exerts an upward force that may cause the top to move above ground level, which would make them ineffective. A screen was added to the open end of the collectors to filter larger solid particles out of the sample (Figure 18). The screen is $9 \times 9$ mesh with an apparent opening size (AOS) of 0.10 in.

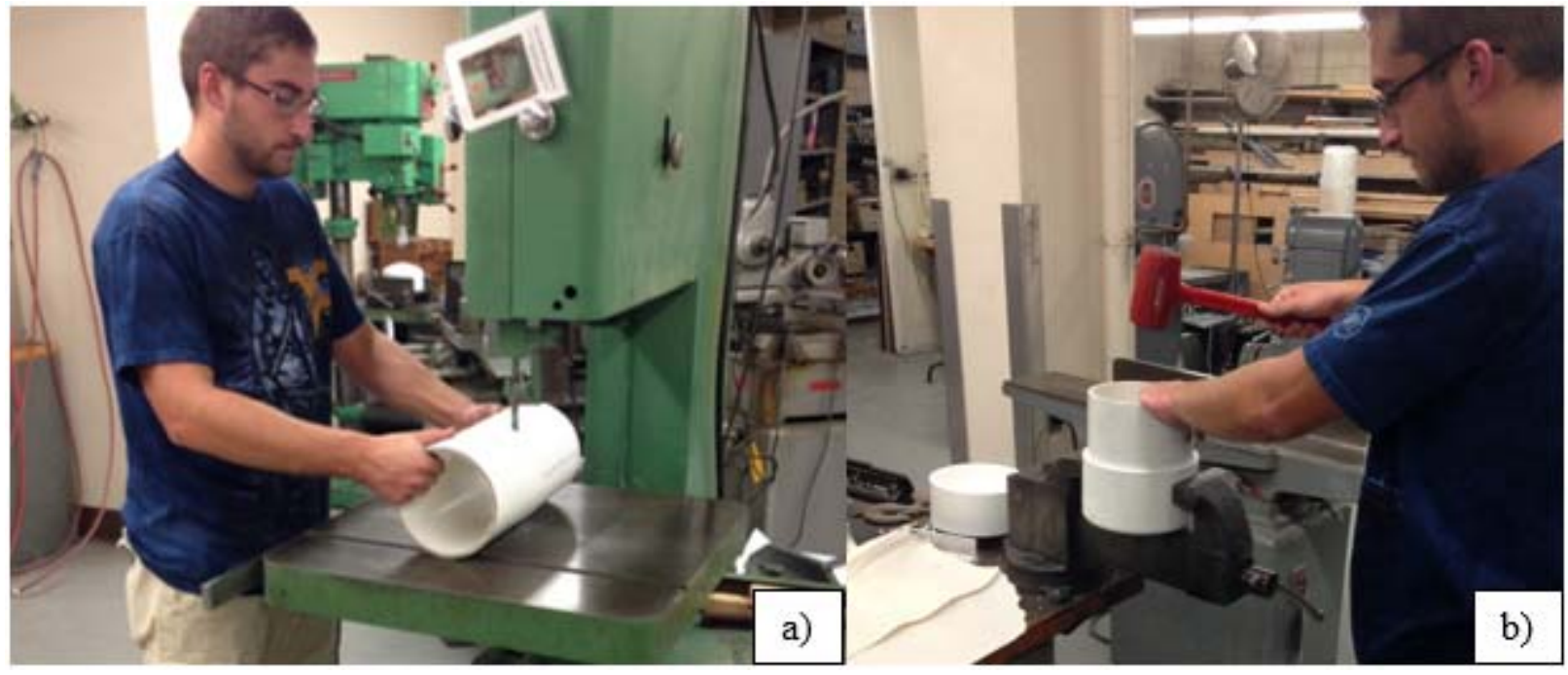

Figure 15. a) Constructing surface runoff collector b) Assembling runoff collector

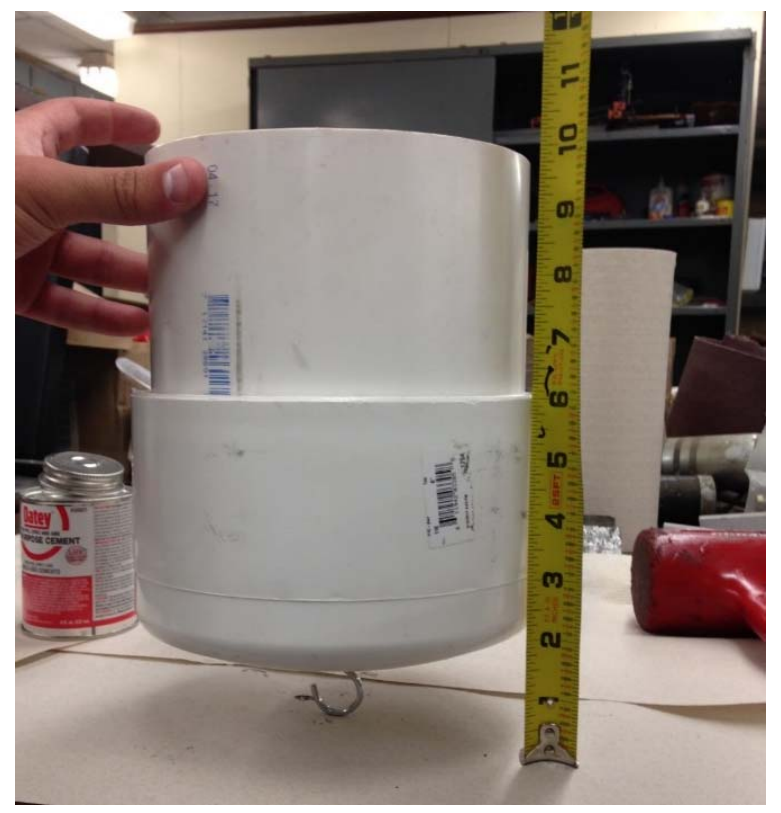

Figure 16. Completed construction of surface runoff collector 


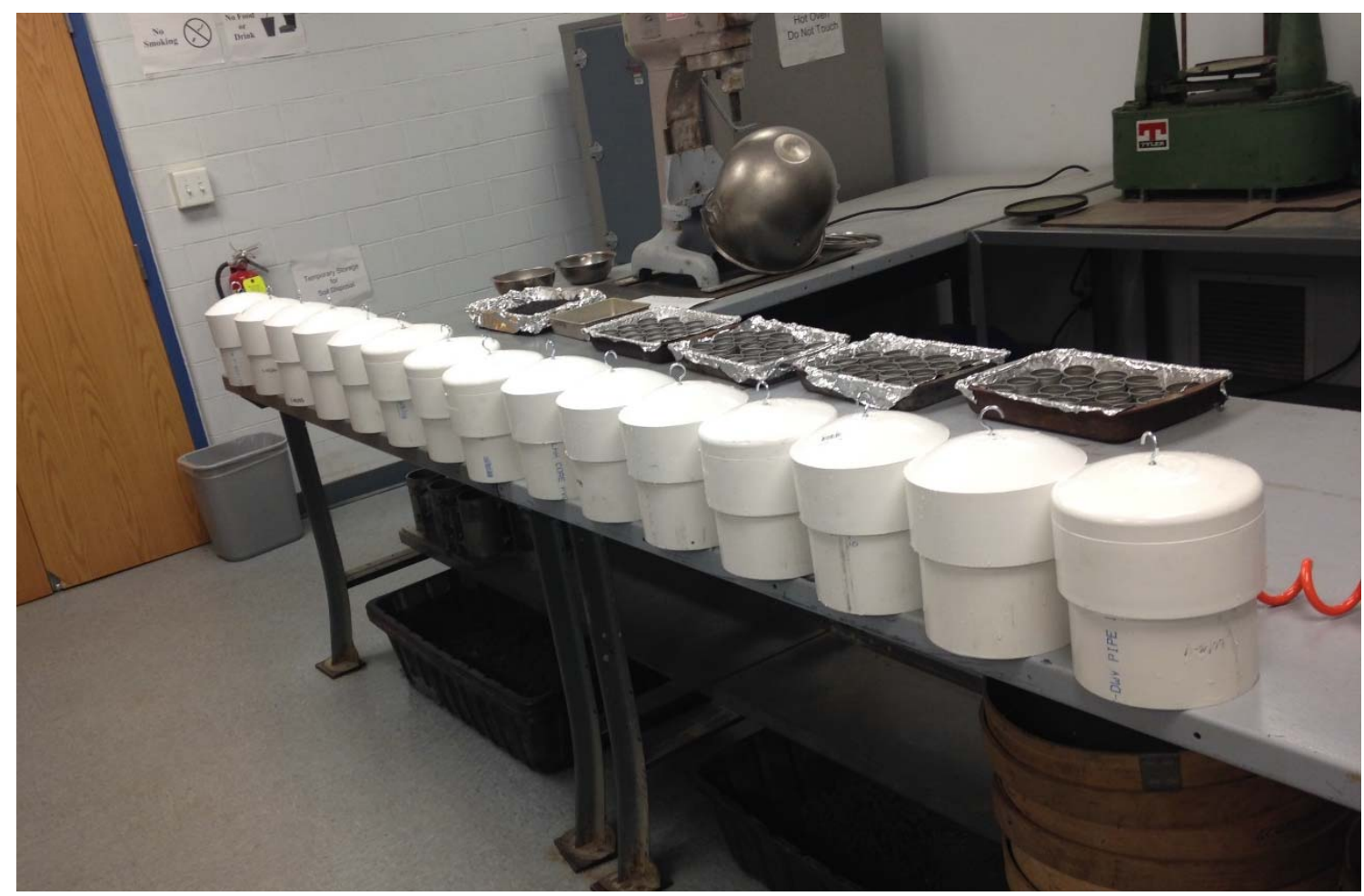

Figure 17. 15 surface runoff collectors for field application

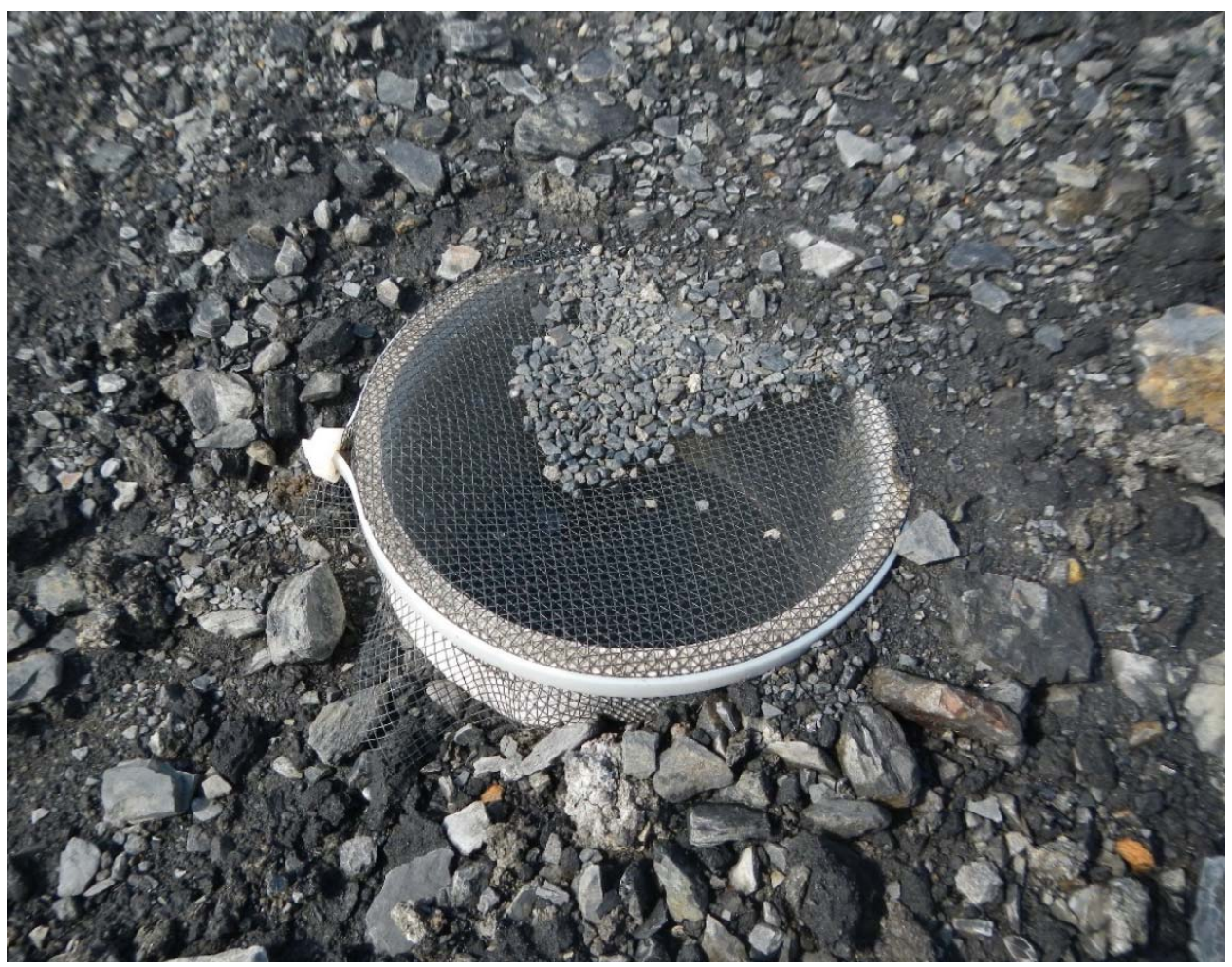

Figure 18. Screen added to runoff collectors for large particle filtration 


\subsubsection{Surface Temperature}

Temperatures were collected with a General ${ }^{\circledR}$ IRT207 infrared thermometer (Figure 19). Surface temperature was introduced to monitor difference in surface temperatures of each of the plots. With different aspect of the two growth plots, it needed to be determined if this would possibly have an influence on vegetation growth. In addition, the dark nature of the growth media may retain higher temperatures, affecting germination.

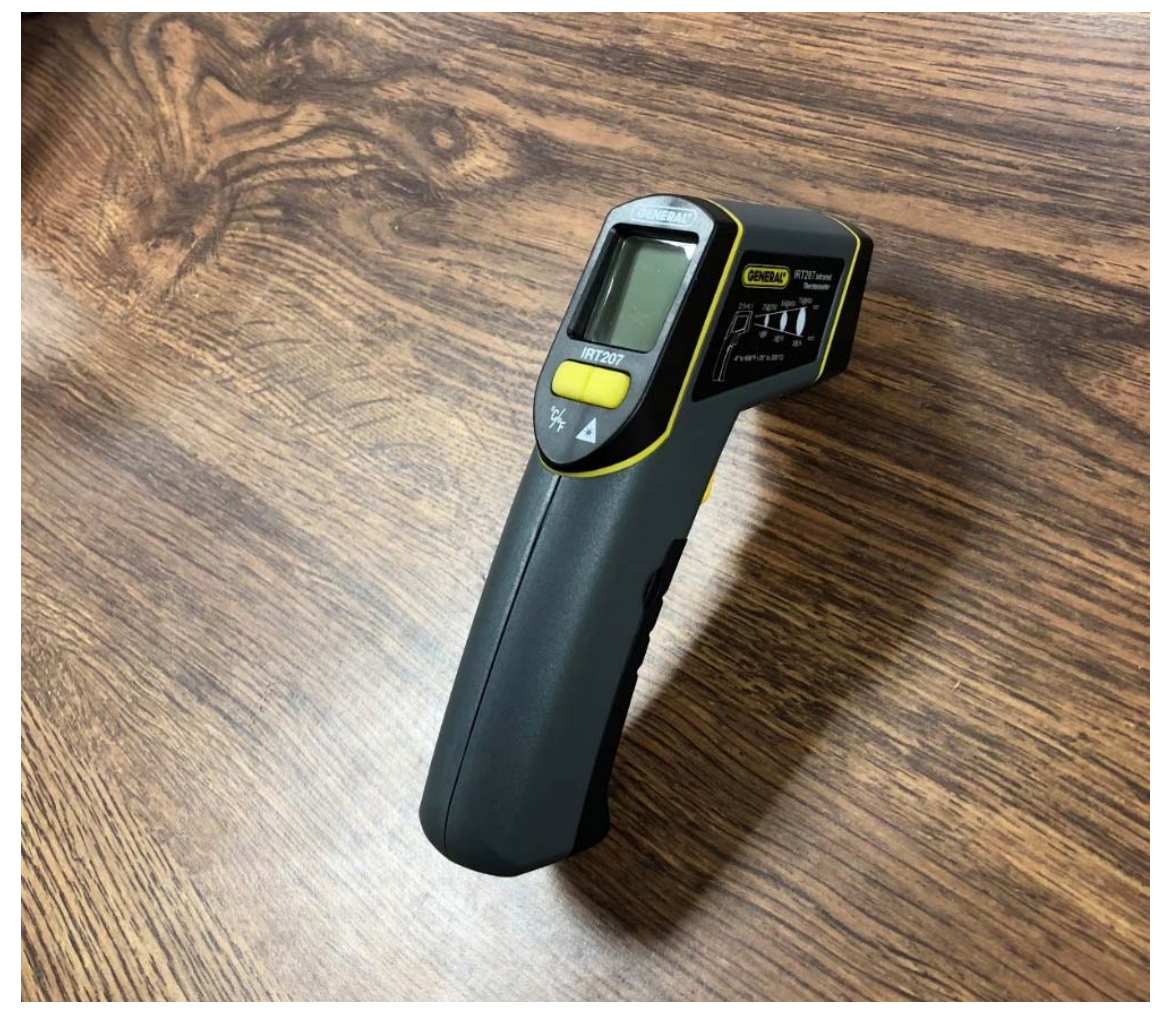

Figure 19. Infrared thermometer for ground surface temperatures 


\section{Results and Discussion}

\subsection{Field Site Construction and Completion}

The work was awarded by WVDEP on a lowest bidder basis to Aspen Construction, who began site construction on August 28, 2017. The tests plots were to be constructed as described in Section 3.3 and 3.4. The construction process began with improvement of the access road, a necessary initial task to accompany the paper fiber delivery. The area was regraded to take form of the test plots, including the hydraulic barrier. The channel was installed, followed by the growth layer and seeding. The short paper fiber was delivered onsite on August 30, 2017 provided by WestRock paper mill in Covington, VA (called $\mathrm{MGro}^{\mathrm{TM}}$ ). Water collectors were installed in the following month, and then no further changes were implemented (Figure 20). Equipment used in construction were an excavator (CAT 316E with a $1 \mathrm{yd}^{3}$ bucket) and a bulldozer (CAT D6R). The following sections describe the main construction details.

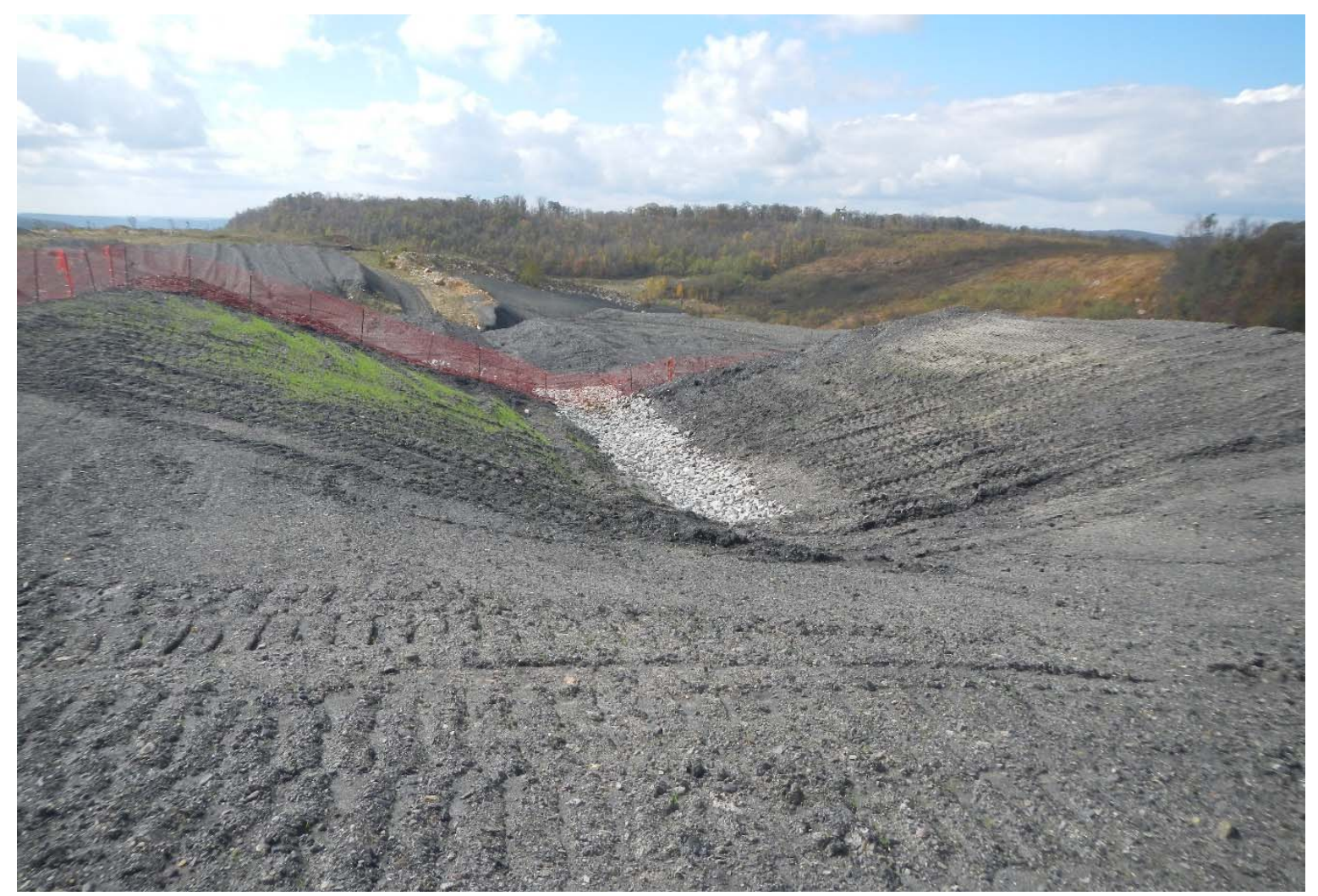

Figure 20. Completed test plots 


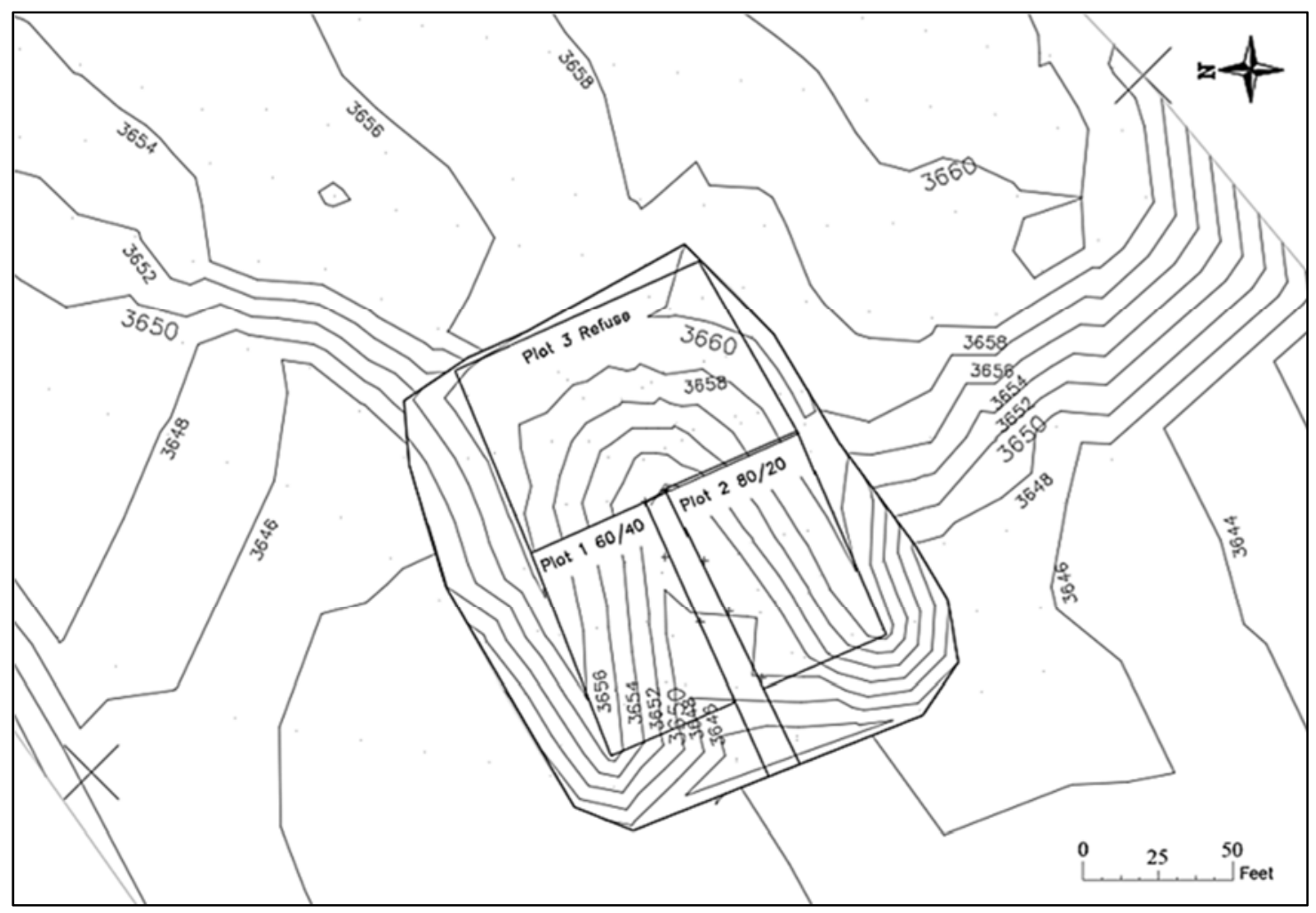

Figure 21. Topographical view of test plots (2-ft contour intervals)

\subsubsection{Regrading}

The first part of the construction was regrading the area to the design elevations. Material was borrowed from the immediately surrounding area and transported with the bulldozer (Figure 22). Slopes and final elevations were roughly formed and then adjusted with final regrading. The backslope of the plots to the existing ground was built at a $1 \mathrm{H}: 1 \mathrm{~V}$ slope $\left(45^{\circ}\right)$. According to the final survey (Figure 23), the total fill volume needed for construction was $399 \mathrm{yd}^{3}$. This is less than expected for this version of construction, which was expected to use $688 \mathrm{yd}^{3}$ of fill. 


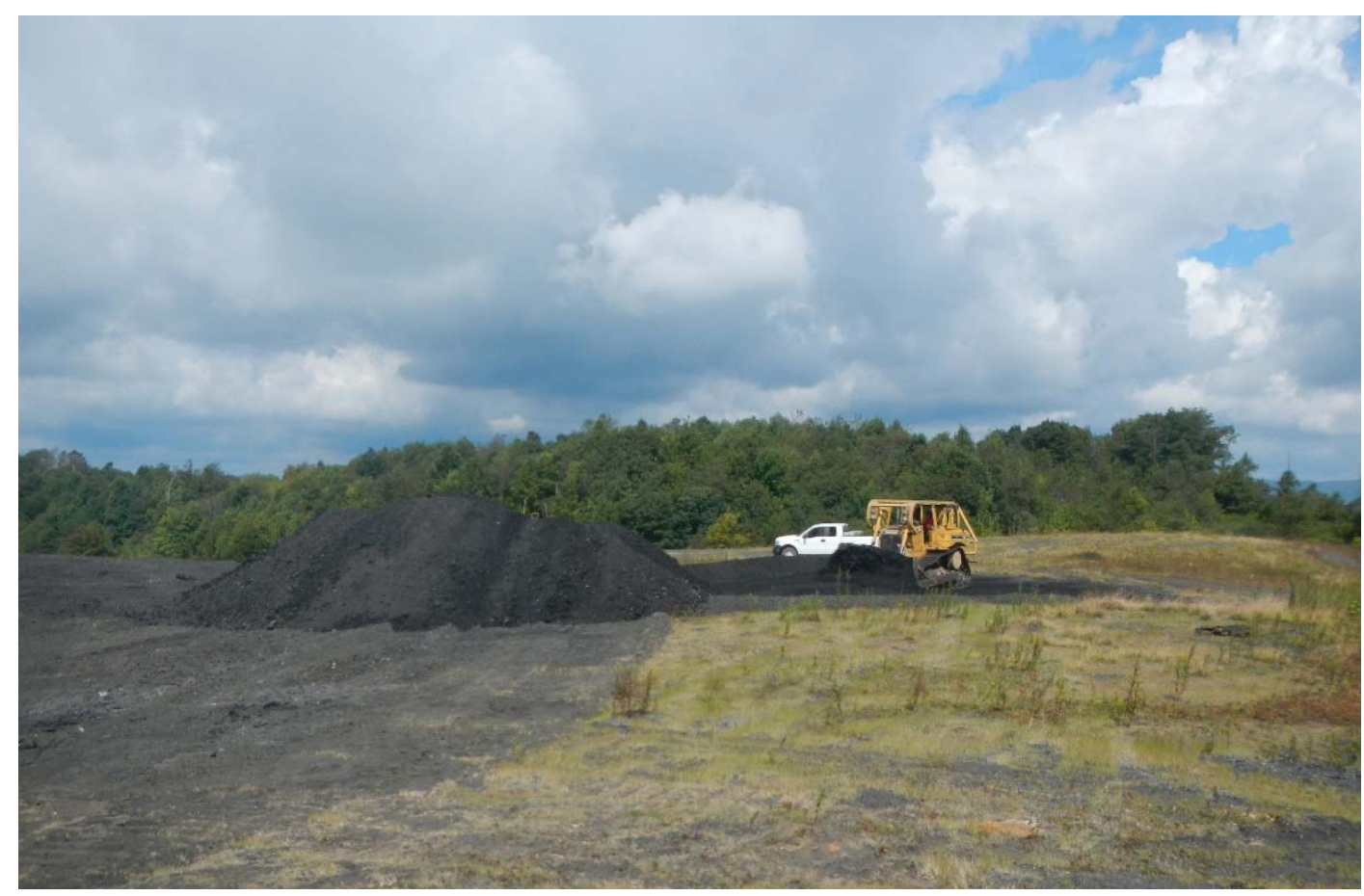

Figure 22. Onsite material used for regrading

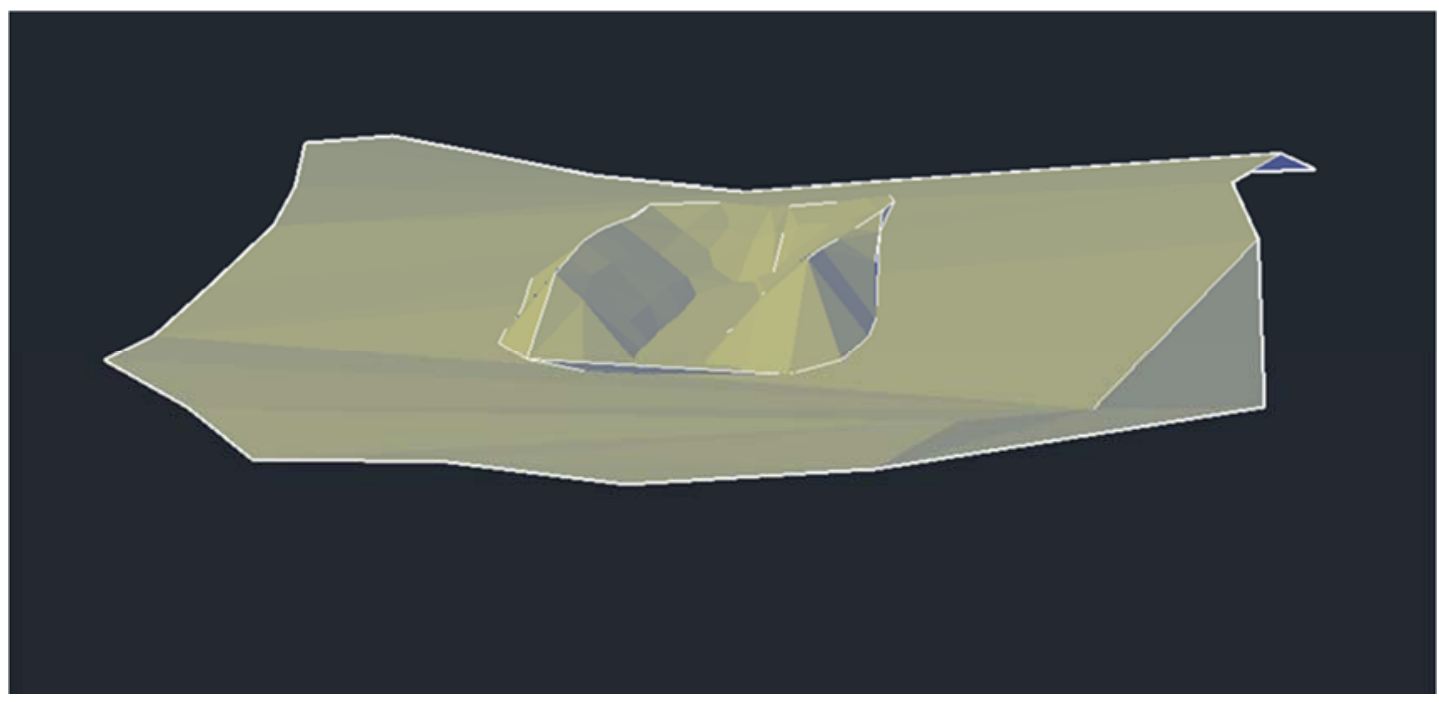

Figure 23. Final survey data modeled in Civil 3D (no vertical exaggeration)

The large difference in material needed to form the plots lead to a questions of what changed between the proposed design and what has been built. The final elevations do not exactly match at the highest points of the slopes around all of the plots. They were proposed to be at an elevation of $3665.5 \mathrm{ft}$, but the closest any of the final elevations came was $3661.3 \mathrm{ft}$ (Figure 24, Figure 25, and Figure 26). The lowest elevation, which is the bottom of the channel 
is proposed at $3642.8 \mathrm{ft}$ and was nearly the same elevation in the final survey at $3642.1 \mathrm{ft}$. This means that minimal vertical translation of the plots had occurred, but the total height was at least $4.2 \mathrm{ft}$ lower at the top of the slopes. In the same horizontal footprint, less change in height over a given distance would lead to less of a slope. Slope of the plots range from $8.3^{\circ}$ to $18.4^{\circ}$. The targeted 3H:1V slope was still reached in the southwest portions of the two growth plots, plots 1 and 2.

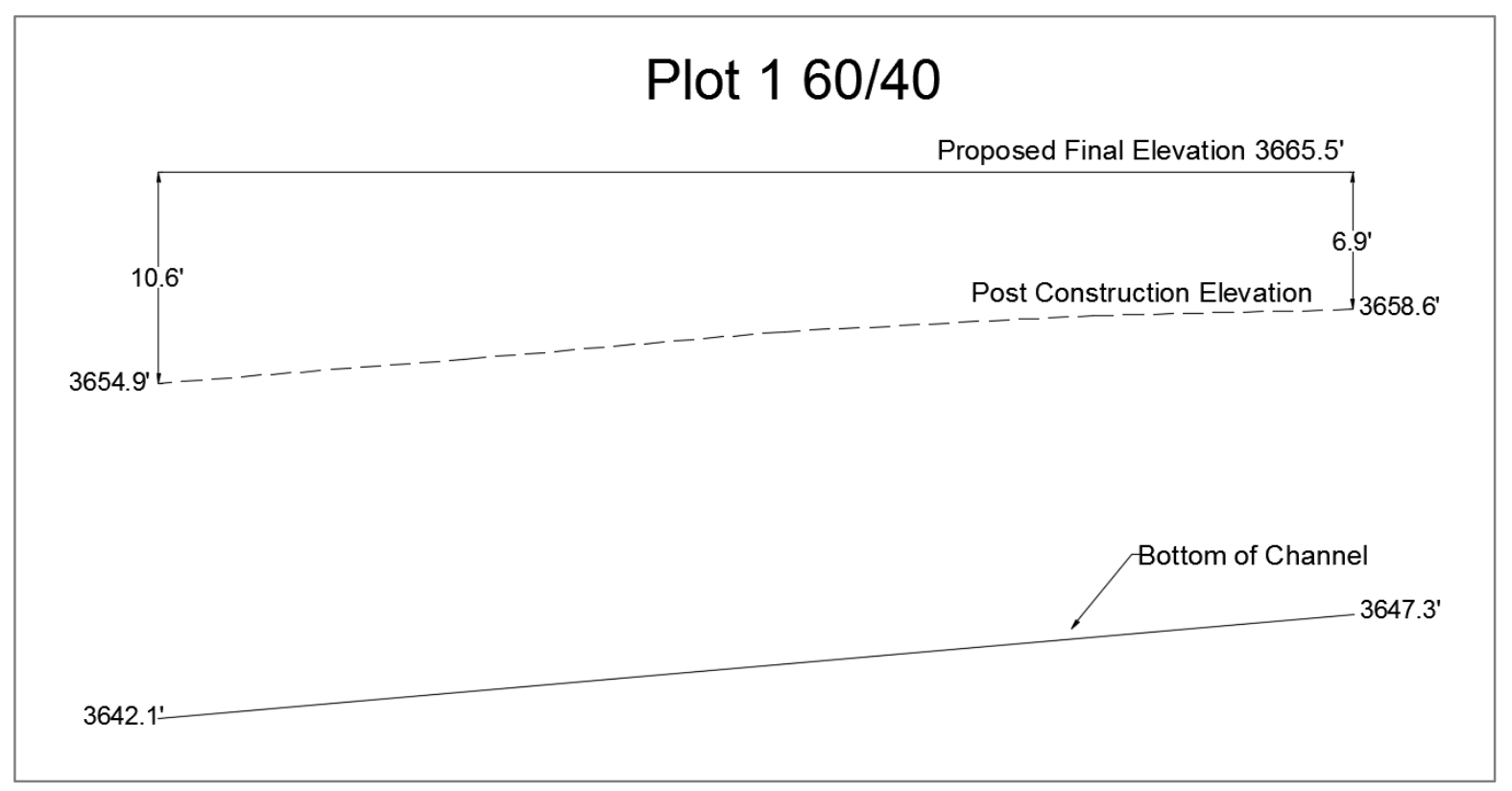

Figure 24. Final elevation differences in plot 1 


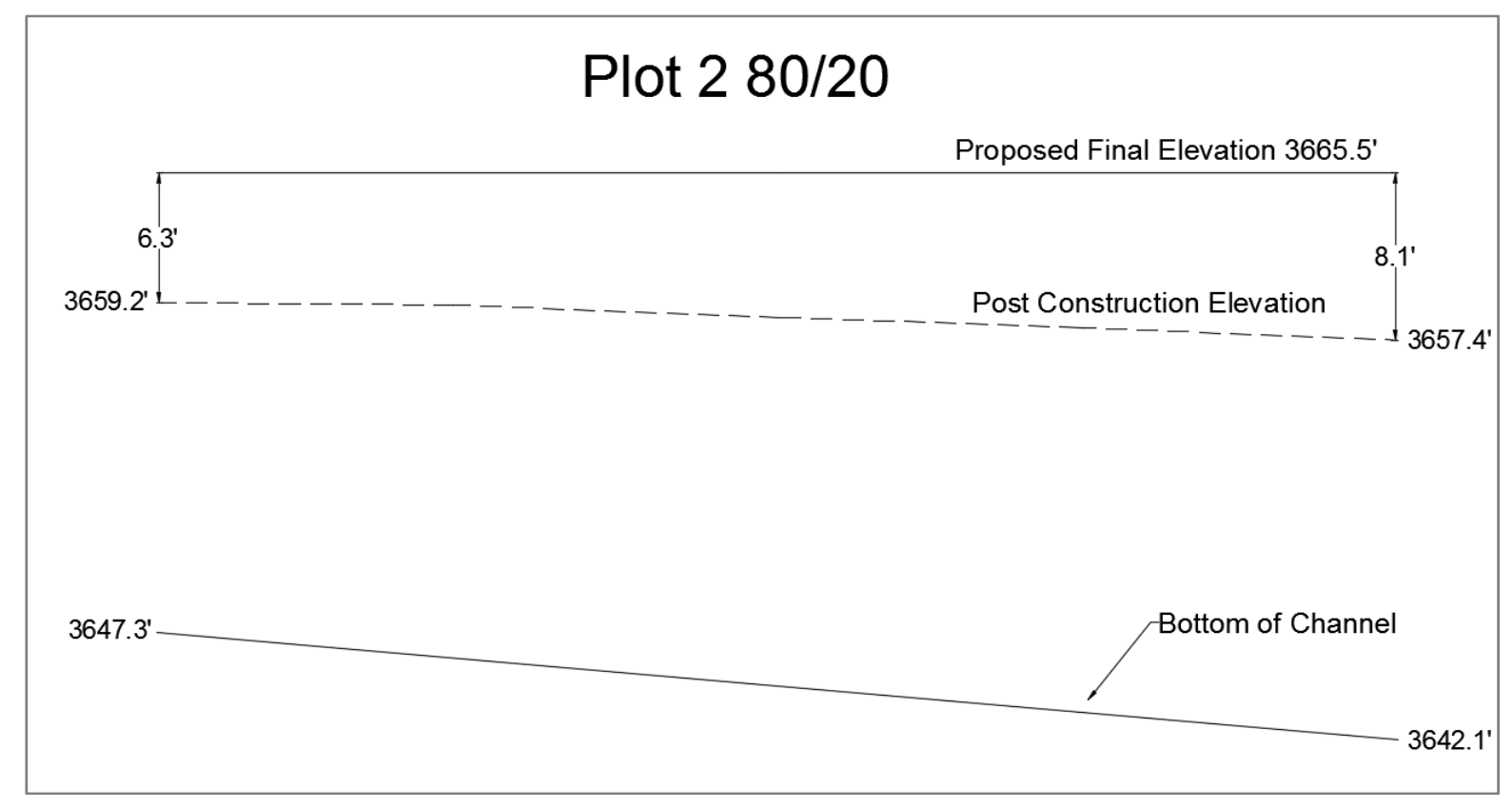

Figure 25. Final elevation differences in plot 2

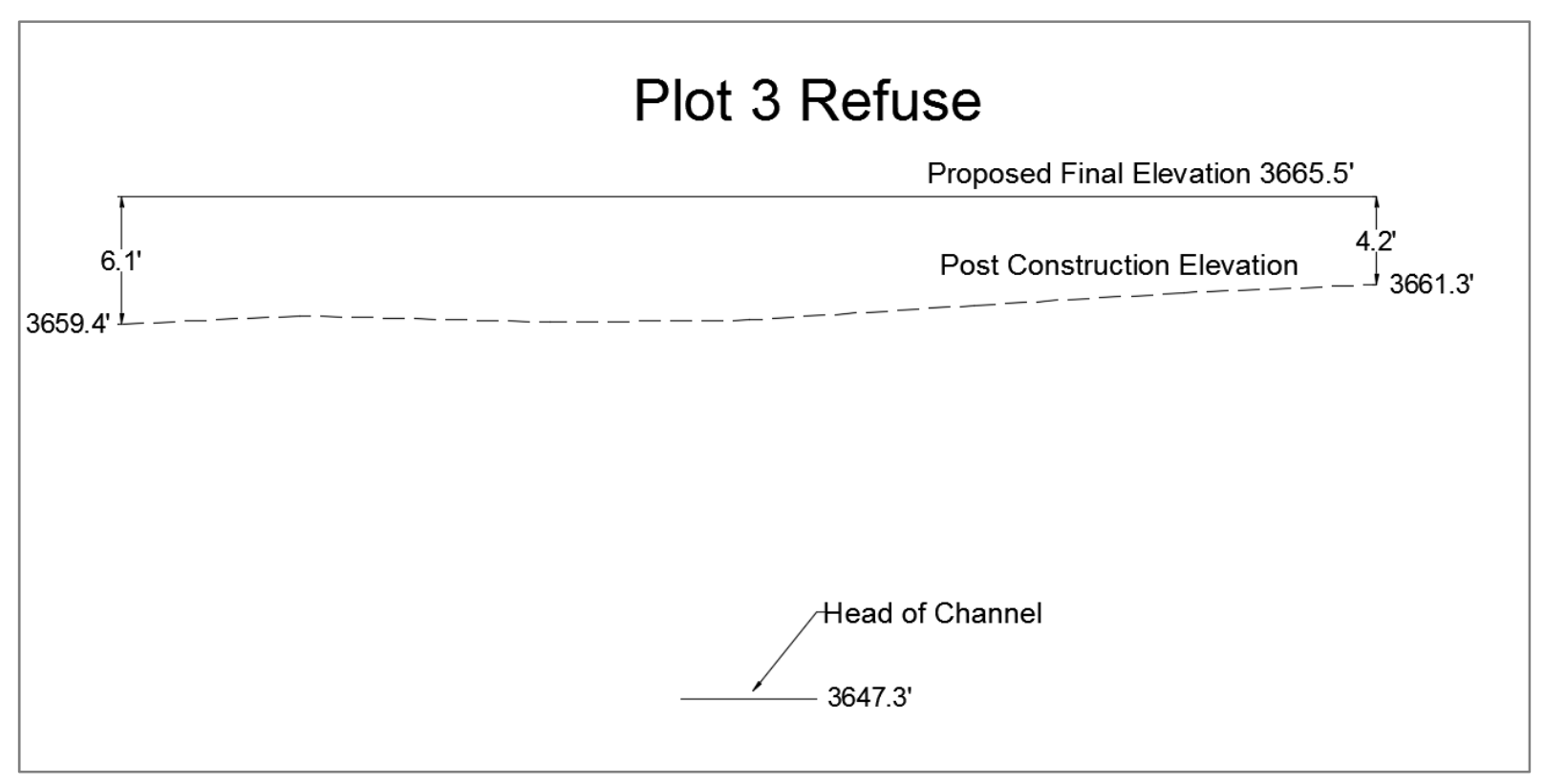

Figure 26. Final elevation differences in plot 3

\subsubsection{Channel}

After regrading, the channel was cut below the final grade. The area beneath the channel was also tracked in with the excavator, increasing compacted level to simulate the hydraulic barrier. Sandstone gravel with 9 in $\mathrm{D}_{50}$ lined the channel (Figure 27). There was no filter material 
added to the channel. Survey of the channel shows an elevation difference of $5.2 \mathrm{ft}$ in its run of $73.2 \mathrm{ft}$. The slope is $7.1 \%$, versus the proposed $10 \%$.

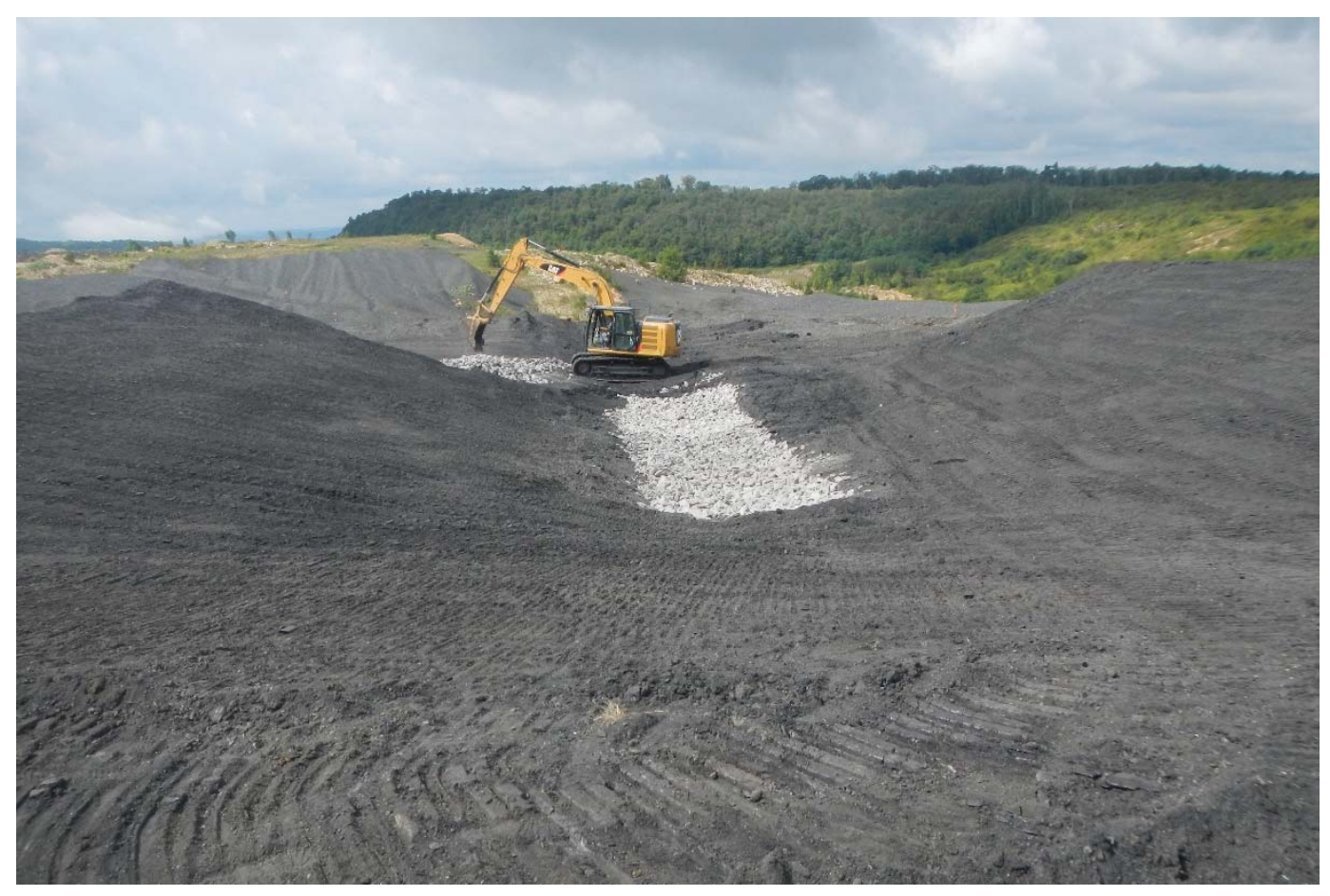

Figure 27. Gravel placement in geomorphic channel

\subsubsection{Hydraulic Barrier}

Rather than borrowing new material to compact for the hydraulic barrier, the outermost layer after regrading was used as the hydraulic barrier. The refuse was compacted by tracking the bulldozer over the refuse without blading. The design included compaction of multiple layers with a vibratory roller to achieve the required $95 \%$ of maximum dry density. It was decided that the roller could not be safely operated on the slopes and compaction would have to be met with another method. Density testing was conducted by Terradon Corporation on the third day of construction using a Troxler 3440 moisture and density gauge (Table 5). 
Table 5. Density testing summary

\begin{tabular}{|c|c|c|c|c|}
\hline Density Reading Location & $\begin{array}{c}\text { Dry } \\
\text { Density } \\
\left(\mathrm{lb} / \mathrm{ft}^{3}\right)\end{array}$ & $\begin{array}{c}\text { Percent } \\
\text { Compaction } \\
(\%)\end{array}$ & $\begin{array}{c}\text { Moisture } \\
\text { Content } \\
(\%)\end{array}$ & $\begin{array}{c}\text { Pass or } \\
\text { Fail }\end{array}$ \\
\hline Target Values & 95.6 & $>95 \%$ & $12.2-16.2$ & \\
\hline Remediation Left Bank & 72.1 & $74 \%$ & 23.1 & Fail \\
\hline Remediation Left Bank & 74.8 & $74 \%$ & 21.2 & Fail \\
\hline Remediation Right Bank Lower & 59.4 & $59 \%$ & 24.6 & Fail \\
\hline Remediation Right Bank Mid & 68.7 & $68 \%$ & 26.3 & Fail \\
\hline Remediation Right Bank Upper & 74.8 & $74 \%$ & 28.3 & Fail \\
\hline
\end{tabular}

In each of the density tests, the moisture content is well outside of the allowable range. Material dry density will increase as water is added up to the optimum moisture content. Beyond that, water begins to take up the voids that would have otherwise been occupied by the solid particles (Das and Sobhan, 2016). With compaction not reaching the required densities, the infiltration rate will likely be higher than designed.

\subsubsection{Growth Layer Mixing and Placement}

Multiple techniques were explored for mixing and placing the paper fiber-coal refuse blends. The proposed technique in section 3.4.4 was to mix the required ratios with the excavator bucket, but with the large amount of material to be mixed for the test plots, and ultimately the entire site reclamation, this method would be too time consuming.

The first method attempted on site was to spread a layer of paper fiber onto the hydraulic barrier with a bulldozer followed by a proportional layer of refuse on top of the paper fiber (Figure 28). For the 60/40 plot, the paper fiber was spread 8 inches thick with a 12 in. layer of refuse. This maintains the 3 parts refuse to 2 parts paper fiber and also leaves behind a $1 \mathrm{ft}$ growth layer after mixing, since the paper fiber takes the volume of the refuse voids. The growth layer for the 80/20 plot was 3 inches thick with a 12 in. refuse layer on top. 


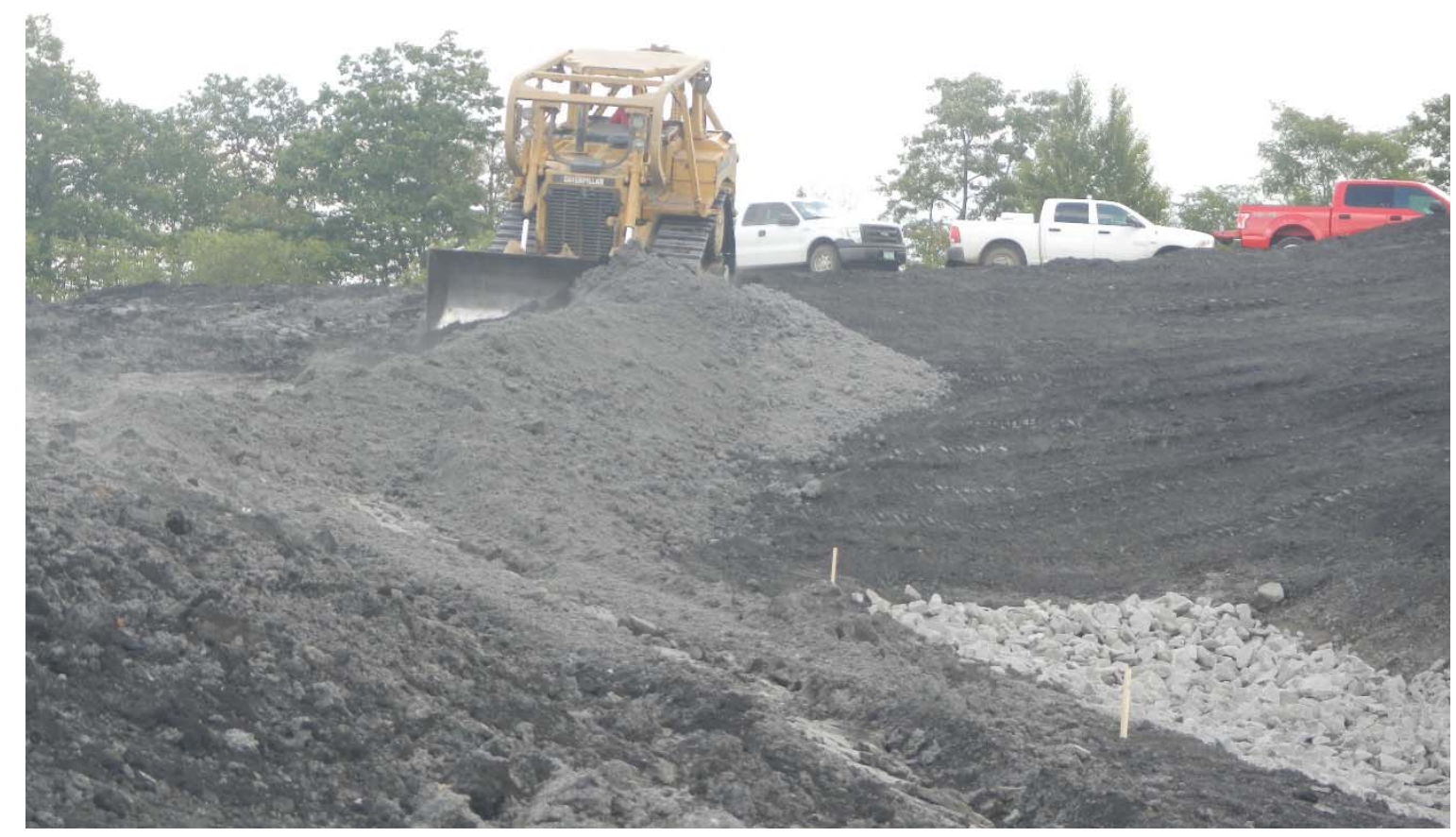

Figure 28. Spreading paper fiber for growth layer

The idea behind this method was that the bulldozer tracks would help adequately mix the materials while they were being spread. This was not the case and the materials stayed separated in the layers that they were placed (Figure 29). The paper fiber became compacted similar to a clay and did not allow mixing with the refuse. The blade of the bulldozer was then used to scrape the paper fiber and refuse of the growth layer and mechanically work the materials together on the plots in a second attempt (Figure 30). 


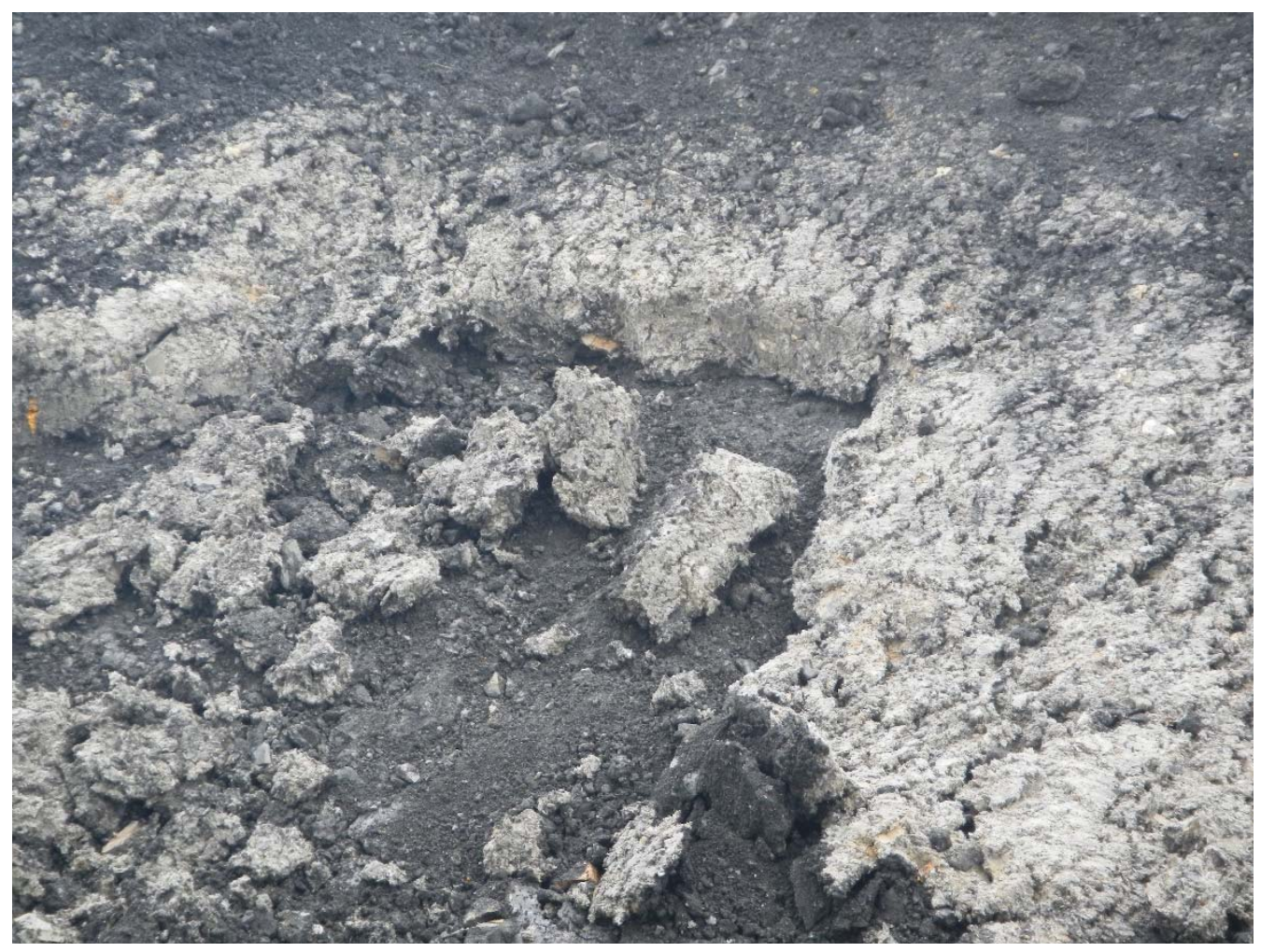

Figure 29. Unsuccessful blending of growth layer materials

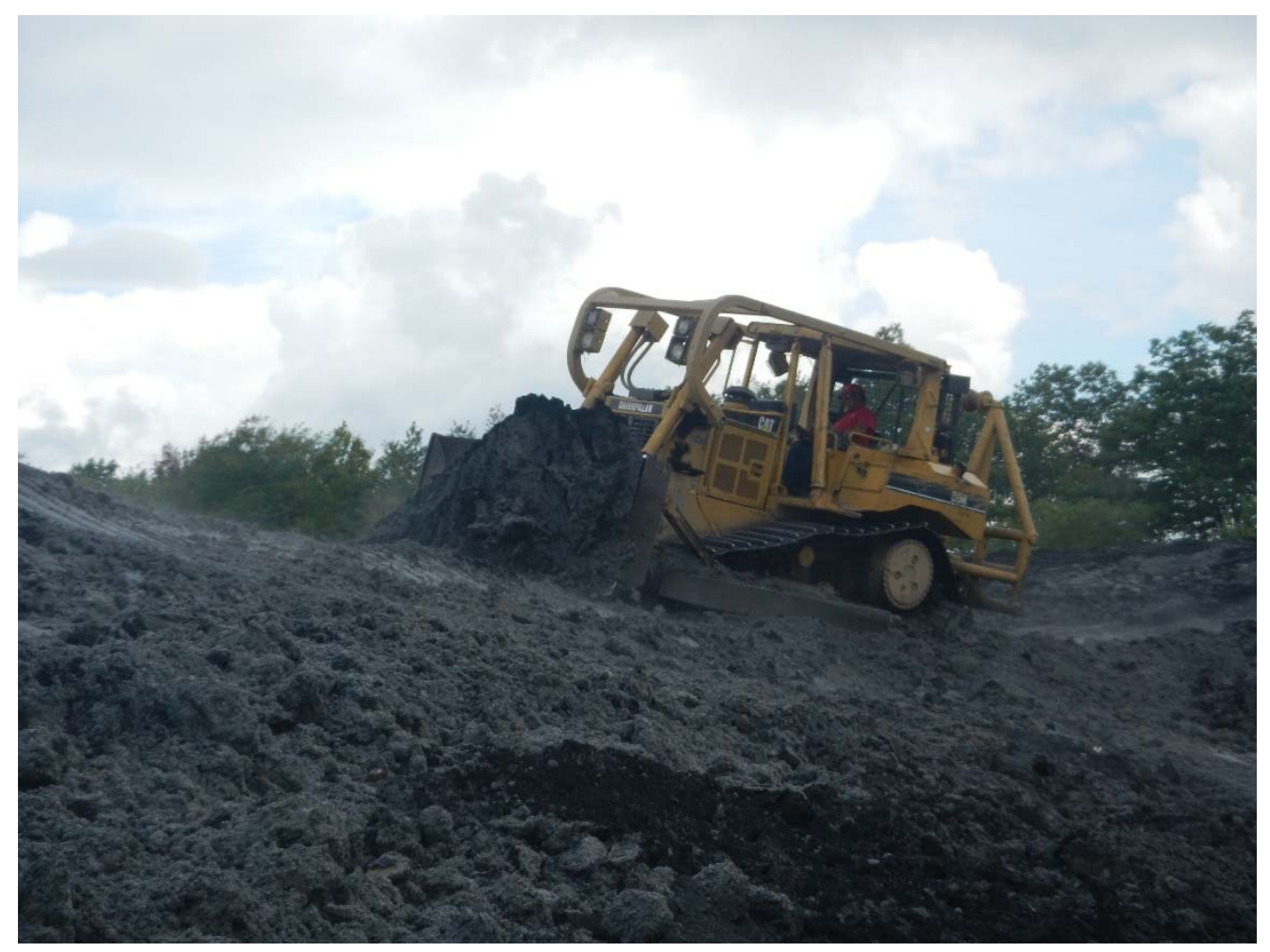

Figure 30. Scraping the growth layer for better blending 
The additional mixing created a slightly better blend than the first trial but still had large clumps of paper fiber with no refuse mixed in. The compaction of the paper fiber from the first attempt left the paper fiber in a more difficult condition for mixing than when the material arrived on site, as seen by later mixing trials.

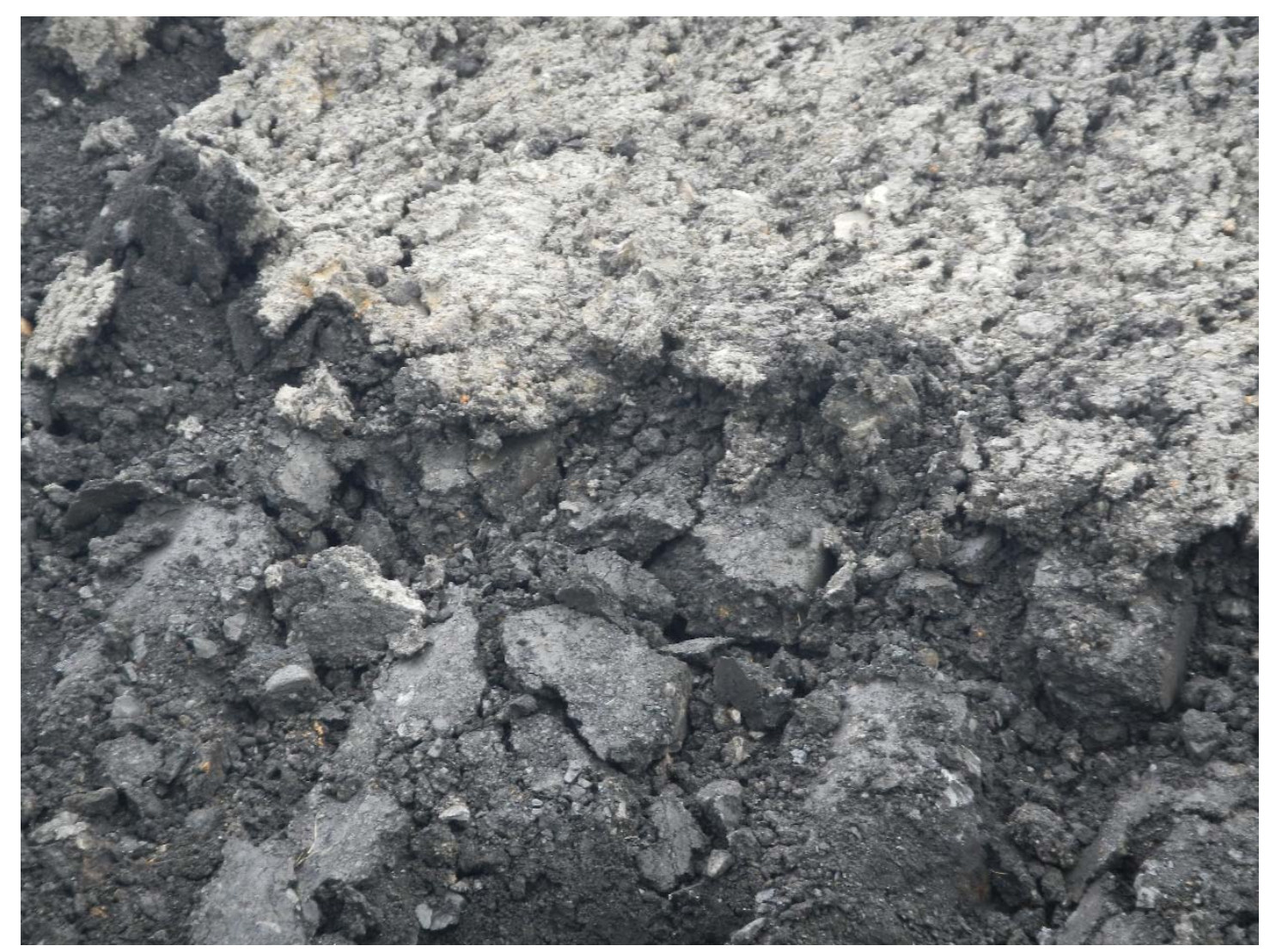

Figure 31. Second failed attempt of growth layer mixing

After a couple of failed attempts of spreading before mixing, the original recommendation was tested, to mix before spreading. Both the refuse and paper fiber were in large piles. For the $60 / 40$ blend mixture, three full excavator bucket scoops $\left(3 \mathrm{yd}^{3}\right)$ of refuse were mixed with every two buckets $\left(2 \mathrm{yd}^{3}\right)$ of paper fiber (Figure 32$)$. The excavator operator then mixed the smaller pile with the teeth of the bucket (Figure 33). 


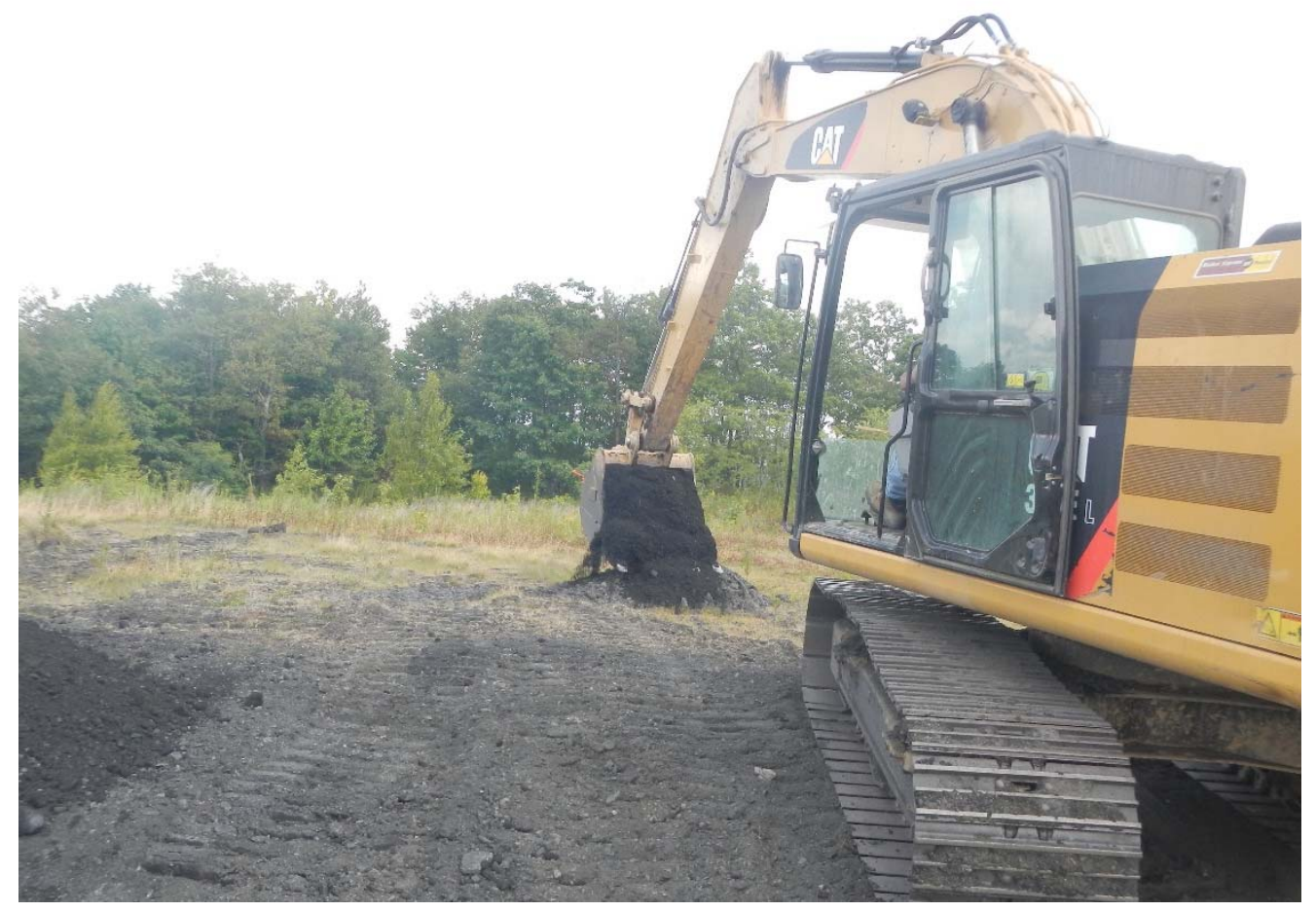

Figure 32. Bucket quantities to ensure correct mix ratios

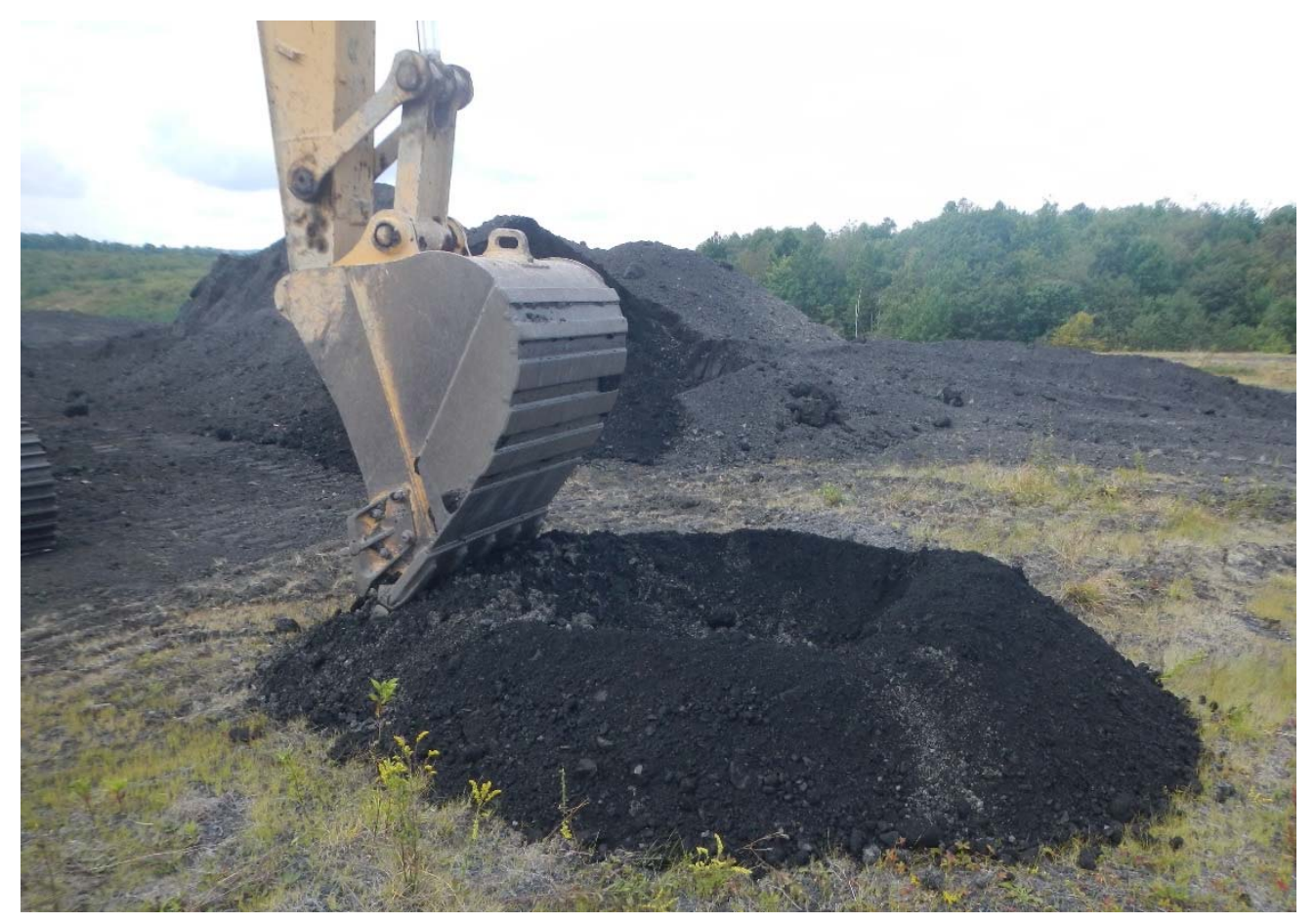

Figure 33. Mixing growth layer materials with excavator bucket teeth 
Next, a small tiller was used to mix the materials that were in layers from the previous attempts (Figure 34). The tiller was smaller than what could possibly be used for the full site reclamation but was studied conceptually. The tiller worked well in the top 4 inches, approximately. A tiller would need to be able to reach the entire growth layer for even mixing, a depth of 12 in. Large shale particles over 6 in may also present a hazard and damage the tiller.

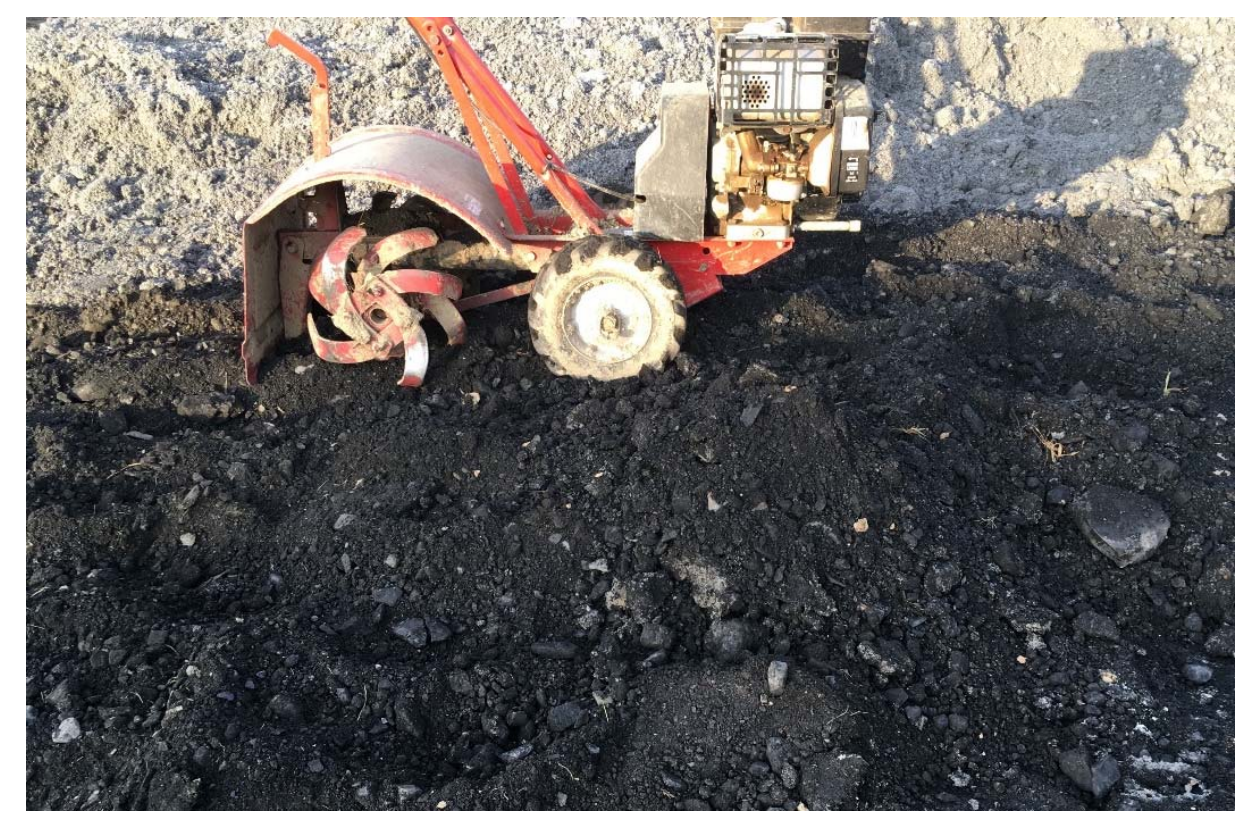

Figure 34. Small tiller for mixing

The growth layer for the $80 / 20$ blend plot was placed using material mixed with the excavator bucket before placement. However, the $60 / 40$ plot was placed before mixing. Instead of replacing the material to be mixed in the same method as the $80 / 20$ plot, the $60 / 40$ plot's unsuccessfully mixed layers were then remixed in place with the excavator bucket. This method did not mix as well as mixing before placing but was more uniform than the prior methods of placing before mixing.

\subsubsection{Seeding and Mulching}

The seed mixture was site specific and included orchardgrass, birdsfoot trefoil, red clover, annual ryegrass, bicolor lespedeza, and winter wheat. The wood cellulose fiber mulch was mixed with the seeding slurry and applied via hydroseeding (Figure 35). Seeding was completed September 4, 2017. 


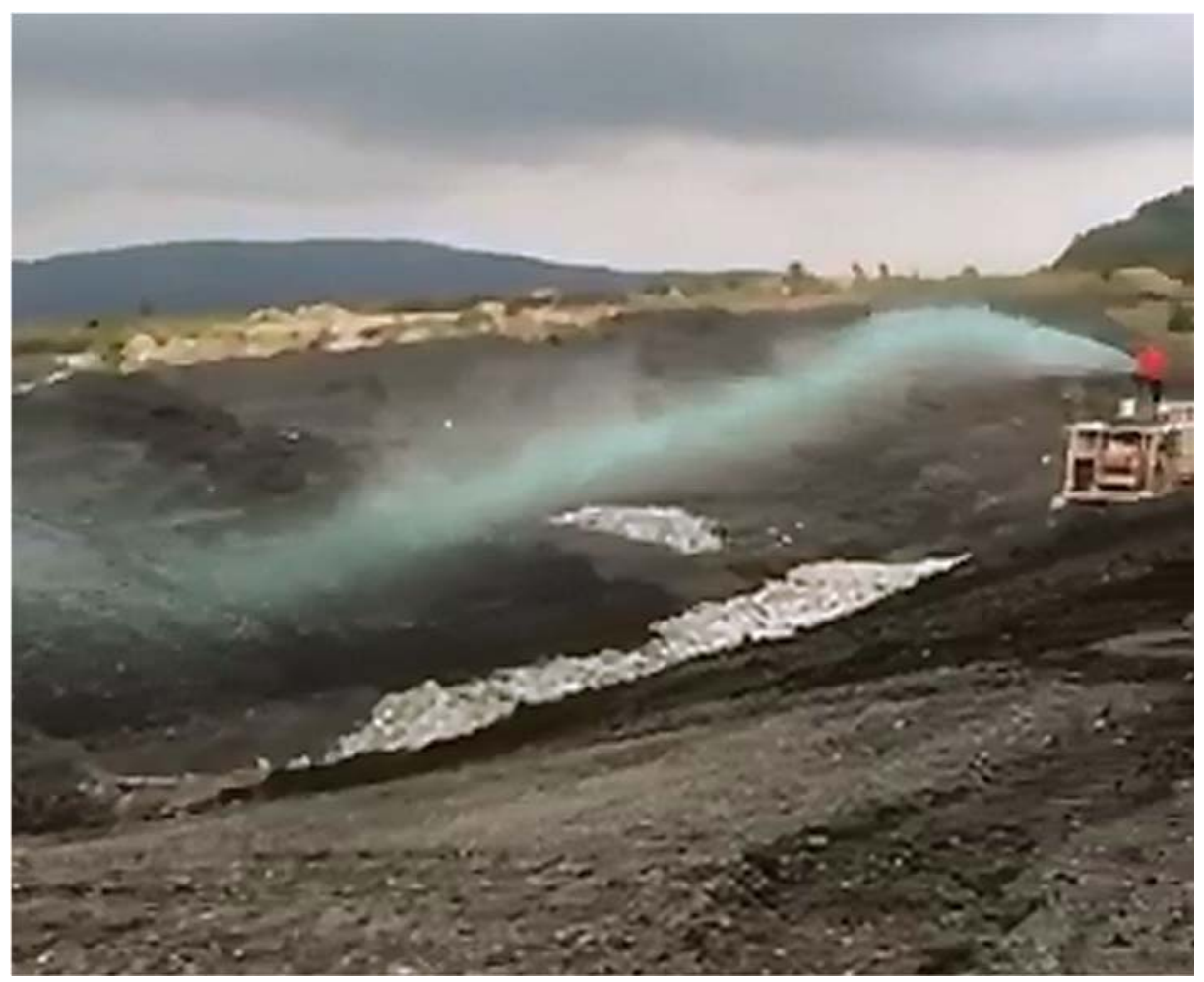

Figure 35. Hydroseeding application of seed and mulch (courtesy of Nathan Parks, WVDEP)

\subsubsection{Surface Runoff Collection}

Surface runoff collection devices were installed on each of the plots. Each collector was placed at the bottom of the slopes before entering the channel (Figure 36). They were located in areas that would allow the surface water to easily travel in natural channels to maximize the quantity of water for sampling (Figure 37). 


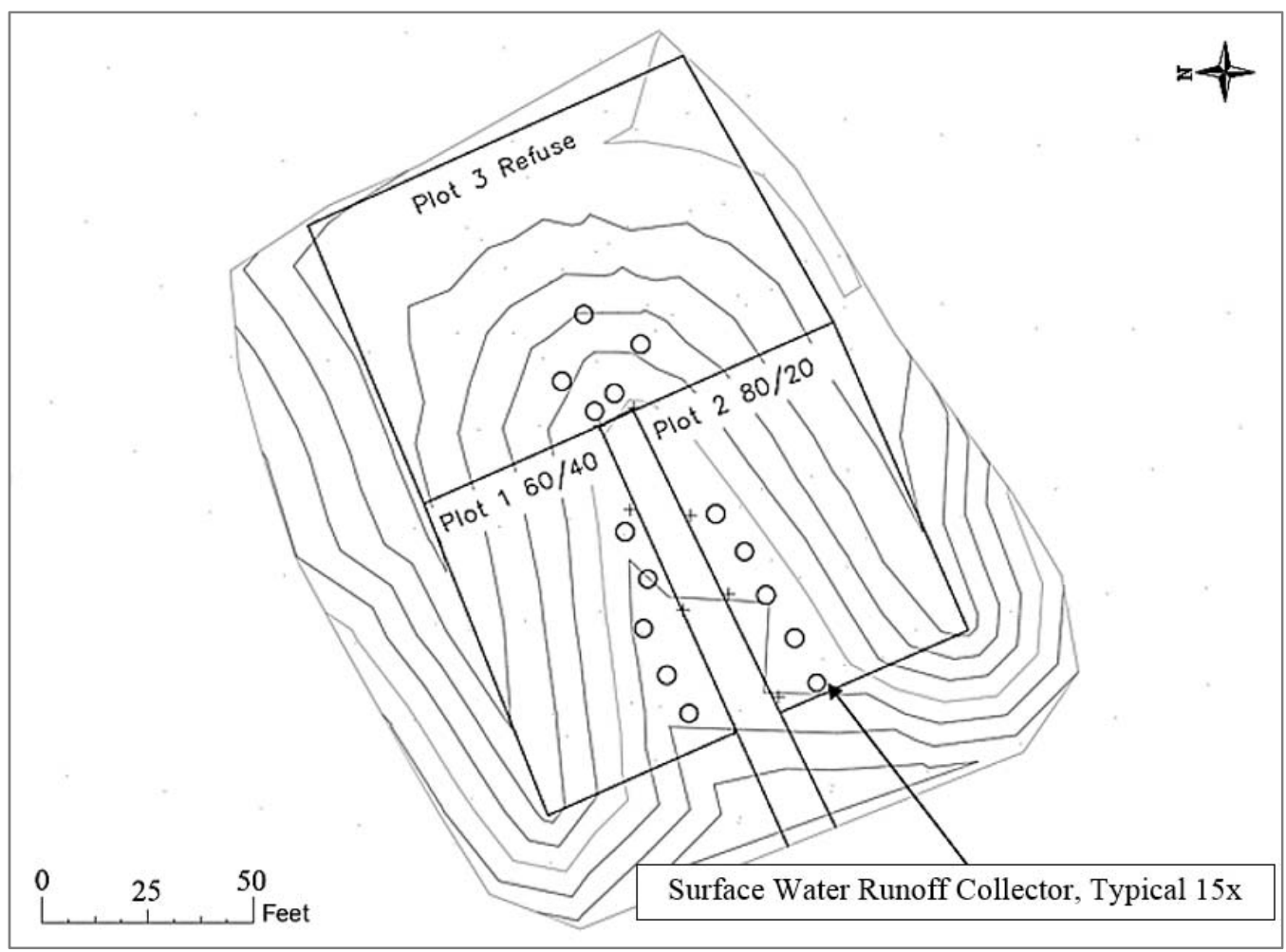

Figure 36. Survey location of each collector (2-ft contour intervals)

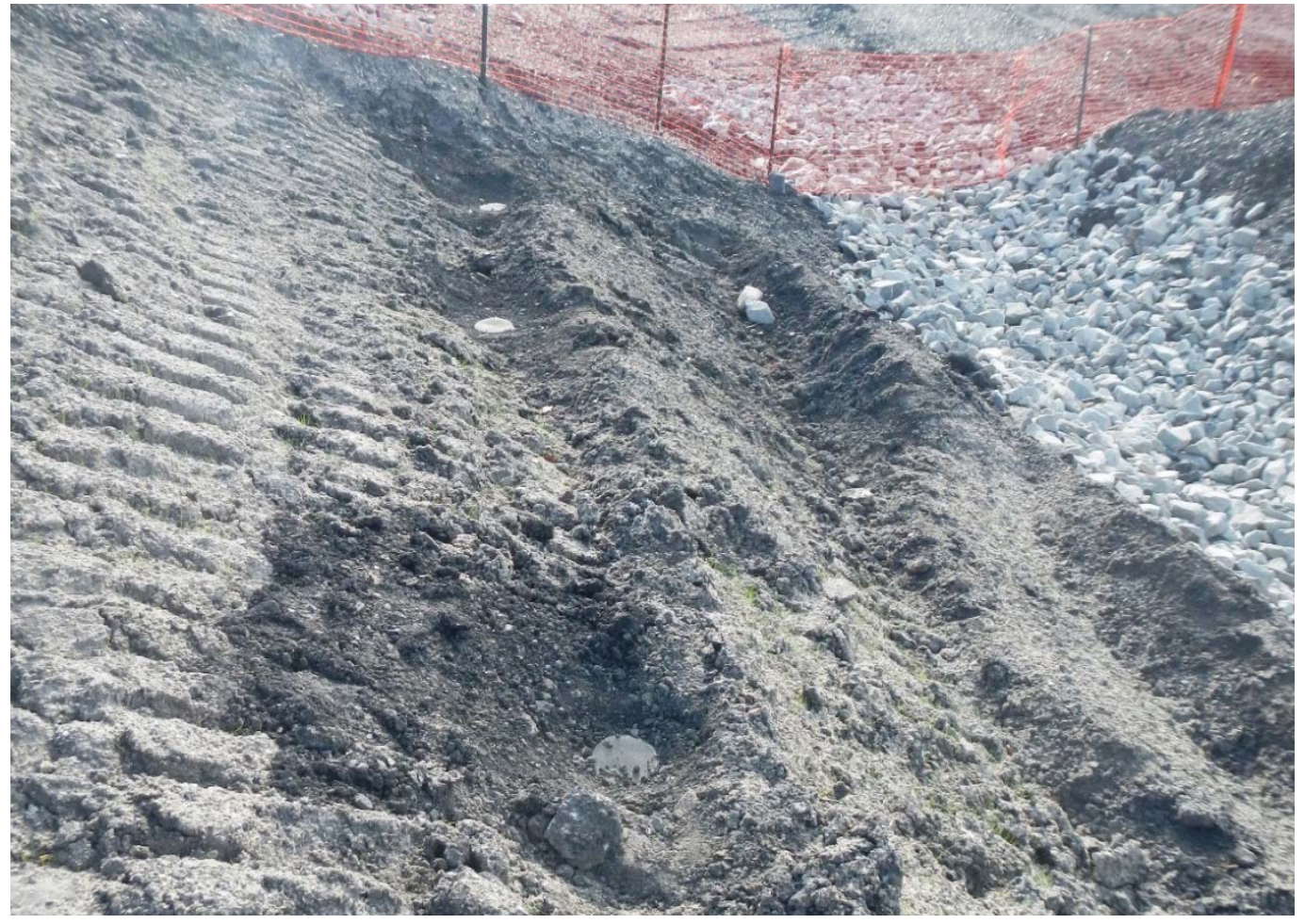

Figure 37. Water collectors placed in low areas to maximize sample volume 
In the first collection event, 100 percent of the maximum collection volume was retained in both plots 1 and 2 (Figure 38). The refuse area, plot 3, retained 78 percent of maximum capacity. On occasion, the collectors would be filled completely with coal refuse sediment and therefore would be discarded and not collected for sampling (Figure 39). Water would be taken from the five collectors on each plot and mixed together in a bucket before sampling (Figure 40).

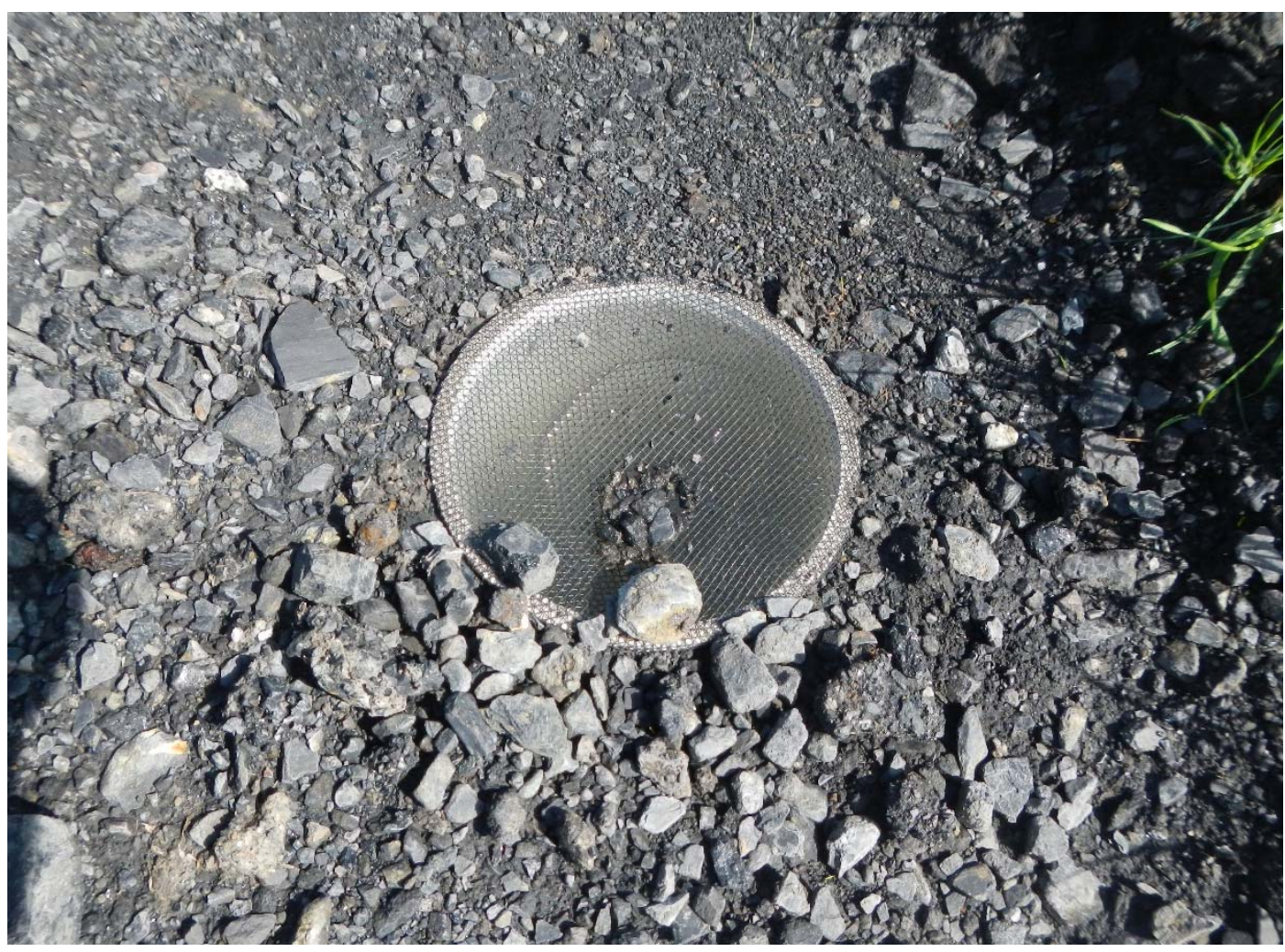

Figure 38. Water collector at $100 \%$ capacity 


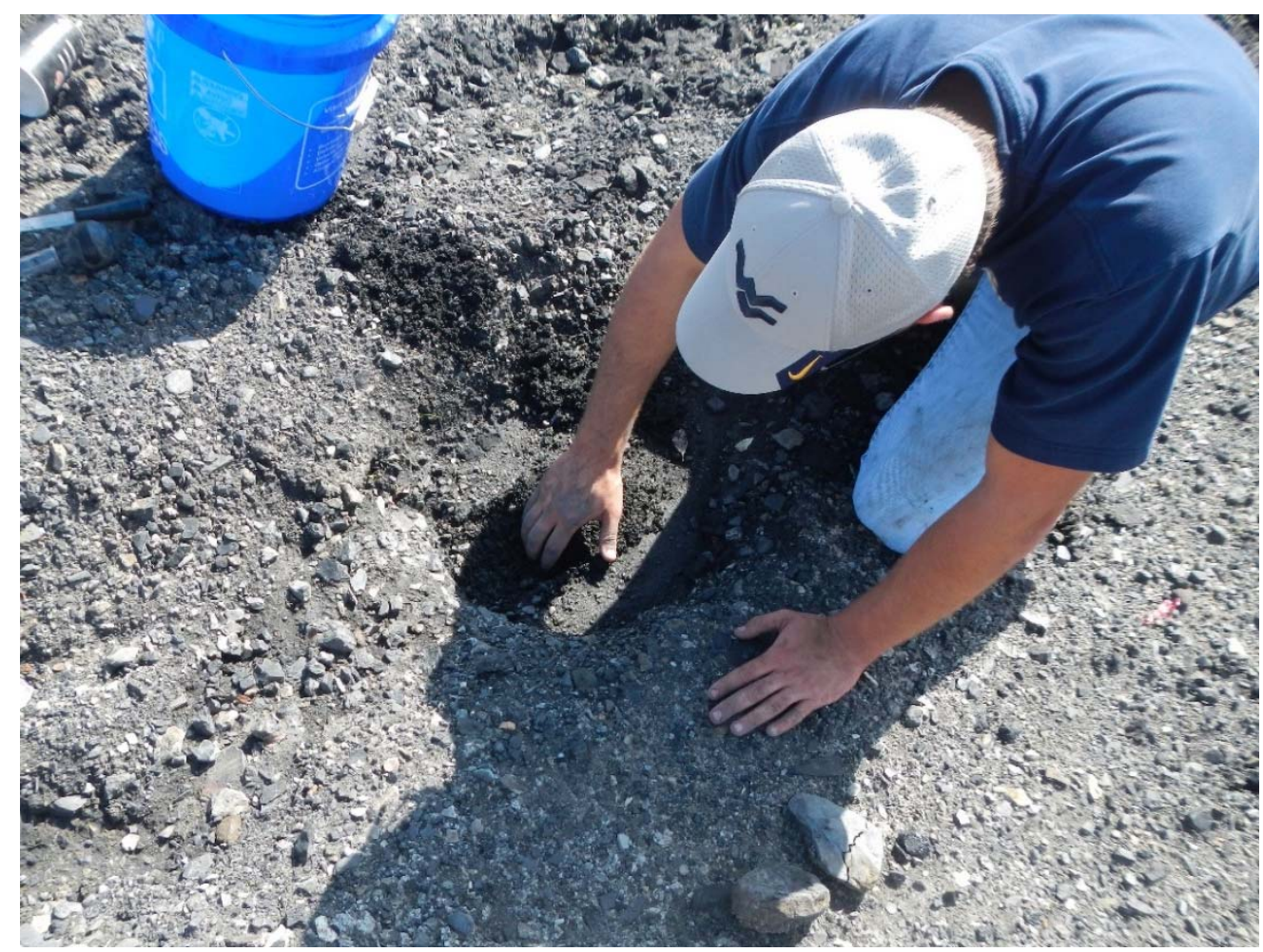

Figure 39. Water collector entirely filled and covered by coal refuse sediment

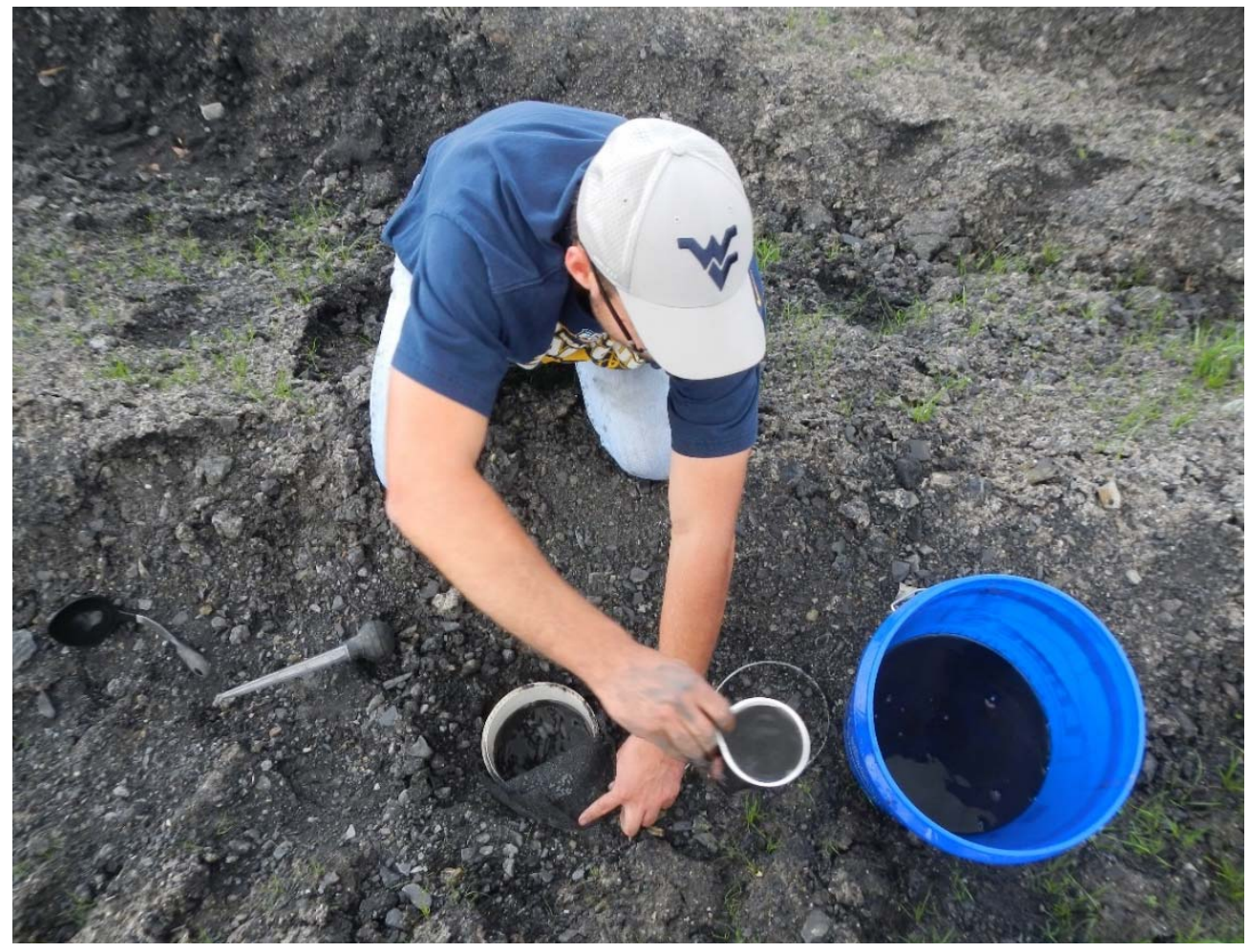

Figure 40. Bailing water for composite sampling 
Additional samples were collected from the channel when available. On heavy rainfall events, runoff would pond in the low end of the channel providing an opportunity for grab sampling (Figure 41). One liter of water would suffice for sampling.

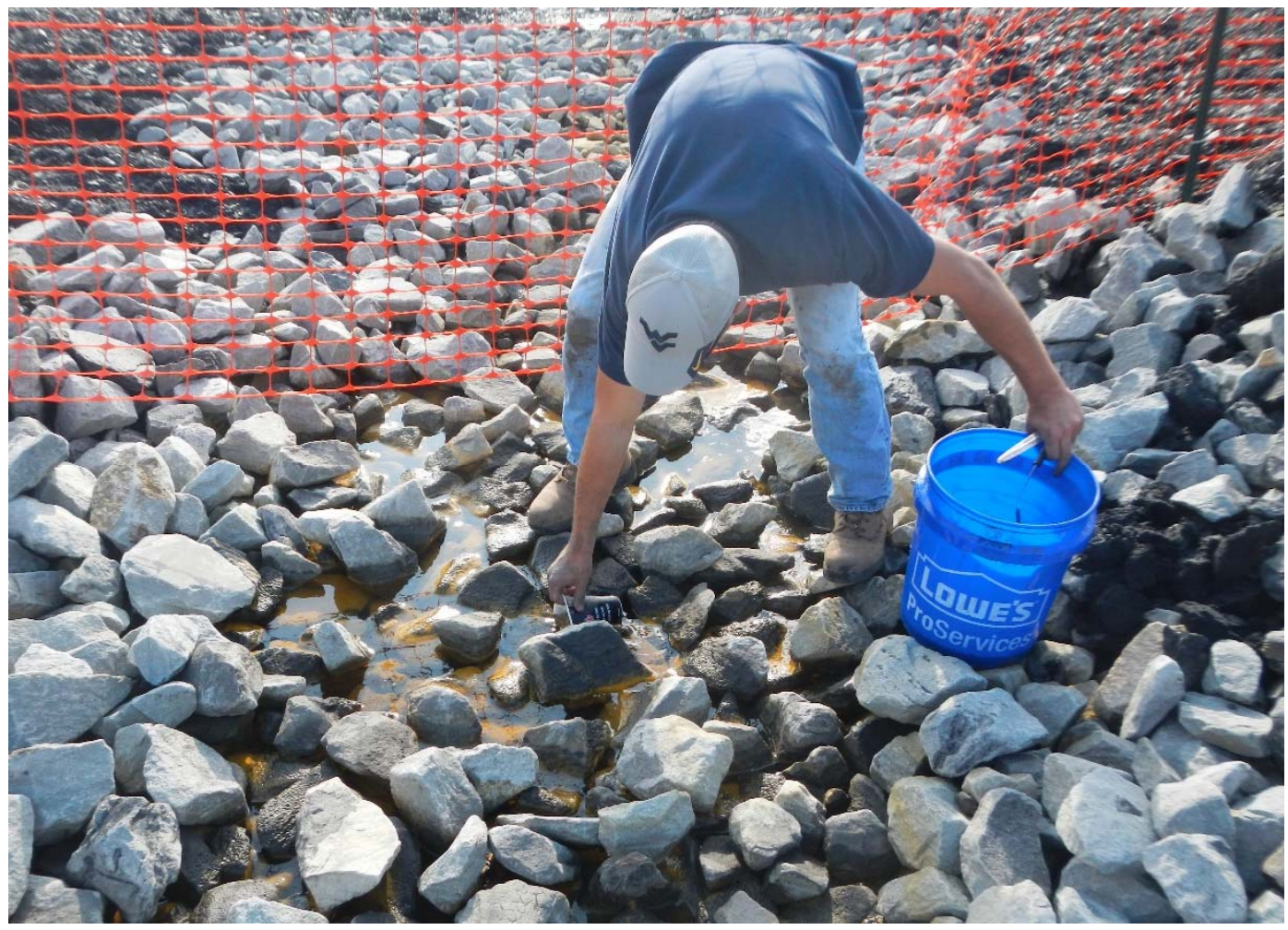

Figure 41. Grab sample from ponding within channel

\subsection{Site Monitoring}

Monitoring the test plots began at the completion of the site, September 4, 2017 and continued through spring 2018. Vegetation and water quality were monitored monthly in the fall, suspended because of weather during winter, and resumed in spring. Infiltration readings were taken before site disturbance, upon completion of the hydraulic barrier, and again through the hydraulic barrier in the spring.

\subsubsection{Infiltration Measurements}

The first infiltration measurements were completed in May 2017 in the area of the test plots before the site had been disturbed by equipment and regrading. As compaction requirements were not met for the hydraulic barrier, infiltration rates were expected to be high. Infiltration rates before disturbance was $2.16 \mathrm{in} / \mathrm{hr}$ and increased in the hydraulic barrier $5.6 \%$ to 
an average of $2.28 \mathrm{in} / \mathrm{hr}$ across the $60 / 40,80 / 20$, and refuse areas in initial testing following construction (Table 6). Since the material had been originally placed nearly 20 years ago, the in situ material had a minimum number of air voids due to settlement and consolidation over time. By disturbing and transporting the refuse, air was reintroduced into the voids and was not recompacted.

Table 6. Hydraulic barrier infiltration across all plots

\begin{tabular}{|c|c|c|}
\hline Refuse Material & $\begin{array}{c}\text { Infiltration } \\
(\mathrm{in} / \mathrm{hr})\end{array}$ & $\mathrm{R}^{2}$ \\
\hline Refuse before disturbance (05/17) & 2.16 & 0.3084 \\
\hline Hydraulic Barrier (average for all plots, 09/27/17) & 2.28 & 0.9167 \\
\hline
\end{tabular}

The 60/40 and 80/20 growth layers were both placed as uncompacted layers and reported infiltration rates of $3.70 \mathrm{in} / \mathrm{hr}$ and $2.27 \mathrm{in} / \mathrm{hr}$ (Table 7). These values may vary because of the difference in placement technique. The 60/40 growth layer was handled nearly 3 times more than the $80 / 20$ layer, allowing more opportunity for introducing air into the voids, in addition to more organics.

Table 7. Growth layer infiltration

\begin{tabular}{|c|c|c|}
\hline Growth Layer & $\begin{array}{c}\text { Infiltration } \\
(\mathrm{in} / \mathrm{hr})\end{array}$ & $\mathrm{R}^{2}$ \\
\hline $60 / 40$ blend $(09 / 27 / 17)$ & 3.70 & 0.4592 \\
\hline $80 / 20$ blend $(09 / 27 / 2017)$ & 2.27 & 0.1955 \\
\hline
\end{tabular}

Assessing each plot individually, the hydraulic barrier under the 60/40 and 80/20 plots showed a reduction in infiltration from the undisturbed refuse, and more from the refuse plots (Table 8 ). The number of passes over plots 1 and 2 were greater than the passes over refuse plot 3. As the number of passes over a soil increase, the percentage of relative compaction will increase, while decreasing void ratio and permeability (Das and Sobhan, 2016). Infiltration testing was performed again in spring on the hydraulic barriers of plots 1 and 2. 
Table 8. Hydraulic barrier infiltration by area

\begin{tabular}{|c|c|c|c|}
\hline Refuse Material By Plot & $\begin{array}{c}\text { Infiltration } \\
\text { (in/hr) }\end{array}$ & $\begin{array}{c}\text { Reduction } \\
(\%)\end{array}$ & $\mathrm{R}^{2}$ \\
\hline Refuse before disturbance (05/17) & 2.16 & $\sim$ & 0.9167 \\
\hline Hydraulic barrier, plot 1 60/40 (09/27/17,3/31/18) & 1.54 & $29 \%$ & 0.5787 \\
\hline Hydraulic barrier, plot 2 80/20 (09/27/17,3/31/18) & 1.47 & $32 \%$ & 0.5416 \\
\hline Hydraulic barrier, plot 3 refuse (09/27/17) & 2.82 & $\begin{array}{c}-31 \% \\
\text { (increase) }\end{array}$ & 0.4223 \\
\hline
\end{tabular}

\subsubsection{Vegetation Growth}

Ground cover was monitored during the fall and spring growing seasons. Plot 2 saw higher ground cover percentages than plot 1 throughout the duration of the testing (Figure 42).

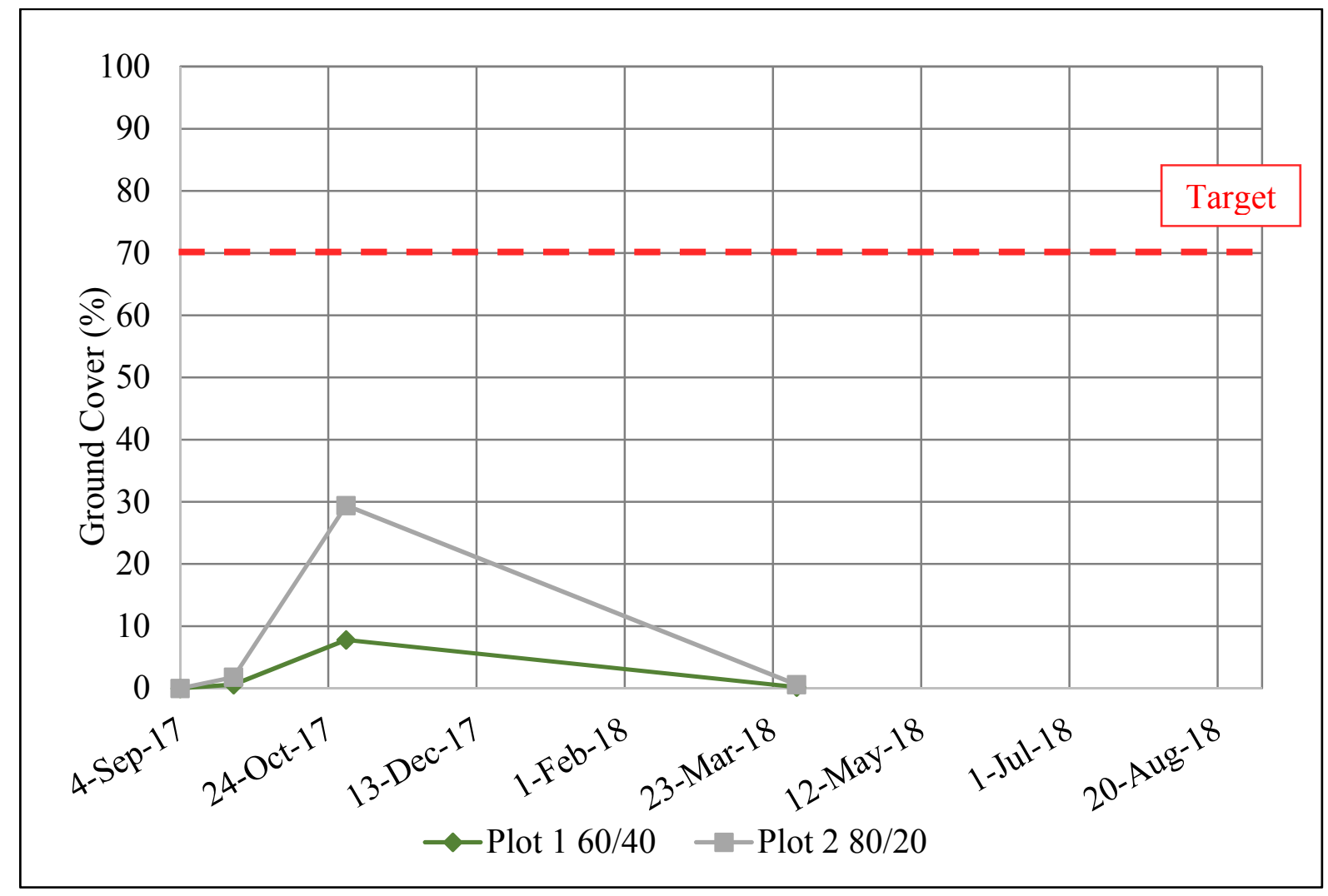

Figure 42. Growth layer vegetation versus time 
A portion of the variance in ground cover may be explained due to the slope aspect in which the growing planes of each plot lie. Plot 1 and 2 face opposite directions, plot 1 facing southeast and plot 2 facing northwest. A previous study on how slope aspect affects geomorphic dynamics of coal mining spoil heaps shows a positive correlation between slope aspect and vegetation cover. North-western slopes retain more moisture in the soil from less evaporation, only receiving evening sun and benefitting vegetation establishment efforts (Nyssen and Vermeersch, 2010).

An increase in sunlight exposure can increase water stress and ground temperatures (Sandholt et al., 2002). Water stress can constrain plant growth and decrease total nutrient content because of decreased uptake of water and nutrients, and die back of roots and shoots (Lenhart et al., 2015). These factors may explain the differences in success of establishing vegetation on plot 2 over plot 1, rather than only the intended difference of mixing proportion in the growth layer.

The decrease of the vegetation over the winter months is likely due to the biological inactivity of the grasses from low temperatures (Beard, 1973). The temporary fencing around the site had also become damaged in the winter months, which may have allowed deer onto the test plots and consume some of the vegetation.

\subsubsection{Water Quality Data}

Surface water runoff was collected from each of the three plots when weather allowed, and from ponding within the channel when available. Samples were collected for testing using an YSI field instrument and analysis by REI Consultants, Inc. The third round of sampling was only completed on the plots containing paper fiber, plots 1 and 2 . 
Table 9. Surface water runoff quality (10-11-2017)

\begin{tabular}{|c|c|c|c|c|}
\hline & Plot 1 60/40 & Plot $280 / 20$ & Plot 3 Refuse & Channel \\
\hline $\begin{array}{l}\text { Sample Volume } \\
\text { (gal) }\end{array}$ & 4.5 & 4.5 & 4.5 & 1.5 \\
\hline $\begin{array}{c}\text { Temperature } \\
\left({ }^{\circ} \mathrm{C}\right)\end{array}$ & 22.9 & 21.6 & 20.6 & 22.1 \\
\hline $\mathrm{pH}$ & 6.4 & 6.3 & 6.3 & 2.9 \\
\hline $\begin{array}{c}\text { Conductivity } \\
(\mu \mathrm{s} / \mathrm{cm})\end{array}$ & 891 & 1441 & 1526 & 3732 \\
\hline $\begin{array}{c}\text { Total Dissolved } \\
\text { Solids }(\mathrm{g} / \mathrm{L})\end{array}$ & 0.6 & 1.0 & 1.1 & 2.6 \\
\hline $\begin{array}{c}\text { Dissolved Oxygen } \\
(\mathrm{mg} / \mathrm{L})\end{array}$ & 4.3 & 4.6 & 3.9 & 7.4 \\
\hline $\begin{array}{c}\text { Aluminum } \\
(\mathrm{mg} / \mathrm{L})\end{array}$ & 14 & 8 & 6 & 163 \\
\hline $\begin{array}{l}\text { Calcium } \\
(\mathrm{mg} / \mathrm{L})\end{array}$ & 241 & 341 & 430 & 616 \\
\hline $\begin{array}{c}\text { Iron } \\
(\mathrm{mg} / \mathrm{L})\end{array}$ & 91 & 21 & 24 & 104 \\
\hline $\begin{array}{c}\text { Magnesium } \\
(\mathrm{mg} / \mathrm{L})\end{array}$ & 13 & 19 & 20 & 107 \\
\hline $\begin{array}{c}\text { Manganese } \\
(\mathrm{mg} / \mathrm{L})\end{array}$ & 0.6 & 0.6 & 0.3 & 21 \\
\hline $\begin{array}{l}\text { Sodium } \\
(\mathrm{mg} / \mathrm{L})\end{array}$ & 36 & 67 & 63 & 29 \\
\hline $\begin{array}{c}\text { Chloride } \\
(\mathrm{mg} / \mathrm{L})\end{array}$ & 11 & 16 & 19 & 7 \\
\hline $\begin{array}{l}\text { Sulfate } \\
(\mathrm{mg} / \mathrm{L})\end{array}$ & 297 & 704 & 772 & 3420 \\
\hline $\begin{array}{c}\text { Organic Nitrogen } \\
(\mathrm{mg} / \mathrm{L})\end{array}$ & 73 & 29 & 29 & 5 \\
\hline
\end{tabular}


Table 10. Surface water runoff quality (10-30-2017)

\begin{tabular}{|c|c|c|c|c|}
\hline & Plot 1 60/40 & Plot 2 80/20 & Plot 3 Refuse & Channel \\
\hline $\begin{array}{l}\text { Sample Volume } \\
\text { (gal) }\end{array}$ & 4.5 & 4.5 & 3.5 & 1.5 \\
\hline $\begin{array}{c}\text { Temperature } \\
\left({ }^{\circ} \mathrm{C}\right)\end{array}$ & 5.6 & 4.7 & 5.7 & 0.9 \\
\hline $\mathrm{pH}$ & 6.6 & 4.2 & 4.4 & 1.3 \\
\hline $\begin{array}{l}\text { Conductivity } \\
(\mu \mathrm{s} / \mathrm{cm})\end{array}$ & 517 & 511 & 687 & 770 \\
\hline $\begin{array}{l}\text { Total Dissolved } \\
\text { Solids }(\mathrm{g} / \mathrm{L})\end{array}$ & 0.5 & 0.5 & 0.7 & 0.9 \\
\hline $\begin{array}{l}\text { Dissolved Oxygen } \\
(\mathrm{mg} / \mathrm{L})\end{array}$ & 16 & 11 & 8 & 18 \\
\hline $\begin{array}{c}\text { Aluminum } \\
(\mathrm{mg} / \mathrm{L})\end{array}$ & 115 & 38 & 59 & 96 \\
\hline $\begin{array}{l}\text { Calcium } \\
(\mathrm{mg} / \mathrm{L})\end{array}$ & 309 & 180 & 271 & 344 \\
\hline $\begin{array}{c}\text { Iron } \\
(\mathrm{mg} / \mathrm{L})\end{array}$ & 1130 & 299 & 459 & 113 \\
\hline $\begin{array}{l}\text { Magnesium } \\
(\mathrm{mg} / \mathrm{L})\end{array}$ & 46 & 20 & 29 & 53 \\
\hline $\begin{array}{l}\text { Manganese } \\
(\mathrm{mg} / \mathrm{L})\end{array}$ & 2.6 & 0.9 & 1.4 & 12 \\
\hline $\begin{array}{l}\text { Sodium } \\
(\mathrm{mg} / \mathrm{L})\end{array}$ & 30 & 24 & 30 & 14 \\
\hline $\begin{array}{c}\text { Chloride } \\
\text { (mg/L) }\end{array}$ & 9.3 & 4.6 & 8.4 & 2.6 \\
\hline $\begin{array}{l}\text { Sulfate } \\
(\mathrm{mg} / \mathrm{L})\end{array}$ & 337 & 324 & 501 & 2040 \\
\hline $\begin{array}{c}\text { Organic Nitrogen } \\
(\mathrm{mg} / \mathrm{L})\end{array}$ & 224 & 63 & 76 & 5 \\
\hline
\end{tabular}


Table 11. Surface water runoff quality (12-20-2017)

\begin{tabular}{|c|c|c|}
\hline & Plot $160 / 40$ & Plot 2 80/20 \\
\hline $\begin{array}{c}\text { Aluminum } \\
(\mathrm{mg} / \mathrm{L})\end{array}$ & 1.4 & 0.6 \\
\hline $\begin{array}{c}\text { Calcium } \\
(\mathrm{mg} / \mathrm{L})\end{array}$ & 166 & 152 \\
\hline $\begin{array}{c}\text { Iron } \\
(\mathrm{mg} / \mathrm{L})\end{array}$ & 11 & 6.5 \\
\hline $\begin{array}{c}\text { Magnesium } \\
(\mathrm{mg} / \mathrm{L})\end{array}$ & 0.2 & 0.2 \\
\hline $\begin{array}{c}\text { Manganese } \\
(\mathrm{mg} / \mathrm{L})\end{array}$ & 11 & 20 \\
\hline $\begin{array}{c}\text { Sodium } \\
(\mathrm{mg} / \mathrm{L})\end{array}$ & 337 & 300 \\
\hline $\begin{array}{c}\text { Chloride } \\
(\mathrm{mg} / \mathrm{L})\end{array}$ & 3.7 & 1.5 \\
\hline $\begin{array}{c}\text { Sulfate } \\
(\mathrm{mg} / \mathrm{L})\end{array}$ & & \\
\hline $\begin{array}{c}\text { Organic Nitrogen } \\
(\mathrm{mg} / \mathrm{L})\end{array}$ & 13 \\
\hline
\end{tabular}

With the low instance of ground cover in the test plots after recent construction, the water surface runoff quality will be low. Sediment transport will be increased with a decreasing amount of vegetation. Soils have a high erodibility when resistive forces when friction, cohesion, and adhesion, decrease because of changes caused by biological, physical, and geochemical factors contributing the soil particle bonds are lessened. When vegetation is not present, binding agents such as roots, fungus, and organic compounds will not hold the particles in place. Once vegetation is successfully established and erodibility decreases, surface runoff quality is expected to increase (Nyman et al., 2013).

These water quality data are preliminary because the methods used to collect the samples are being improved. Little conclusions can be drawn from the current set of water quality data. Therefore, monitoring and analysis continues.

\subsubsection{Soil Data}

Soil samples were collected on October 11, 2017 after completion of the test plots and seeding. Plots 1 and 2 had a small amount of ground cover, approximately $4 \%$ and $12 \%$. According to Table 12, the $\mathrm{pH}$ of each of the samples were similar, ranging from 7.1 to 7.5 , a 
value higher than expected for the refuse. From prior testing, the plot 3 refuse sample displayed uncharacteristic values (i.e. $\mathrm{pH}, \mathrm{P}, \mathrm{Mg}, \mathrm{Ca}$, and $\mathrm{Na}$ ), therefore data from sampling before site disturbance and construction was included.

Table 12. Soil data summary

\begin{tabular}{|c|c|c|c|c|}
\hline & Plot $160 / 40$ & Plot 2 80/20 & Plot 3 Refuse & $\begin{array}{c}\text { Pre-disturbance } \\
\text { Refuse }\end{array}$ \\
\hline $\mathrm{pH}$ & 7.4 & 7.5 & 7.1 & 4.5 \\
\hline $\begin{array}{c}\text { Organic Matter } \\
(\%)\end{array}$ & 10.7 & 13.0 & 11.8 & 16.0 \\
\hline $\begin{array}{l}\text { Nitrogen } \\
\text { (ppm) }\end{array}$ & 3.0 & 1.0 & 1.0 & 1.8 \\
\hline $\begin{array}{c}\text { Phosphorous } \\
\text { (ppm) }\end{array}$ & 97 & 141 & 157 & 22 \\
\hline $\begin{array}{c}\text { Potassium } \\
\text { (ppm) }\end{array}$ & 79 & 92 & 64 & 40 \\
\hline $\begin{array}{c}\text { Iron } \\
(\mathrm{ppm})\end{array}$ & 42 & 54 & 32 & 100 \\
\hline $\begin{array}{l}\text { Magnesium } \\
\text { (ppm) }\end{array}$ & 88 & 102 & 78 & 19 \\
\hline $\begin{array}{l}\text { Calcium } \\
\text { (ppm) }\end{array}$ & 2950 & 3303 & 2498 & 226 \\
\hline $\begin{array}{l}\text { Sodium } \\
\text { (ppm) }\end{array}$ & 78 & 97 & 53 & 4.5 \\
\hline
\end{tabular}

It is possible that some of the paper fiber became mixed with the refuse while constructing the growth layer of plots 1 and 2. Plot 3 was between the mixing area, and plots 1 and 2. For the first mixing technique, the paper fiber was transported and spread with the bulldozer blade. Inevitably, paper fiber is mixed into the refuse plot and does not leave a plain form of the refuse to sample.

\subsubsection{Surface Temperature Data}

With the dark nature of the refuse material, ground surface temperatures became a concern that it would become too warm for optimum germination, or if it would affect the growth of the grass. With the differing slope aspect of the plots, surface temperatures were expected to be different on each plot and affect vegetation growth unequally. In the first 
sampling, plot 1 was $7.9^{\circ} \mathrm{F}$ warmer than plot 2 (Table 13 ), and $11.4^{\circ} \mathrm{F}$ warmer in the second sampling.

Table 13. Surface temperature averages (10-30-2017)

\begin{tabular}{|c|c|c|}
\hline \multicolumn{3}{|c|}{ Surface Temperature $\left({ }^{\circ} \mathrm{F}\right)$} \\
\hline Plot 160/40 & Plot 2 80/20 & Plot 3 Refuse \\
\hline 61.9 & 54.0 & 58.0 \\
\hline
\end{tabular}

Table 14. Surface temperature averages (3-31-2018)

\begin{tabular}{|c|c|c|}
\hline \multicolumn{3}{|c|}{ Surface Temperature $\left({ }^{\circ} \mathrm{F}\right)$} \\
\hline Plot 1 60/40 & Plot 2 80/20 & Plot 3 Refuse \\
\hline 50.3 & 38.9 & 53.9 \\
\hline
\end{tabular}

Depending on the time of the year, ground temperatures will affect the plots differently. In early spring, the higher surface temperatures would be beneficial to growth. In the peak of summer, the plots would be more prone to surface burnout. Plot $160 / 40$ stands a greater chance because of the slope aspect causing a longer period of sun exposure. Figure 43 shows snow melt is more rapid on plot 1 . 


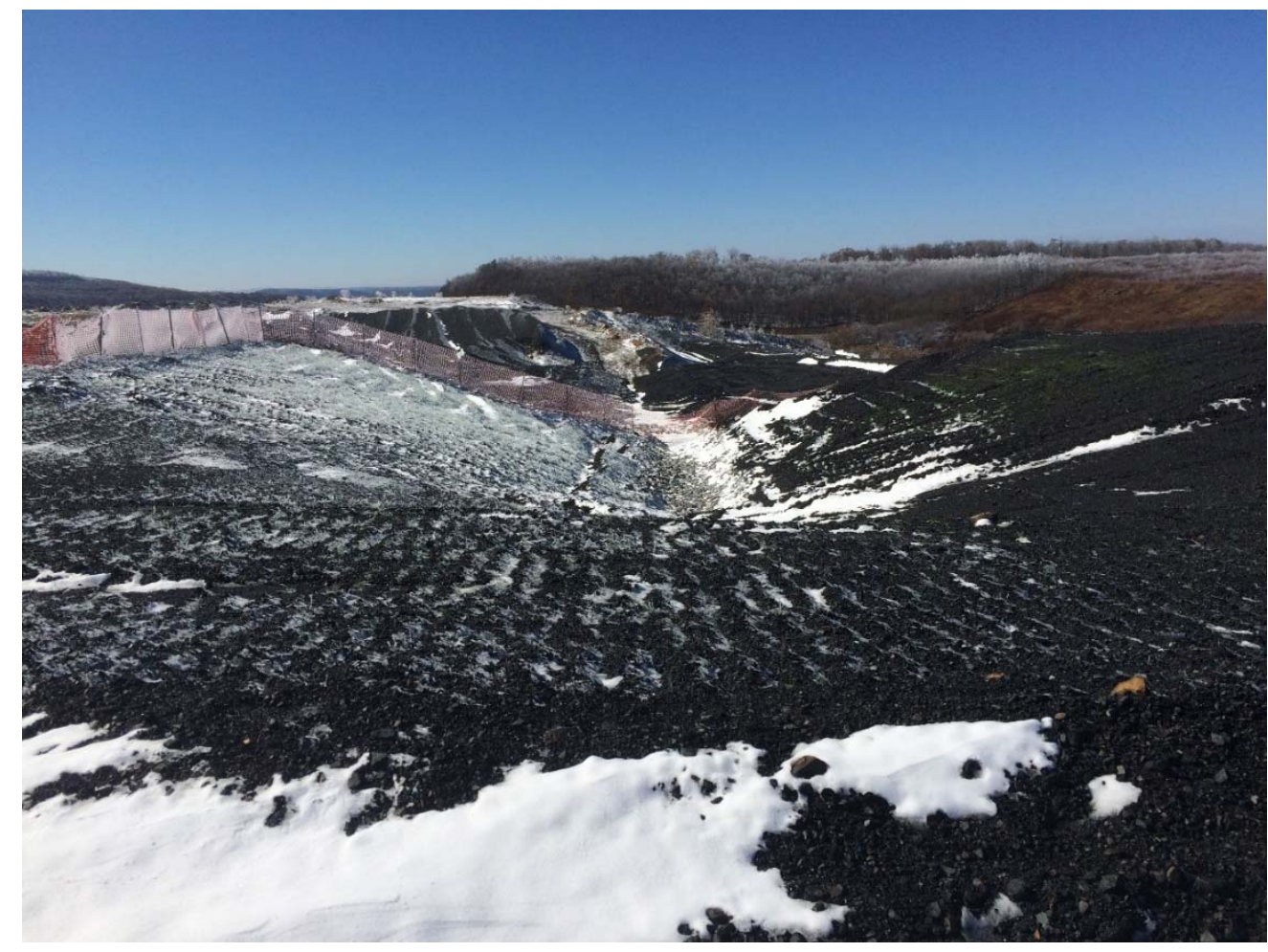

Figure 43. Snow melt showing evidence of unequal surface temperatures

\subsection{Growth Layer Performance Evaluation}

The addition of the $\mathrm{MGro}^{\mathrm{TM}}$ short paper fiber to the coal refuse created an environment that was capable of producing a balanced growth media for growing a grass-legume mixture. As the site specific mixture may help in the long term success of the vegetation of the growth layer, the paper fiber supplied the necessary nutrients needed to initially establish some vegetation.

The paper fiber provided the factors necessary to allow seed germination and plant growth. The addition of organic matter into the refuse provides an increased water holding capacity compared to the sand like material of the growth layer, while also adding fertility and providing nitrogen storage necessary for plant longevity (Coppin and Richards, 1990; Brady and Weil, 2002; Daniels and Zipper, 2010). Organic matter of the 60/40 plot was $10.7 \%$, and $13.0 \%$ in the $80 / 20$ plot, higher than the expected range. Productive soils generally range from $0.5 \%$ to $10 \%$, but increases in organic matter are related to improvements in the health of the soil (AgSource, 2017).

Refuse prior to the addition of paper fiber was too acidic for most vegetation to grow at a $\mathrm{pH}$ of 4.5. Soil $\mathrm{pH}$ for the $60 / 40 \mathrm{plot}(\mathrm{pH}=7.4)$ and $80 / 20 \mathrm{plot}(\mathrm{pH}=7.5)$ are slightly basic, 
although the best conditions for growth are slightly acidic ( $\mathrm{pH}=6.0$ to 7.0$)$ (Daniels and Zipper, 2010; AgSource, 2017).

Major nutrients such as nitrogen, phosphorous, and potassium must be available for plant growth. According to Coppin and Richards (1990), nitrogen should be greater than $0.05 \%$, phosphorous greater than $27 \mathrm{ppm}$, and potassium greater than $180 \mathrm{ppm}$. Nitrogen and phosphorous exceed the minimum values for both of plots, but fall short for potassium at $79 \mathrm{ppm}$ in the $60 / 40$ plot, and $92 \mathrm{ppm}$ in the $80 / 20$ plot.

Nitrogen should be available to plants at 75 to 150 pounds per acre on mine soils, but not exceeding 150 pounds to avoid suppressing legume development. In previous studies, plant available nitrogen in mine soils is taken up at $19 \%$, and nitrogen is present in $\mathrm{MGro}^{\mathrm{TM}}$ paper fiber residuals at 1.3\% (Daniels et al., 2013; Daniels and Zipper, 2010; WestRock, personal communication). Therefore, plot 1 containing $60 \%$ refuse and $40 \%$ paper fiber supplied nitrogen at 3945 pounds per acre, 26 times the maximum recommended amount. Only accounting for nitrogen in calculating an application rate, paper fiber would be applied at a minimum of 30,400 pounds per acre. Growth layer mixing proportions could then be $2.8 \%$ paper fiber to $97.2 \%$ refuse.

Grasses have a large tolerance for temperatures for growth and development, ranging from $40^{\circ} \mathrm{F}$ to $105^{\circ} \mathrm{F}$, but optimum temperatures of the chosen seeding mixture is between $68^{\circ} \mathrm{F}$ and $77^{\circ} \mathrm{F}$ (Beard, 1973). In the climate area and high elevations of the project site, winter temperatures will be below $40^{\circ} \mathrm{F}$ and seeds experience little biological activity in the winter, as seen by the complete loss of vegetation from October to March. In the time of data collection from September until April, the site did not experience severe upper temperatures, but may in summer months at the surface with the dark nature of the material. The site was mulched at the same time as seeding to aid in lowering surface temperatures, but was no longer present at the start of the growing season in 2018, when ground cover was back to near zero.

Temperatures will vary throughout seasons but surface temperatures also varied across plots. Plot 1 60/40 experienced higher temperatures than plot 2 80/20. Regardless of the surface temperature and slope aspect difference, vegetation ground cover was greater in plot 2, 80/20 blend. This trend in results was also seen in small-scale vegetation testing of the same paper refuse blends, with no difference in slope aspect or surface temperature (Cyphers et al., 2018). 


\section{Conclusion}

The test plots should be monitored for a greater length of time to ensure the long-term performance of the cap and cover design. This portion of monitoring spanned only seven months, from September 2017 until March 2018. As it has been shown in Chapter 4, both blends were able to establish vegetation, which is the main goal of the growth layer. Neither plot was able yet to reach $70 \%$ ground cover, the minimum needed for release of the NPDES permit.

In the short duration of monitoring, plot $280 / 20$ outperformed plot $160 / 40$, with the lower content of paper fiber used in the growth layer. Despite having a lower paper fiber content, plot 2 did not suffer large nutrient deficiencies from plot 1 other than nitrogen. As the test plots are currently configured, ground cover vegetation of plot 2 exceeded plot 1 by more than $20 \%$. To test the influence of slope aspect and surface temperatures on the vegetation performance, the plots should have been split in half vertically and tested both blends on each side of the plots.

It is difficult to draw conclusions from the surface water quality data without a higher percentage of ground cover. Water quality will be worse directly after construction, when no vegetation has been established, than after long term vegetation. Roots hold soil particles in place and are not as likely to mobilize when introduced to water. If the runoff water does not improve with increased ground cover, it will need captured and treated before discharging.

Without being able to compact the refuse with a roller, the hydraulic barrier will not perform as well as designed. Compaction did not meet the $95 \%$ of optimum required and therefore the rate of infiltration suffered. Infiltration was expected to be four orders of magnitude less than what was produced in the field. If unable to operate a roller safely on all areas of the full reclamation, the bulldozer operator will have to give special attention to the steeper areas to track in every part of the material, at lifts of no more than $8 \mathrm{in}$.

Mixing the material for the growth layer may turn out to be a time consuming process, but it needs to be performed thoroughly to have success in establishing and maintaining vegetation. The growth layer should be mixed before placement, or it may be spread first and then mixed with a large tiller that is able to reach a depth of 12 in into the ground to mix the full thickness of the layer.

To aid in the success of construction, the full reclamation should begin in the dry season of the summer, and be seeded in the fall. The low compaction percentages experienced in the test plots were as a result of low compaction energy and high moisture contents. By regrading in the 
driest time of the year, compaction may be increased with a small increase in energy combined with a lower in situ moisture content. The grass mixture is to be seeded in the spring or fall, so shortly after the completion of the regrading and growth layer placement during the summer, seeding could take place in the fall if construction is finished. If that does not happen, seeding could occur in the following spring months, but should not take place in winter. 


\section{References}

AgSource, 2017. "Understanding a Soil Analysis". AgSource Laboratories. Retrieved from $<$ https://www.agsourcelaboratories.com/agronomy-agricultural-services/agricultural-soiltesting/understanding-soil\#186680-organic-matter>.

Akcil, A. and Koldas, S. (2006). “Acid Mine Drainage (AMD): causes, treatment and case studies." Journal of Cleaner Production, 14(12-13), 1139-1145.

Albright, W.H., C.H. Benson, and W.W. Joseph. (2010). Water Balance Covers for Waste Containment: Principles and Practice. American Society of Engineers, Reston, Virginia, $146 \mathrm{pp}$.

Austin, T. (1992). “Landfill-Cover Conflict”. Civil Engineering, 62(12), 70-71.

Beard, J.B. (1973). Turfgrass: Science and Culture. Prentice-Hall, Inc., New Jersey. 658 pp.

Bouazza, A. (2002). “Geosynthetic clay liners”. Geotextiles and Geomembranes, 20(2002), 3-17.

Brofas, G. and C. Varelides. (2000). "Hydro-seeding and mulching for establishing vegetation on mining spoils in Greece". Land Degradation \& Development, 11, 375-382.

Camberato, J.J., B. Gagnon, D.A. Angers, M.H. Chantigny, and W.L. Pan. (2006). "Pulp and paper mill by-products as soil amendments and plant nutrient sources". Canadian Journal of Soil Science, 86(4), 641-653.

Carpenter, A.F., and I.J. Fernandez. (2000). "Pulp Sludge as a Component in Manufactured Topsoil". Journal of Environmental Quality, 29: 387-397.

Coppin, N.F. and I.G. Richards. (1990). Use of Vegetation in Civil Engineering. CIRIA, London, UK. 310 pp.

Chong, S., Becker, M., Moore, S., and Weaver, G. (1986). "Characterization of Reclaimed Mined Land With and Without Topsoil". Journal of Environmental Quality, 15(2), 157160

Coulloudon, B., K. Eshelman, J. Gianola, N. Habich, L. Hughes, C. Johnson, M. Pellant, P. Podborny, A. Rasmussen, B. Robles, P. Shaver, J. Spehar, and J. Willoughby. (1996)."Sampling Vegetation Attributes". Interagency Technical Reference, Bureau of Land Management, Denver, Colorado.

Cyphers, L., L. Hopkinson, J. Quaranta. (2018). “Evaluating Short Paper Fiber as a Soil Amendment for Abandoned Mine Land Reclamation in West Virginia". Proceedings of the West Virginia Academy of Science, 90(2), 1-7. 
Darling, P. (2011). SME Mining Engineering Handbook, $3^{\text {rd }}$ ed. Society for Mining, Metallurgy, and Exploration, Englewood, Colorado.

Dajic, A., M. Mihajlovic, M. Jovanovic, M. Karanac, D. Stevanovic, and J. Jovanovic. (2016). "Landfill design: need for improvement of water and soil protection requirements in EU Landfill Directive”. Clean Technologies and Environmental Policy. 18(3), 753-764.

Daniels, W.L. K.C. Haering, and J.M. Galbraith. (2004). "Mine Soil Morphology and Properties in Pre- and Post- SMCRA Coal Mined Landscapes in Southwest Virginia". Proceedings America Society of Mining and Reclamation, 2004, 421-449.

Daniels, W.L. and C.E. Zipper. (2010). "Creation and Management of Productive Minesoils". Virginia Cooperative Extension Publication 460-121.

Daniels, W.L., B. Stewart, and C.E. Zipper. (2010). "Reclamation of Coal Refuse Disposal Areas". Virginia Cooperative Extension Publication 460-131.

Daniels, W.L., K. Haering, G. Evanylo, J. Burger, and M. Beck. (2013). “Suitability of MeadWestvaco Residuals for Utilization as Soil Amendments on Reclaimed Mine Lands and Native Soils". Final Report from Virginia Tech, Department of Crop \& Soil Environmental Sciences.

Das, B.M. and K. Sobhan. (2016). Geotechnical Engineering, $9^{\text {th }}$ ed. Cengage Learning, Boston, Massachusetts, 819 pp.

Eggen, T, M. Moeder, and A. Arukwe. (2010). "Municipal landfill leachates: A significant source for new and emerging pollutants". Science of the Total Environment, 408(21), 5147-5157.

Egloffstein, T.A. (2001). "Natural bentonites - influence of the ion exchange and partial desiccation on permeability and self-healing capacity of bentonites used in GCLs". Geotextiles and Geomembranes, 19(2001), 427-444.

Elzinga, C.L., D.W. Salzer, and J.W. Willoughby. (1998). "Measuring \& Monitoring Plant Populations". Technical Reference, Bureau of Land management, Denver, Colorado.

Ford, K.L. and M. Walker. (2003). Abandoned Mine Waste Repositories: Site Selection, Design, and Cost. Technical Note 410. Bureau of Land Management, National Science and Technology Center, Denver, Colorado.

Gilbert, R.B., F. Fernandez, and D.W. Horsfield. (1996). "Shear Strength of Reinforced Geosynthetic Clay Liner”. Journal of Geotechnical Engineering, 122(4), 259-266.

Gueddouda, M.K., I. Goual, B. Benabed, S. Taibi, and N. Aboubekr. (2016). "Hydraulic properties of dune sand-bentonite mixtures of insulation barriers for hazardous waste facilities". Journal of Rock Mechanics and Geotechnical Engineering, 8(2016), 541-550. 
Henrich, C. (1994)."Acid Mine Drainage: Common Law, SMRCA, and the Clean Water Act". Journal of Natural Resources \& Environmental Law, 10(2), 235-260.

Hopkinson, L.C., J.T. Lorimer, J.R. Stevens, H. Russell, J. Hause, J.D. Quaranta, P.F. Ziemkiewicz. (2017). "Geomorphic Landform Design Principles Applied to an Abandoned Coal Refuse Pile in Central Appalachia". Journal American Society of Mining and Reclamation, 6(2), 19-36.

Im, J., J.R. Jensen, R.R. Jensen, J. Gladden, J. Waugh, and M. Serrato. (2012). "Vegetation Cover Analysis of Hazardous Waste Sites in Utah and Arizona Using Hyperspectral Remote Sensing”. Remote Sensing, 4(2), 327-353.

Jacobs, J.A., J.H. Lehr, and S.M. Testa. (2014). Acid Mine Drainage, Rock Drainage, and Acid Sulfate Soils - Causes, Assessment, Prediction, Prevention, and Remediation. John Wiley \& Sons, Inc., New Jersey, 470 pp.

Kubit, O.E., C.J. Pluhar, and J.V. De Graff. (2015). "A model for prioritizing sites and reclamation methods at abandoned mines". Environmental Earth Sciences, 73(12), 79157931.

Landva, A. and D. Knowles. (1990). Geotechnics of waste fills: theory and practice. American Society for Testing and Materials. Ann Arbor, Michigan, 375 pp.

Laubenstein, J. (2004). "Beneficial Use of Short Paper Fiber (paper mill sludge) for Pollution Prevention in the Mining Industry". TAPPI Paper Summit-Spring Technical and International Environmental Conference.

Lee, G.L., and A. Jones-Lee. (2004). "Superfund site remediation by landfilling - overview of landfill design, operation, closure, and postclosure issues". Remediation Journal, 14(3), $65-91$.

Lenhart, P.A., M.D. Eubanks, and S.T. Behmer. (2015). "Water stress in grasslands: dynamic responses of plants and insect herbivores". Oikos Synthesising Ecology, 124(3), 381-390.

Lorimer, J.T. (2016). "Geomorphic Landform Design Principles Applied to an Abandoned Coarse Coal Refuse Pile on Steep Terrain in Central Appalachia” Master's thesis. West Virginia University, Morgantown, West Virginia.

McFarland, M.J. (2001). Biosolids Engineering. McGraw-Hill Professional, New York, 800 pp.

Michael, P.R., Superfesky, M.J., and Uranowski, L.J. (2010). “Challenges to applying geomorphic and stream reclamation methodologies to mountaintop mining and excess spoil fill construction in steep-slope topography (E.G. Central Appalachia).” Journal American Society of Mining and Reclamation. 2010(2), 610-634. 
Novotny, V. (2003). Water Quality: Diffuse Pollution and Watershed Management. John Wiley $\&$ Sons, Inc. Hoboken, New Jersey.

Nyman, P., G.J. Sheridan, J.A. Moody, H.G. Smith, P.J. Noske, and P.N.J. Lane. (2013). "Sediment availability on burned hillslopes". Journal of Geophysical Research: Earth Surface, 118(4), 2451-2467.

Nyssen, J. and D. Vermeersch. (2010). "Slope aspect affects geomorphic dynamics of coal mining spoil heaps in Belgium". Geomorphology, 123(2010), 109-121.

Padilla, F.M. and F.I. Pugnaire. (2006). "The role of nurse plants in the restoration of degraded environments”. Frontiers in Ecology and the Environment, 4(4), 196-202.

Pandey, D.N., A.C. Chaubey, A.K. Gupta, and H. Vardhan. (2005). "Mine spoil restoration: a strategy combining rainwater harvesting and adaptation to random recurrence of droughts in Rajasthan". International Forestry Review, 7(3), 241-249.

Protection of Environment, 40 C.F.R. § 258 (2012a).

Protection of Environment, 40 C.F.R. § 264 (2012b).

Rajesh, S., and B.V.S. Viswanadham. (2011). "Hydro-mechanical behavior of geogrid reinforced soil barriers of landfill cover systems". Geotextiles and Geomembranes, 29(2011), 51-64.

Rajesh, S., Gourc, J., and Viswanadham, B. (2014). "Evaluation of gas permeability and mechanical behaviour of soil barriers of landfill cap covers through laboratory tests". Applied Clay Science, 97-98, 200-214.

Rowe, R.K. (2005). "Long-term performance of contaminant barrier systems". Geotechnique, 55(9), 631-678.

Sandholt, I., K. Rasmussen, and J. Andersen. (2002). "A simple interpretation of the surface temperature/vegetation index space for assessment of surface moisture status". Remote Sensing of Environment, 79(2002), 213-224.

Schanz, T. (2007). Experimental Unsaturated Soil Mechanics. Springer Science and Business Media, Heidelberg, Germany. 504 pp.

Skousen, J. and C.E. Zipper. (2010). "Revegetation Species and Practices". Virginia Cooperative Extension Publication 460-122.

Stevens, J. R. (2016). "Geotechnical testing and Finite Element Modeling of Geomorphic Landform Design with a Multi-Layer Cap and Cover System" Master's thesis. West Virginia University, Morgantown, West Virginia.

Ugurlu, A. (2004). “Leaching characteristics of fly ash”. Environmental Geology, 46(6/7), 890895. 
Villard, P. and L. Briancon. (2008). "Design of geosynthetic reinforcements for platforms subjected to localized sinkholes". Canadian Geotechnical Journal, 45(2), 196-209.

Rowe, R.K., and R.W.I. Brachman. (2004). “Assessment of equivalence of composite liners”. Geosynthetics International, 11(4), 273-286.

Vogel, W.G. (1981). “A Guide for Revegetating Coal Minesoils in the Eastern United States”. General Technical Report, U.S. Forest Service, Broomall, PA.

Ward, K. (2001). “A Toxic Legacy”. Charleston Gazette-Mail. http://www.wvgazettemail.com/article/20010812/ARTICLE/308129998/

West Virginia Department of Environmental Protection. (2006). "Erosion and Sediment Control Best Management Practice Manual". Charleston, WV. 


\section{Appendix}

\subsection{Infiltration Data}

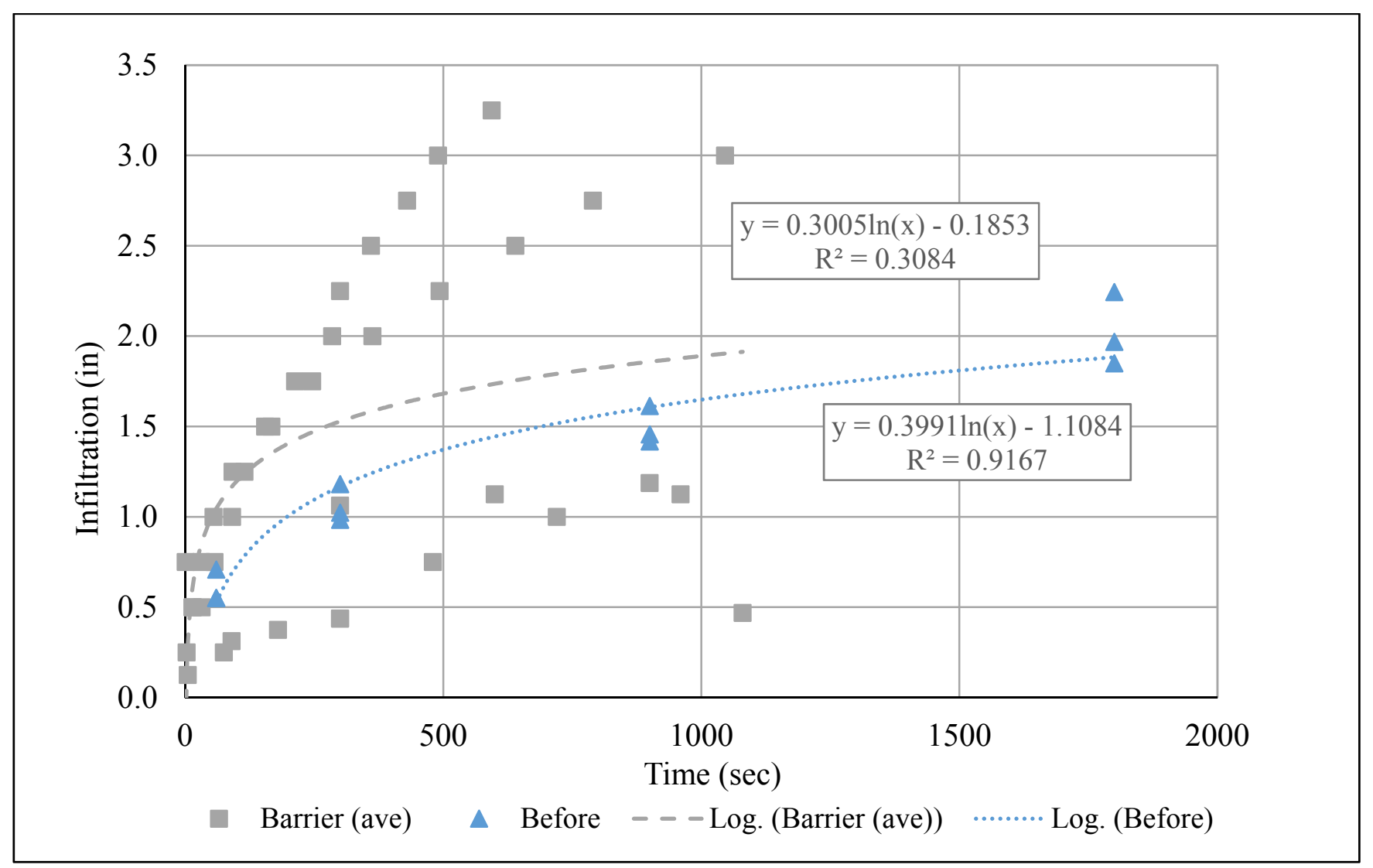

Figure 44. Infiltration of hydraulic barrier 


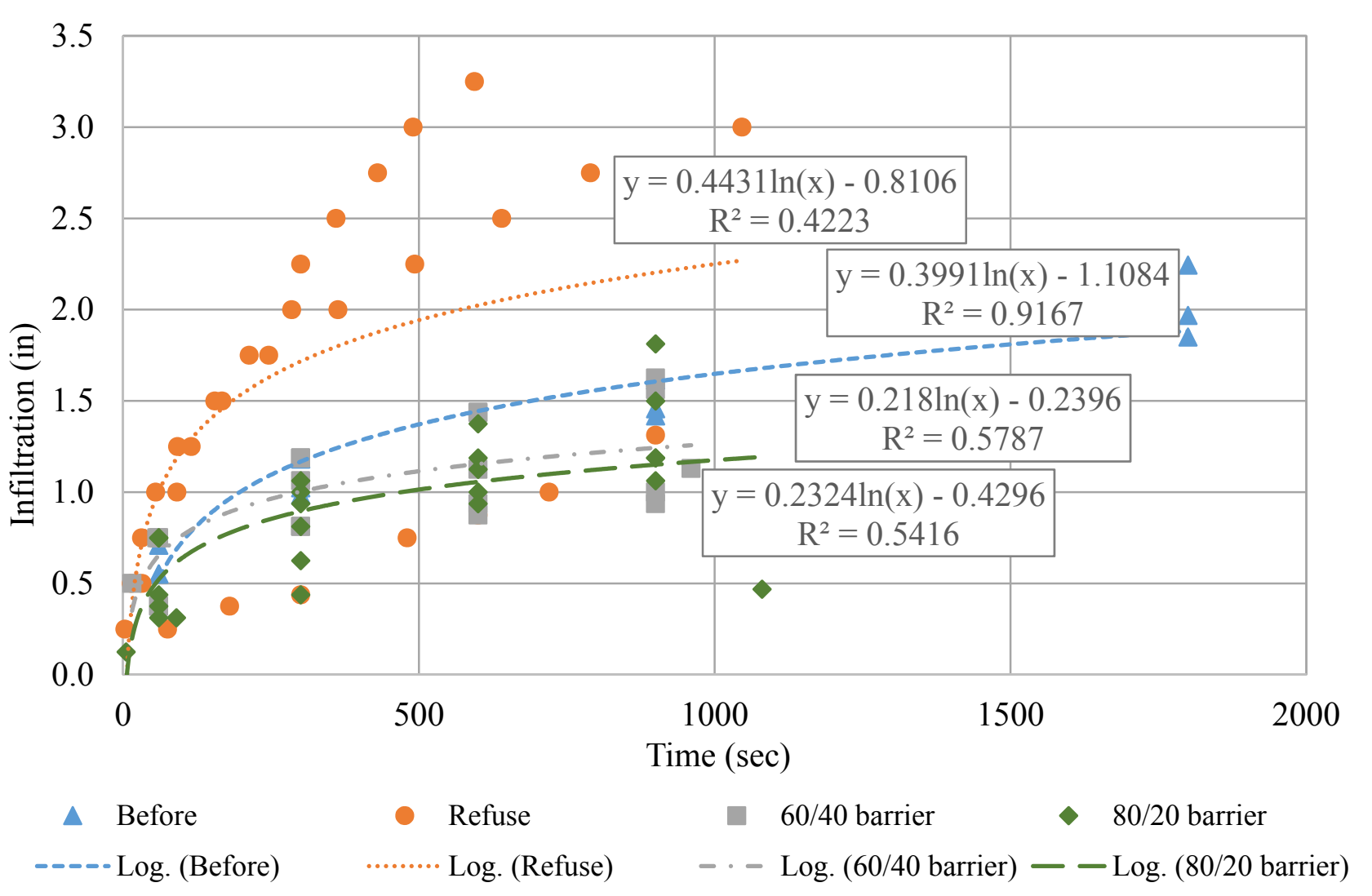

Figure 45. Infiltration of hydraulic barrier specific to each plot

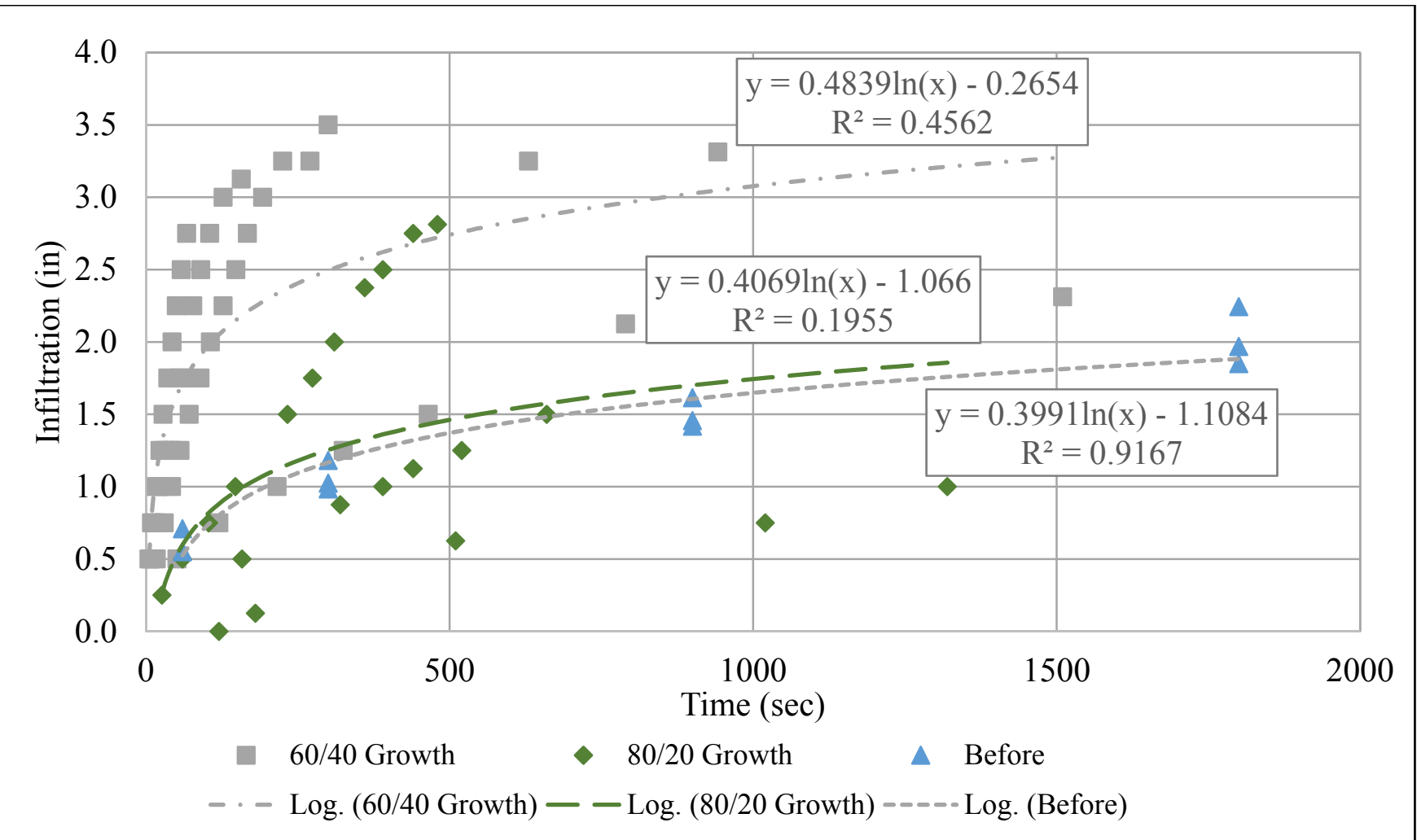

Figure 46. Infiltration of growth layers compared to pre-disturbance refuse 


\subsection{Vegetation Growth Measurements}

Sample Plot: Plot $160 / 40$

Date: 9-22-2017

\begin{tabular}{|c|c|c|c|c|c|c|c|c|c|c|c|}
\hline & A & B & & C & D & E & F & G & H & I & J \\
\hline 1 & & & & & & & & & & & \\
\hline 2 & & & & & & & & & & & \\
\hline 3 & & & & & & & & & & & \\
\hline 4 & & & & & & & & & & & \\
\hline 5 & & & & & & & & & & & \\
\hline 6 & & & & & & & & & & & \\
\hline 7 & & & & & & & & & & & \\
\hline 8 & & & & & & & & & & & \\
\hline 9 & & & & & & & & & & & \\
\hline 10 & & & & & & & & & & & \\
\hline
\end{tabular}

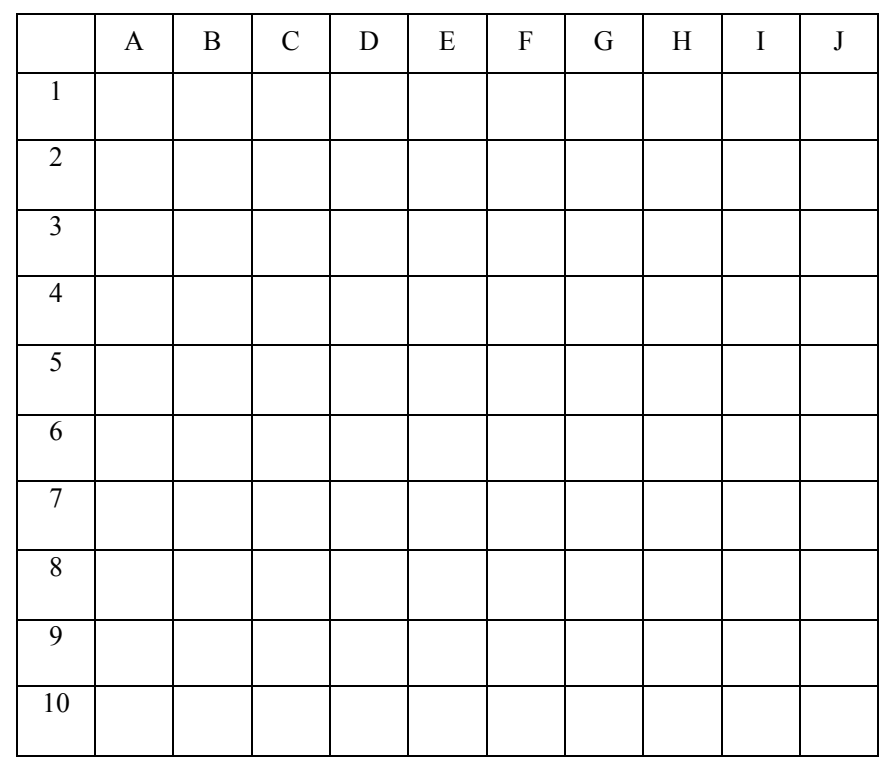

Cover $1:\left[\begin{array}{l}0 \quad \% \\ 0\end{array}\right.$

Cover $2: \quad 0 \quad \%$

Cover 3: $1 \%$

Cover $4: 1 \quad 1 \%$

Cover 5: $1 \%$

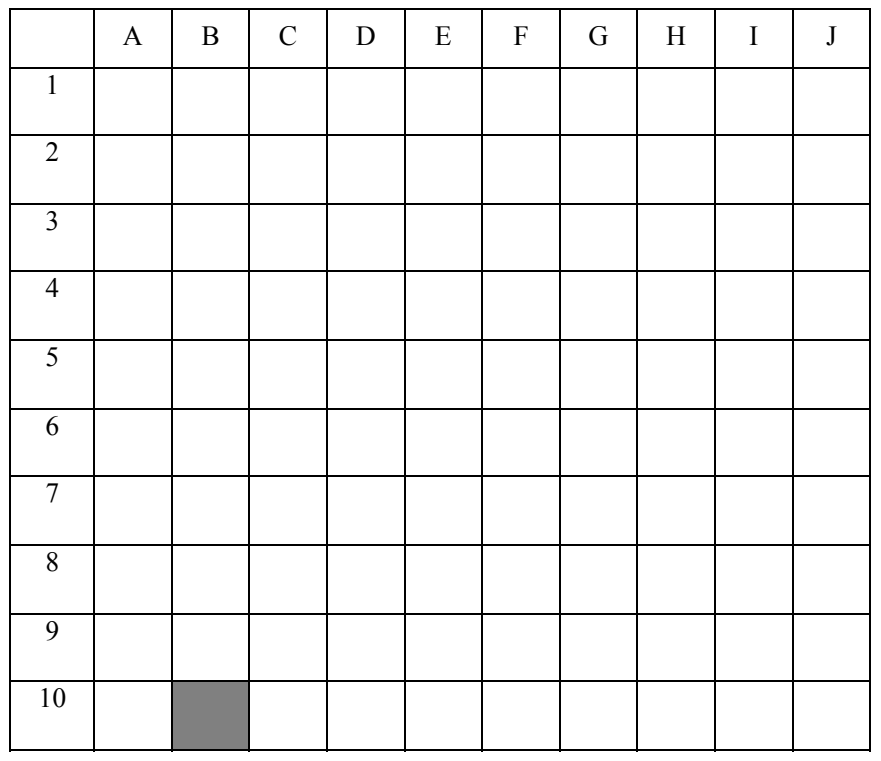

\begin{tabular}{|c|c|c|c|c|c|c|c|c|c|c|}
\hline & A & B & C & D & E & F & G & H & I & J \\
\hline 1 & & & & & & & & & & \\
\hline 2 & & & & & & & & & & \\
\hline 3 & & & & & & & & & & \\
\hline 4 & & & & & & & & & & \\
\hline 5 & & & & & & & & & & \\
\hline 6 & & & & & & & & & & \\
\hline 7 & & & & & & & & & & \\
\hline 8 & & & & & & & & & & \\
\hline 9 & & & & & & & & & & \\
\hline 10 & & & & & & & & & & \\
\hline
\end{tabular}

\begin{tabular}{|c|c|c|c|c|c|c|c|c|c|c|}
\hline & A & B & C & D & E & F & G & H & I & J \\
\hline 1 & & & & & & & & & & \\
\hline 2 & & & & & & & & & & \\
\hline 3 & & & & & & & & & & \\
\hline 4 & & & & & & & & & & \\
\hline 5 & & & & & & & & & & \\
\hline 6 & & & & & & & & & & \\
\hline 7 & & & & & & & & & & \\
\hline 8 & & & & & & & & & & \\
\hline 9 & & & & & & & & & & \\
\hline 10 & & & & & & & & & & \\
\hline
\end{tabular}


Sample Plot: Plot 2 80/20

\begin{tabular}{|c|l|l|l|l|l|l|l|l|l|l|}
\hline & $\mathrm{A}$ & $\mathrm{B}$ & $\mathrm{C}$ & $\mathrm{D}$ & $\mathrm{E}$ & $\mathrm{F}$ & $\mathrm{G}$ & $\mathrm{H}$ & $\mathrm{I}$ & $\mathrm{J}$ \\
\hline 1 & & & & & & & & & & \\
\hline 2 & & & & & & & & & & \\
\hline 3 & & & & & & & & & & \\
\hline 4 & & & & & & & & & & \\
\hline 5 & & & & & & & & & & \\
\hline 6 & & & & & & & & & & \\
\hline 7 & & & & & & & & & & \\
\hline 8 & & & & & & & & & & \\
\hline 9 & & & & & & & & & & \\
\hline 10 & & & & & & & & & & \\
\hline
\end{tabular}

Date: 9-22-2017

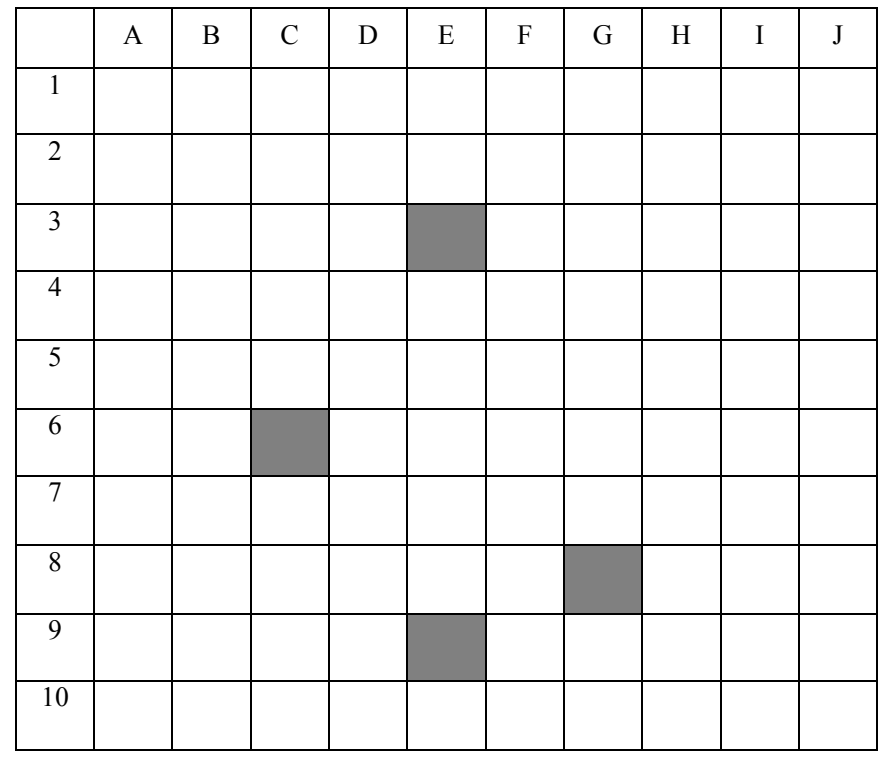

Cover $1: \underline{0} \%$

Cover $2: 4 \%$

Cover 3: $1 \%$

Cover $4: 1 \%$

Cover $5: 3 \%$

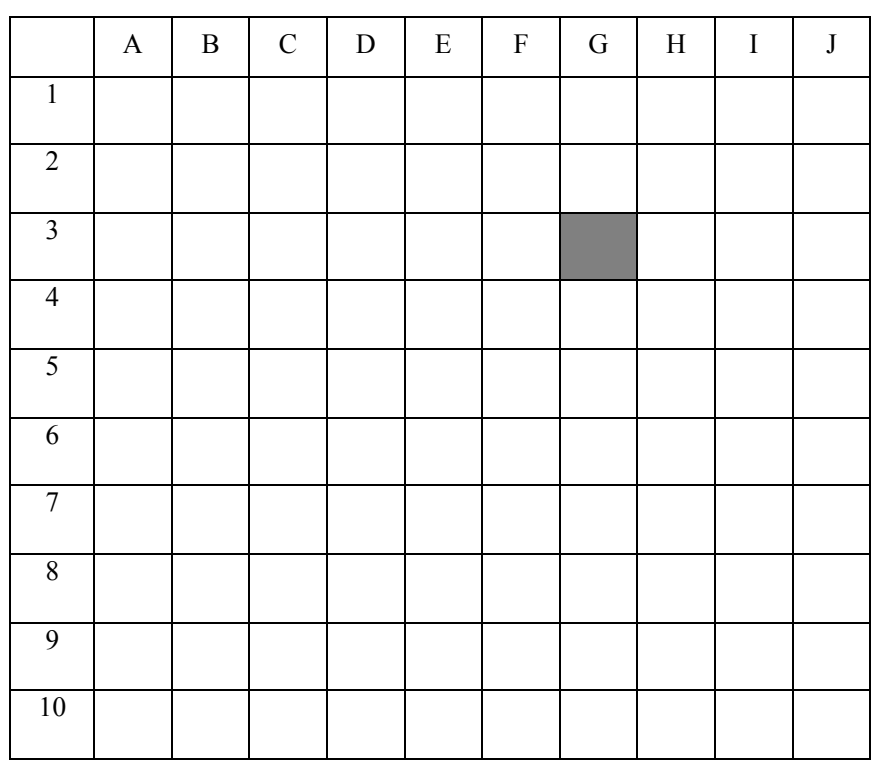

\begin{tabular}{|c|c|c|c|c|c|c|c|c|c|c|}
\hline & A & B & C & D & E & F & G & H & I & J \\
\hline 1 & & & & & & & & & & \\
\hline 2 & & & & & & & & & & \\
\hline 3 & & & & & & & & & & \\
\hline 4 & & & & & & & & & & \\
\hline 5 & & & & & & & & & & \\
\hline 6 & & & & & & & & & & \\
\hline 7 & & & & & & & & & & \\
\hline 8 & & & & & & & & & & \\
\hline 9 & & & & & & & & & & \\
\hline 10 & & & & & & & & & & \\
\hline
\end{tabular}

\begin{tabular}{|c|c|c|c|c|c|c|c|c|c|c|}
\hline & A & B & C & D & E & F & G & H & I & J \\
\hline 1 & & & & & & & & & & \\
\hline 2 & & & & & & & & & & \\
\hline 3 & & & & & & & & & & \\
\hline 4 & & & & & & & & & & \\
\hline 5 & & & & & & & & & & \\
\hline 6 & & & & & & & & & & \\
\hline 7 & & & & & & & & & & \\
\hline 8 & & & & & & & & & & \\
\hline 9 & & & & & & & & & & \\
\hline 10 & & & & & & & & & & \\
\hline
\end{tabular}


Sample Plot: Plot $160 / 40$

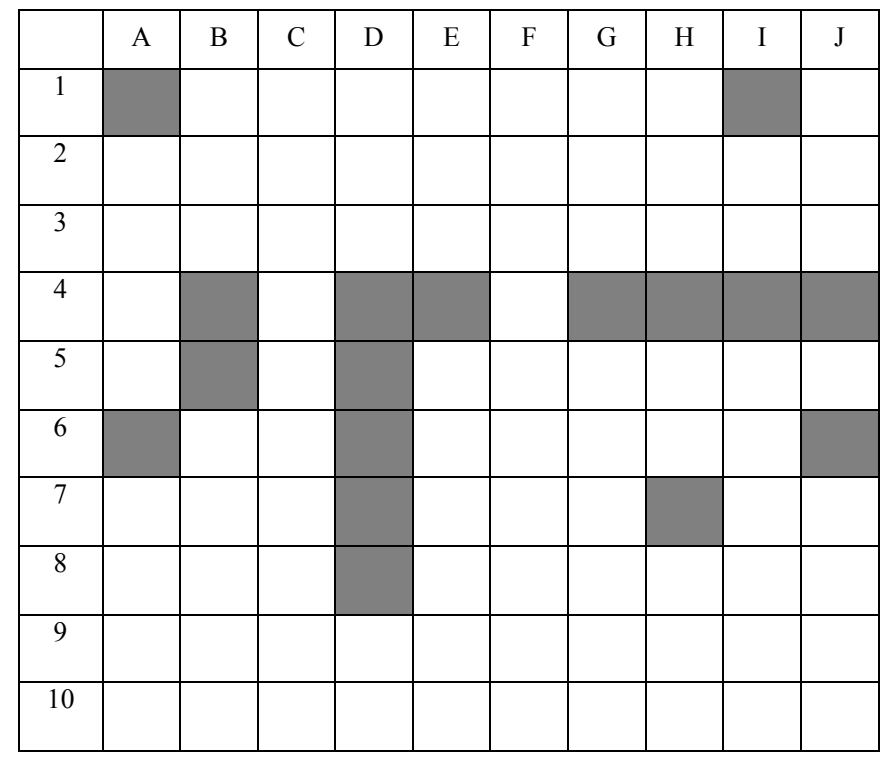

Date: 10-30-2017

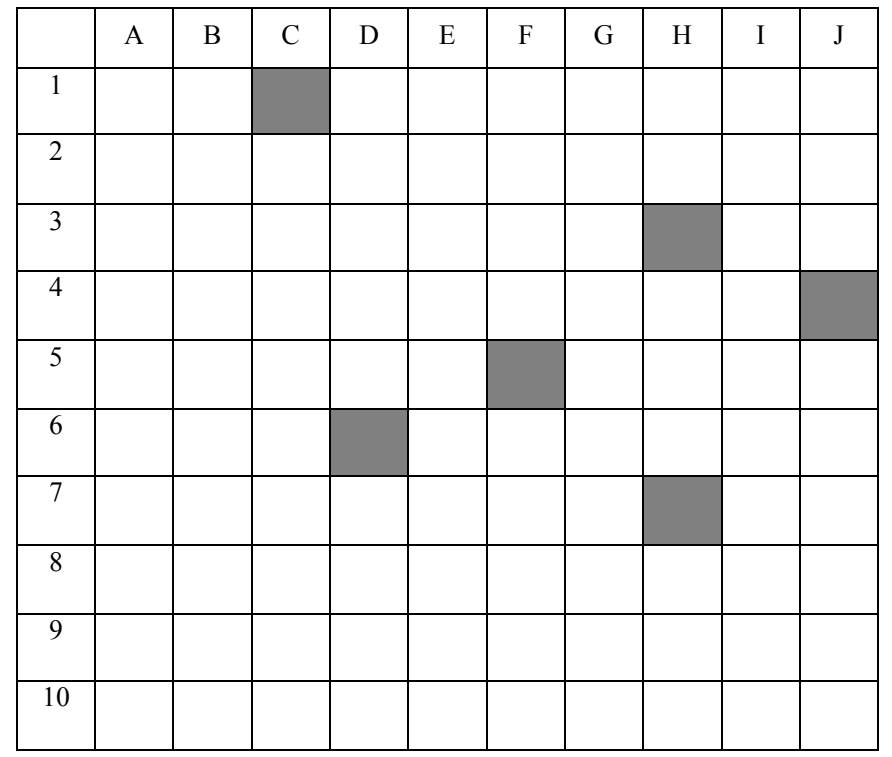

Cover 1: $18 \%$

Cover 2: $6 \%$

Cover 3: $10 \%$

Cover $4: 3 \%$

Cover $5: 2 \%$

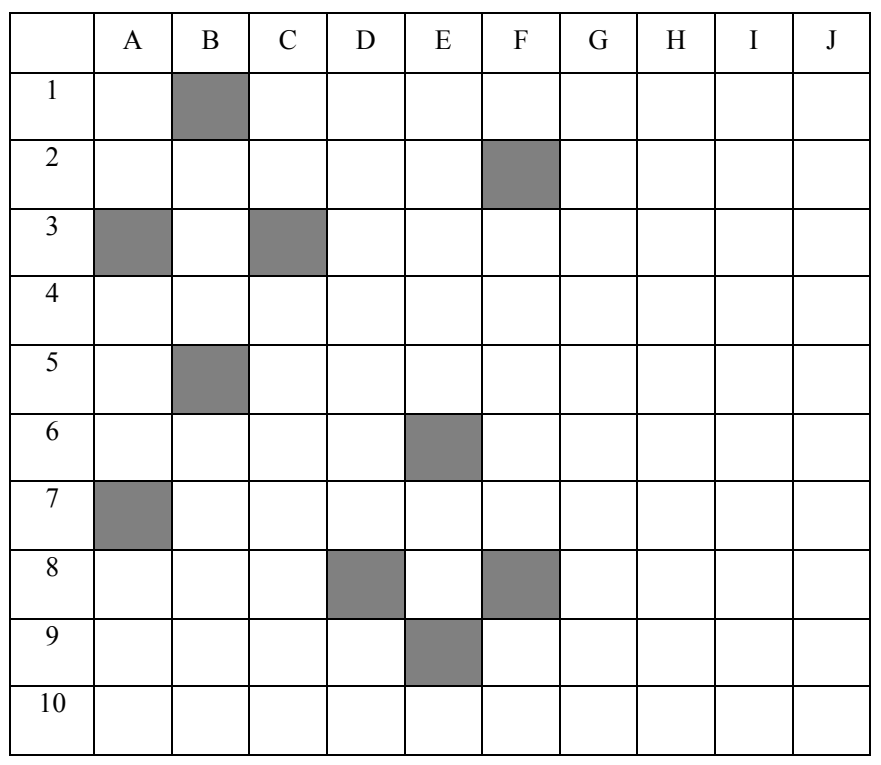

\begin{tabular}{|c|c|c|c|c|c|c|c|c|c|c|}
\hline & A & B & C & D & E & F & G & H & I & J \\
\hline 1 & & & & & & & & & & \\
\hline 2 & & & & & & & & & & \\
\hline 3 & & & & & & & & & & \\
\hline 4 & & & & & & & & & & \\
\hline 5 & & & & & & & & & & \\
\hline 6 & & & & & & & & & & \\
\hline 7 & & & & & & & & & & \\
\hline 8 & & & & & & & & & & \\
\hline 9 & & & & & & & & & & \\
\hline 10 & & & & & & & & & & \\
\hline
\end{tabular}

\begin{tabular}{|c|c|c|c|c|c|c|c|c|c|c|}
\hline & A & B & C & D & E & F & G & H & I & J \\
\hline 1 & & & & & & & & & & \\
\hline 2 & & & & & & & & & & \\
\hline 3 & & & & & & & & & & \\
\hline 4 & & & & & & & & & & \\
\hline 5 & & & & & & & & & & \\
\hline 6 & & & & & & & & & & \\
\hline 7 & & & & & & & & & & \\
\hline 8 & & & & & & & & & & \\
\hline 9 & & & & & & & & & & \\
\hline 10 & & & & & & & & & & \\
\hline
\end{tabular}


Sample Plot: Plot $280 / 20$

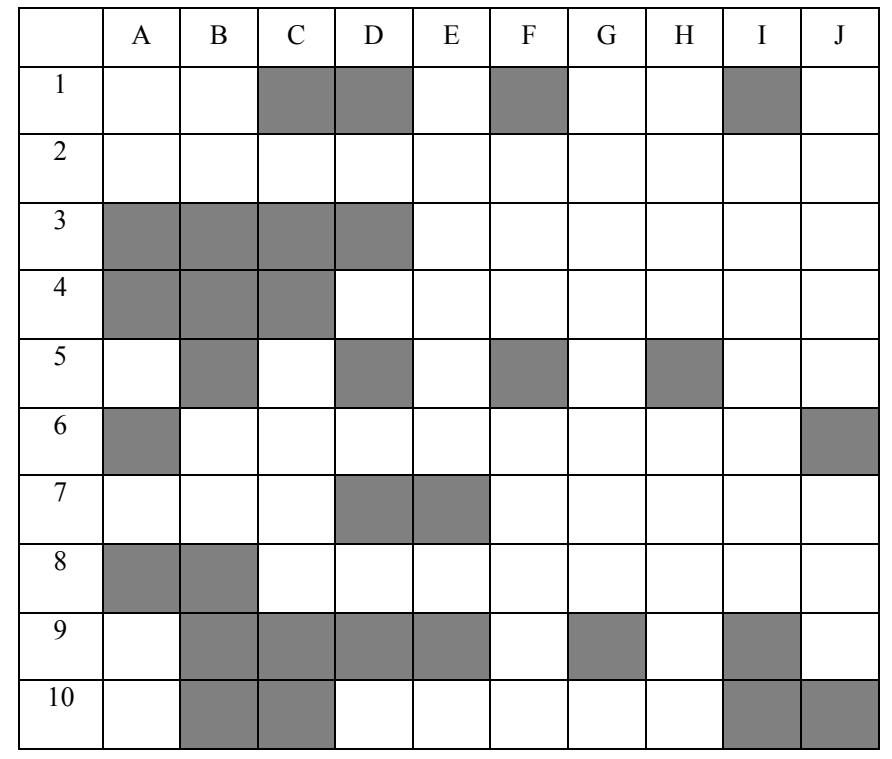

Date: $10-30-2017$

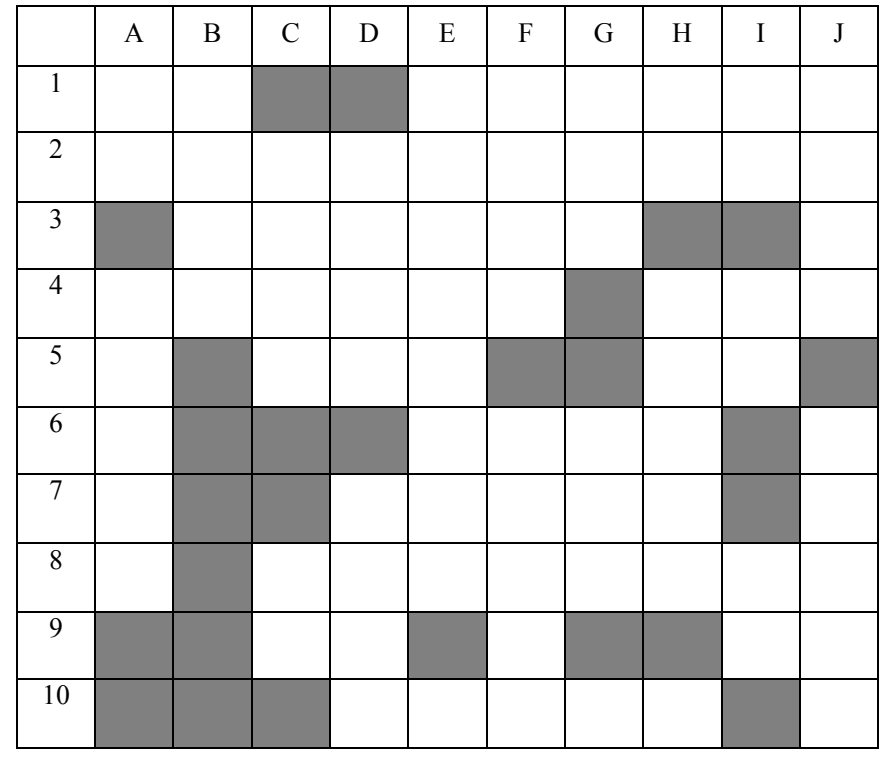

Cover 1: $31 \%$

Cover 2: $27 \%$

Cover 3: $35 \%$

Cover $4: 23 \%$

Cover $5: 31 \%$

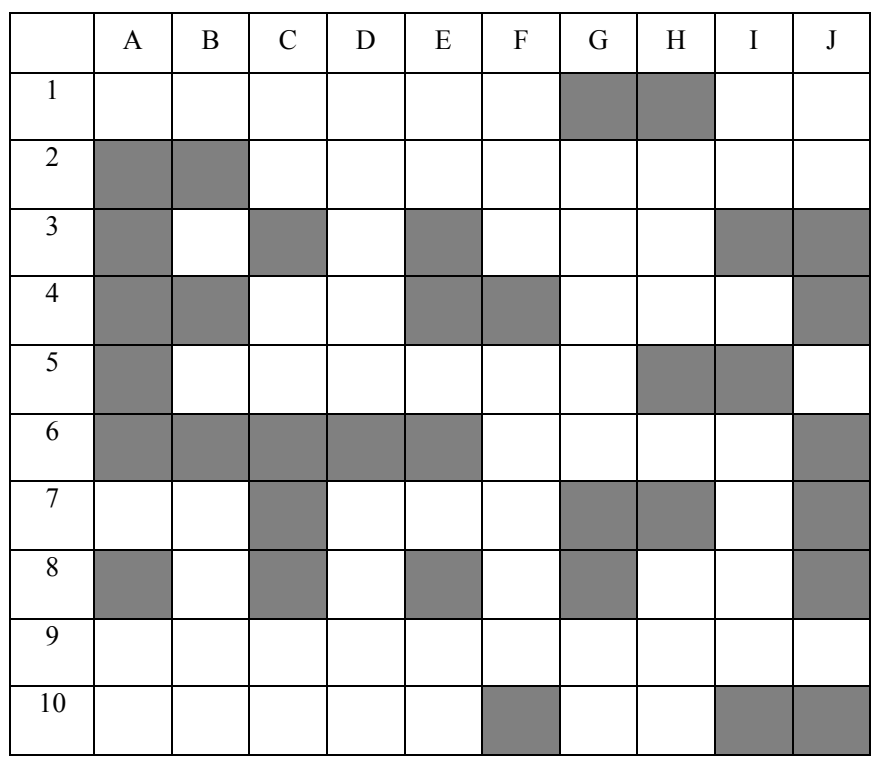

\begin{tabular}{|c|c|c|c|c|c|c|c|c|c|c|}
\hline & A & B & C & D & E & F & G & H & I & J \\
\hline 1 & & & & & & & & & & \\
\hline 2 & & & & & & & & & & \\
\hline 3 & & & & & & & & & & \\
\hline 4 & & & & & & & & & & \\
\hline 5 & & & & & & & & & & \\
\hline 6 & & & & & & & & & & \\
\hline 7 & & & & & & & & & & \\
\hline 8 & & & & & & & & & & \\
\hline 9 & & & & & & & & & & \\
\hline 10 & & & & & & & & & & \\
\hline
\end{tabular}

\begin{tabular}{|c|c|c|c|c|c|c|c|c|c|c|}
\hline & $\mathrm{A}$ & $\mathrm{B}$ & $\mathrm{C}$ & $\mathrm{D}$ & $\mathrm{E}$ & $\mathrm{F}$ & $\mathrm{G}$ & $\mathrm{H}$ & $\mathrm{I}$ & $\mathrm{J}$ \\
\hline 1 & & & & & & & & & & \\
\hline 2 & & & & & & & & & & \\
\hline 3 & & & & & & & & & & \\
\hline 4 & & & & & & & & & & \\
\hline 5 & & & & & & & & & & \\
\hline 6 & & & & & & & & & & \\
\hline 7 & & & & & & & & & & \\
\hline 8 & & & & & & & & & & \\
\hline 9 & & & & & & & & & & \\
\hline 10 & & & & & & & & & & \\
\hline
\end{tabular}


Sample Plot: Plot $160 / 40$

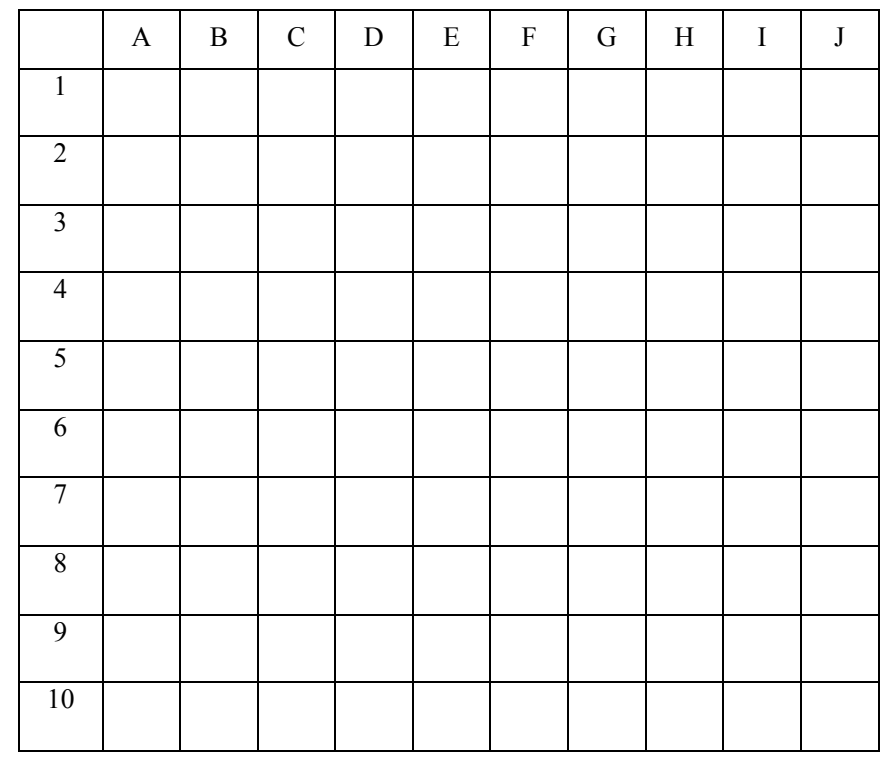

Date: $3-31-2018$

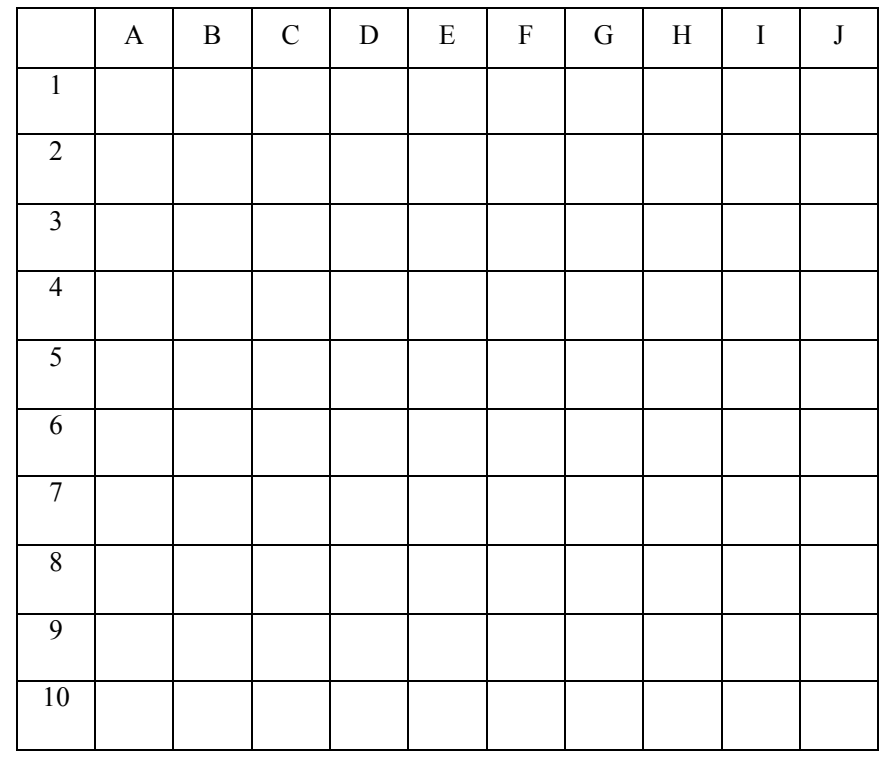

Cover 1: $0 \%$

Cover 2: $0 \quad \%$

Cover $3: 1 \quad 1 \%$

Cover $4: \quad 0 \quad \%$

Cover $5: 2 \%$

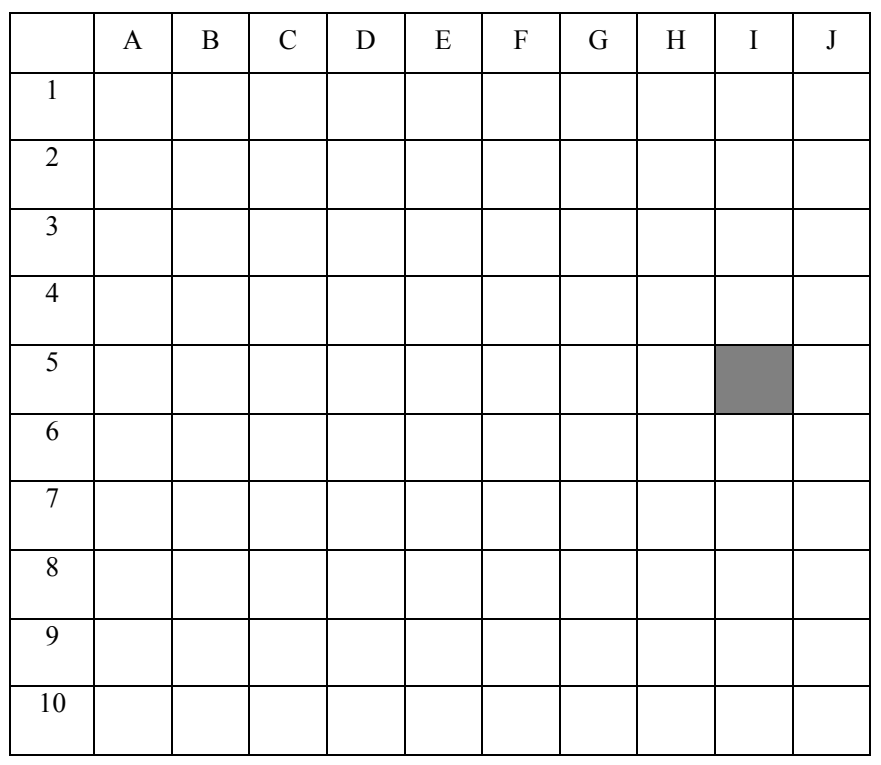

\begin{tabular}{|c|c|c|c|c|c|c|c|c|c|c|}
\hline & A & B & C & D & E & F & G & H & I & J \\
\hline 1 & & & & & & & & & & \\
\hline 2 & & & & & & & & & & \\
\hline 3 & & & & & & & & & & \\
\hline 4 & & & & & & & & & & \\
\hline 5 & & & & & & & & & & \\
\hline 6 & & & & & & & & & & \\
\hline 7 & & & & & & & & & & \\
\hline 8 & & & & & & & & & & \\
\hline 9 & & & & & & & & & & \\
\hline 10 & & & & & & & & & & \\
\hline
\end{tabular}

\begin{tabular}{|c|c|c|c|c|c|c|c|c|c|c|}
\hline & A & B & C & D & E & F & G & H & I & J \\
\hline 1 & & & & & & & & & & \\
\hline 2 & & & & & & & & & & \\
\hline 3 & & & & & & & & & & \\
\hline 4 & & & & & & & & & & \\
\hline 5 & & & & & & & & & & \\
\hline 6 & & & & & & & & & & \\
\hline 7 & & & & & & & & & & \\
\hline 8 & & & & & & & & & & \\
\hline 9 & & & & & & & & & & \\
\hline 10 & & & & & & & & & & \\
\hline
\end{tabular}


Sample Plot: $\quad$ Plot $280 / 20$

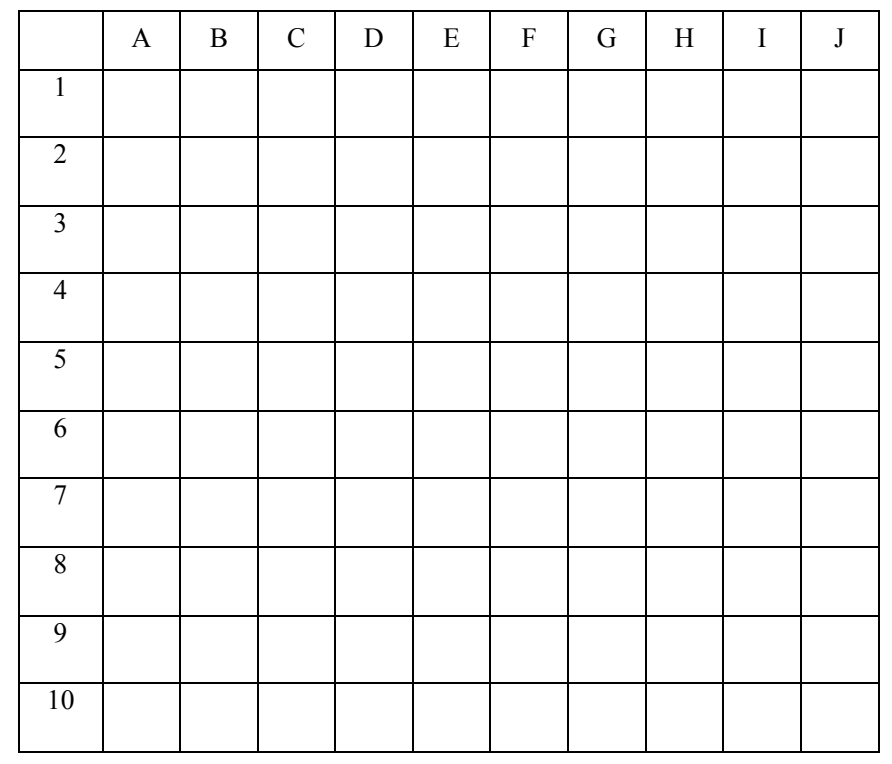

Date: $3-31-2018$

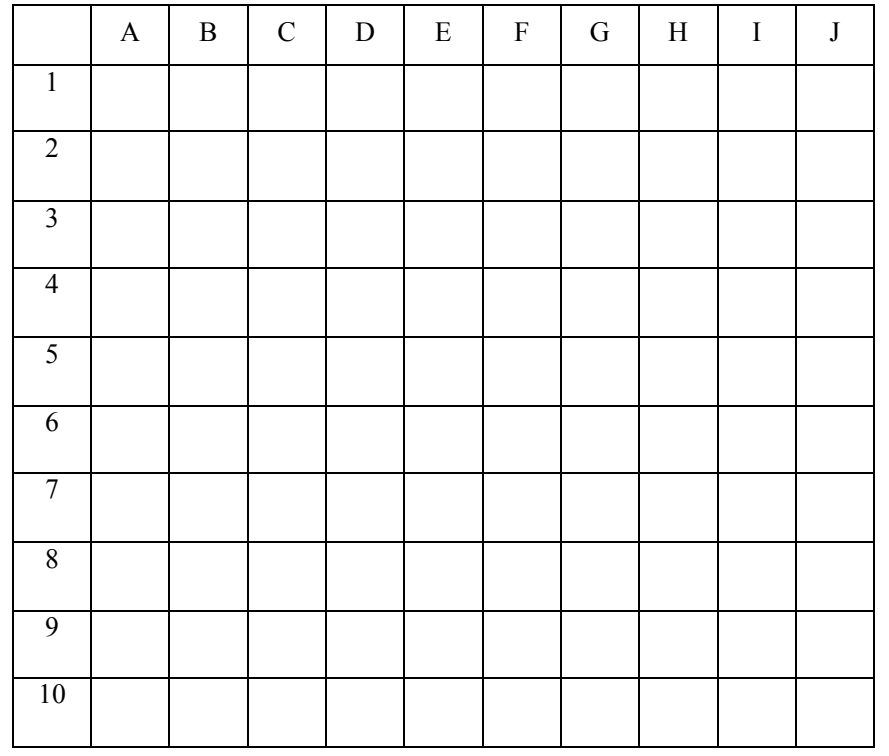

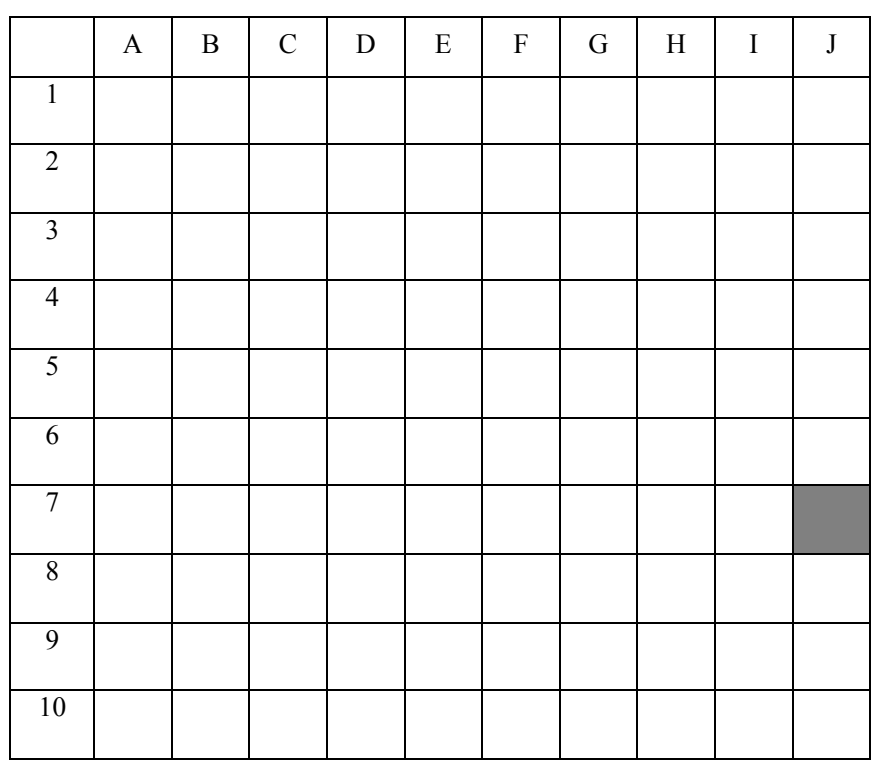

\begin{tabular}{|c|c|c|c|c|c|c|c|c|c|c|}
\hline & A & B & C & D & E & F & G & H & I & J \\
\hline 1 & & & & & & & & & & \\
\hline 2 & & & & & & & & & & \\
\hline 3 & & & & & & & & & & \\
\hline 4 & & & & & & & & & & \\
\hline 5 & & & & & & & & & & \\
\hline 6 & & & & & & & & & & \\
\hline 7 & & & & & & & & & & \\
\hline 8 & & & & & & & & & & \\
\hline 9 & & & & & & & & & & \\
\hline 10 & & & & & & & & & & \\
\hline
\end{tabular}

\begin{tabular}{|c|c|c|c|c|c|c|c|c|c|c|}
\hline & A & B & C & D & E & F & G & H & I & J \\
\hline 1 & & & & & & & & & & \\
\hline 2 & & & & & & & & & & \\
\hline 3 & & & & & & & & & & \\
\hline 4 & & & & & & & & & & \\
\hline 5 & & & & & & & & & & \\
\hline 6 & & & & & & & & & & \\
\hline 7 & & & & & & & & & & \\
\hline 8 & & & & & & & & & & \\
\hline 9 & & & & & & & & & & \\
\hline 10 & & & & & & & & & & \\
\hline
\end{tabular}


7.3. Complete Soil Data

\begin{tabular}{|c|c|c|c|c|}
\hline & Plot 1 60/40 & Plot 2 80/20 & Plot 3 Refuse & $\begin{array}{c}\text { Pre-disturbance } \\
\text { Refuse }\end{array}$ \\
\hline $\mathrm{pH}$ & 7.4 & 7.5 & 7.1 & 4.5 \\
\hline Organic Matter (\%) & 10.7 & 13.0 & 11.8 & 16.0 \\
\hline Nitrogen (ppm) & 3.0 & 1.0 & 1.0 & 1.8 \\
\hline Phosphorous (ppm) & 97 & 141 & 157 & 22 \\
\hline Potassium (ppm) & 79 & 92 & 64 & 40 \\
\hline Magnesium (ppm) & 88 & 102 & 78 & 19 \\
\hline Calcium (ppm) & 2950 & 3303 & 2498 & 226 \\
\hline Sulfur (ppm) & 294 & 275 & 225 & 88 \\
\hline Zinc (ppm) & 1.0 & 1.5 & 0.9 & 0.3 \\
\hline Manganese (ppm) & 5.1 & 8.3 & 3.7 & 1.0 \\
\hline Copper (ppm) & 1.5 & 2.2 & 1.5 & 1.3 \\
\hline Iron (ppm) & 42 & 54 & 32 & 100 \\
\hline Boron (ppm) & 0.2 & 0.3 & 0.2 & 0.1 \\
\hline Sodium (ppm) & 78 & 97 & 53 & 5 \\
\hline Soluble Salts & 1.13 & 1.09 & 0.87 & 0.36 \\
\hline
\end{tabular}

